\title{
UTILIZAÇÃO DE TOMOGRAFIA POR RESSONÂNCIA MAGNÉTICA NUCLEAR PARA SEXAGEM DE AVES SILVESTRES SEM DIMORFISMO SEXUAL
}

\author{
Angélica Paula Grando
}

Dissertação apresentada ao Programa de PósGraduação Interunidades em Bioengenharia Escola de Engenharia de São Carlos / Faculdade de Medicina de Ribeirão Preto / Instituto de Química de São Carlos da Universidade de São Paulo, para obtenção do título de Mestre em Bioengenharia.

ORIENTADOR: Dr. Rubens Bernardes Filho

São Carlos

2002 


\title{
Ser veterinário
}

Pensando bem...ser veterinário não é só cuidar de animais.

É, sobretudo, amá-los, não ficando somente nos padrões éticos de uma ciência médica.

Ser veterinário é acreditar na imortalidade da natureza e querer preservá-la sempre mais bela.

Ser veterinário é ouvir miados, mugidos, balidos, relinchos e latidos, mas principalmente entendê-los e amenizá-los.

É gostar de terra molhada, de mato fechado, de luas e chuvas.

Ser veterinário é não importar se os animais pensam, mas sim sofrem.

É dedicar parte do seu ser à arte de salvar vidas.

Ser veterinário é aproximar-se de instintos.

É perder medos.

É ganhar amigos de pêlos e penas, que jamais irão decepcioná-lo.

Ser veterinário é ter ódio de gaiolas, jaulas e correntes.

É perder um tempo enorme apreciando rebanhos e vôos de gaivotas.

É permanecer descobrindo através de animais, a si mesmo.

Ser veterinário é o único capaz de entender rabos abanando, arranföes carinhosos e mordidas de afeto.

É sentir cheiro de pêlo molhado, cheiro de almofada com essência de gato, cheiro de baias, de curral, de esterco.

Ser veterinário é ter coragem de penetrar em um mundo diferente, e ser igual.

É ter capacidade de compreender gratidões mudas, mas sem dúvida alguma, as únicas verdadeiras.

É aliviar olhares, é lembrar do seu tempo de criança, querer levar para casa todos os cães vadios sem dono.

Ser veterinário é conviver lado a lado com ensinamentos profundos de amor e vida. "Todos nós podemos nos formar em veterinária, mas nem todos seremos veterinários".

(Autor desconhecido)

\author{
Aos animais deste estudo, \\ toda minha gratidão e respeito.
}


Dedico este trabalho à Amélia e Francisco. A meus pais, que contribuíram de forma decisiva para minha formação profissional, minha eterna gratidão e amor. 
Agradecimentos especiais

Ao Programa de Pós-Graduação Interunidades em

Bioengenharia - EESC / FMRP / IQSC - USP e à Embrapa

Instrumentação Agropecuária, pela oportunidade de realização deste

trabalho.

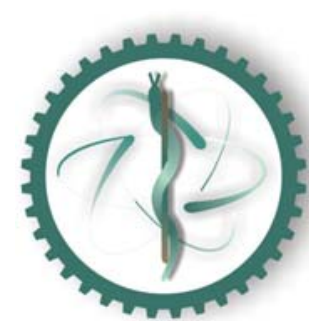

BIOENGENHARIA

USP

\section{Embrapa}

Instrumentação Agropecuária 


\section{Agradecimentos}

Ao meu orientador, Dr. Rubens Bernardes Filho, pelo apoio, incentivo e orientação dispensada.

Ao Prof. Dr. Orivaldo Lopes da Silva, pelo apoio, sugestões e por me estender a mão quando mais precisei.

Ao Dr. Roberto Weider de Assis Franco, pela amizade, paciência e ensinamentos indispensáveis para a realização deste trabalho.

A Fernando S. Magnani, Ana Rita C. Salles, Francisco Rogério Paschoal e toda a equipe do Parque Ecológico Antonio T. Vianna, São Carlos, por fornecerem os animais deste estudo e pelo grande auxílio prestado.

A André Luís Paschoal, pelo apoio e incentivo nos momentos difíceis.

Ao Médico Veterinário Antônio Pereira de Novaes, pelo auxílio prestado na etapa inicial deste trabalho.

A CITOCEL Laboratório em Genética, pelo material e exame de sexagem fornecidos.

Aos amigos professores, funcionários e pós-graduandos do Programa de Pós-Graduação Interunidades em Bioengenharia - EESC/FMRP/IQSC-USP.

À CAPES, pelo apoio financeiro.

À Lauralice de Campos F. Canale, por me acolher quando precisei.

A César Augusto, do IOT-FMUSP, pelo auxílio neste trabalho e pela amizade de tantos anos. 
Às Profas. Dras. Arani N. B. Mariana e Silvia R. G. Cortopassi, da FMVZ-USP, pelas informações sobre anatomia e anestesia de aves.

À Vera Octaviano, pelo auxílio gramatical nesta dissertação.

A toda minha família, pelo carinho, apoio e incentivo. 


\section{Sumário}

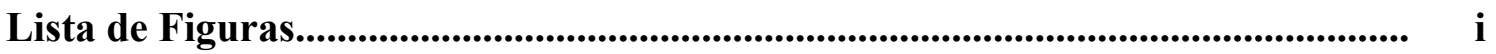

Lista de Tabelas............................................................................................. iv

Lista de Abreviaturas e Siglas....................................................................................... v

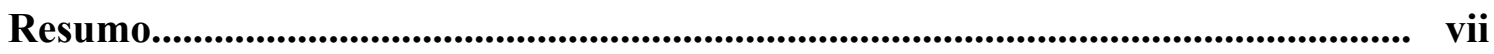

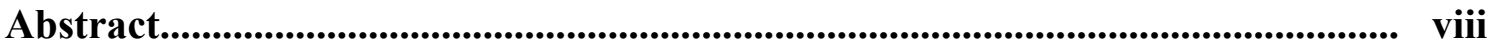

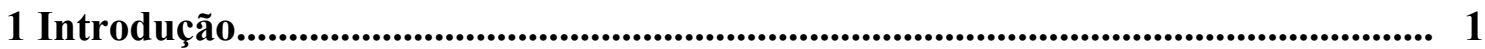

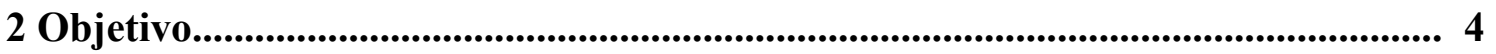

3 Revisão da Literatura.......................................................................................... 5

3.1 Sexagem de Aves Monomórficas................................................................... 5

3.2 Revisão Anatômica........................................................................................8

3.2.1 Sistema Reprodutor Masculino.......................................................... 8

3.2.2 Sistema Reprodutor Feminino................................................................... 11

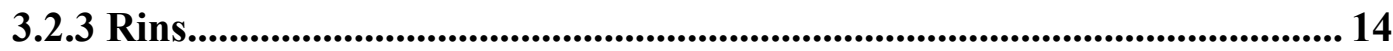

3.2.4 Glândulas Adrenais........................................................................................ 14

3.3 A Ressonância Magnética Nuclear (RMN)....................................................15

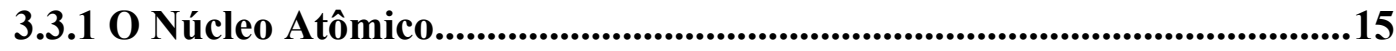

3.3.2 O Fenômeno de Ressonância.................................................................... 18

3.3.2.1 Relaxação......................................................................................................20

3.3.3 Seqüências de Pulso.............................................................................21

3.3.4 Tomografia por Ressonância Magnética Nuclear - TRMN....................22

3.3.4.1 Introdução........................................................................................................ 22

3.3.4.2 A TRMN na Medicina Veterinária...................................................... 23

3.3.4.3 Formação de Imagens.............................................................................24

3.3.4.3.1 Gradientes............................................................................25

3.3.4.4 Aspectos Tomográficos de Amostras............................................. 26

3.3.4.5 Instrumentação............................................................................. 28 


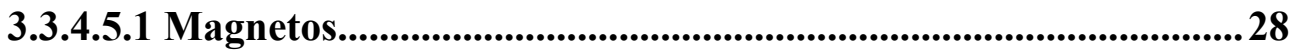

3.3.4.5.2 Gradientes..............................................................................................29

3.3.4.5.3 Bobinas de RF.................................................................................... 29

3.4 Contenção de Aves Silvestres............................................................................30

3.4.1 Contenção Física.............................................................................................30

3.4.2 Contenção Farmacológica....................................................................................31

3.4.2.1 Aspectos Gerais.............................................................................................31

3.4.2.2 Cloridrato de Quetamina............................................................................33

3.4.2.3 Cloridrato de Xilazina............................................................................33

3.4.2.4 Associação Anestésica de Quetamina e Xilazina.................................. 34

3.4.2.4.1 Doses da Associação Anestésica de Quetamina

e Xilazina Recomendadas para Aves................................................35

3.4.2.4.2 Cuidados Necessários Durante o Período

de Recuperação Anestésica em Aves..............................................37

3.5 Aratinga leucophthalmus..............................................................................................38

4 Materiais e Método...............................................................................................................40

4.1. Pré-Experimento....................................................................................................... 40

4.1.1 Tomógrafo...........................................................................................................40

4.1.2 Animais.....................................................................................................40

4.1.3 Critérios Estabelecidos.................................................................................41

4.1.3.1 Imagens Tomográficas............................................................................ 41

4.1.3.2 Identificação dos Lados Esquerdo e Direito da Imagem.................... 42

4.1.3.3 Ajustes do Equipamento x Qualidade de Imagem.............................. 42

4.1.3.4 Determinação do Posicionamento da Ave Dentro do Tomógrafo...42

4.1.3.5 Escolha dos Anestésicos........................................................................... 43

4.1.3.6 Determinação da Dose Anestésica............................................................43

4.1.3.7 Escolha da Espécie de Ave........................................................................ 44

4.1.3.8 Desenvolvimento de Protocolo de Exame.............................................. 44

4.2 Experimento Definitivo................................................................................45

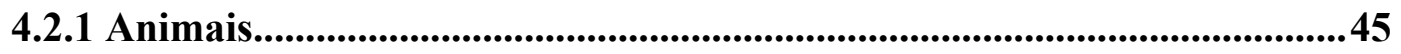




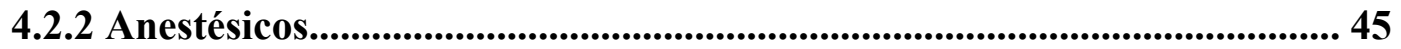

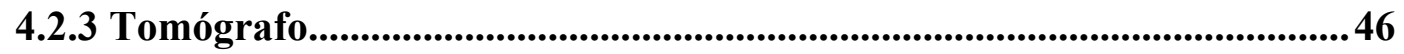

4.2.4 Protocolo de Exame...........................................................................47

4.2.4.1 Preparação da Ave para o Exame Tomográfico................................47

4.2.4.1.1 Transporte......................................................................... 47

4.2.4.1.2 Contenção Física.......................................................................... 47

4.2.4.1.3 Pesagem........................................................................................................48

4.2.4.1.4 Procedimento Anestésico..........................................................49

4.2.4.2 Exame Tomográfico......................................................................49

4.2.4.2.1 Posicionamento da Ave...............................................................49

4.2.4.2.2 Ajustes do Equipamento...........................................................52

4.2.4.2.3 Aquisição das Imagens............................................................. 53

4.2.4.3 Procedimento Pós-Exame Tomográfico................................................ 55

4.2.4.3.1 Colocação das Anilhas...............................................................55

4.2.4.3.2 Recuperação Anestésica.................................................................... 56

4.2.5 Exame de Polimorfismo de DNA.........................................................57

4.2.6 Análise Estatística..........................................................................57

5 RESULTADOS....................................................................................................... 58

5.1 Avaliação dos Anestésicos Utilizados.............................................................. 58

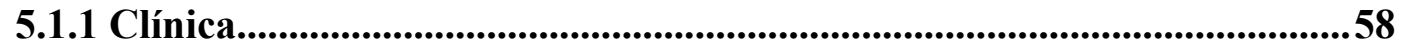

5.1.2 Dose Anestésica Utilizada..................................................................... 58

5.1.3 Período de Latência e Período Hábil Anestésico.....................................59

5.2 Avaliação do Exame Tomográfico....................................................................60

5.2.1 Tempo de Duração do Exame Tomográfico............................................... 60

5.2.2 Interpretação das Imagens Tomográficas...............................................61

5.3 Exame de Polimorfismo de DNA................................................................. 64

6 Discussão...........................................................................................................................65

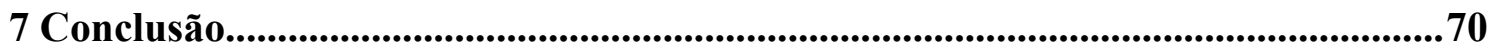

8 Referências Bibliográficas........................................................................... 71 
Anexo 1 Comissão de Ética em Experimentação Animal (CEEA) do Instituto de Ciências Biomédicas da Universidade de São Paulo (ICB/USP)............................................................................... 82

Anexo 2 Licença IBAMA Processo número 02027. 008093/01-93.................................83

Anexo 3 Sexagem de Aves pelo Exame de Polimorfismo de DNA.................................84

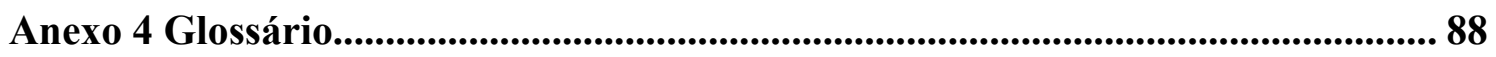


Lista de Figuras

Figura 1 - a) Testículo esquerdo maduro em época reprodutiva (seta); b) Testículos imaturos (seta)......................................................................... 8

Figura 2 -Sistema urogenital masculino de periquito australiano...................... 9

Figura 3-Sistema reprodutor masculino de pardal (Passer domesticus) em época reprodutiva (a) e fora da época reprodutiva (b).......................... 10

Figura 4 - Sistema urogenital feminino de periquito australiano imaturo...... 11

Figura 5 - a) Ovário imaturo (seta); b) Ovário maduro em época reprodutiva, com folículos bem desenvolvidos, dando ao ovário a aparência de cacho de uvas (seta)

Figura 6 -Ovário e oviduto de periquito australiano maduro em época reprodutiva. No útero, observa-se a presença de um ovo..................... 13

Figura 7 - Representação do átomo............................................................... 15

Figura 8 - Movimento de precessão do momento angular em torno do campo estático $B_{0}$

Figura 9- Magnetização (M) gerada pela soma dos momentos magnéticos dos núcleos presentes na amostra.....................................................................

Figura 10 - Demonstração dos pulsos de $\pi / 2$ e $\pi$, que provocam, respectivamente, rotação de 90 e de 180 graus na magnetização M.......

Figura 11 - Imagens axiais de crânio, sendo: A - ponderada por T1, B ponderada por densidade de próton, $\mathrm{C}$ - ponderada por $\mathrm{T} 2$.....................

Figura 12 - Demonstração das diferentes formas de contenção física para os psitacídeos...........................................................................................

Figura 13 - Periquitão-maracanã (Aratinga leucophthalmus).

Figura 14 - a) Seqüência parcial de imagens tomográficas de Arara Canindé (Ara ararauna) (plano coronal). Campo de visão: $11 \mathrm{~cm} \times 24 \mathrm{~cm}$; b) Seqüência total de imagens tomográficas de Papagaio verdadeiro 
(Amazona aestiva) (plano coronal). Campo de visão: $13 \mathrm{~cm} x$ $24 \mathrm{~cm}$

Figura 15 - Anestésicos utilizados no experimento.

Figura 16 - Tomógrafo de ressonância magnética nuclear da Embrapa Instrumentação Agropecuária.

Figura 17 - Contenção física do periquitão-maracanã (Aratinga leucophthalmus) 48

Figura 18 - Caixa e balança utilizadas para a pesagem dos animais. 48

Figura 19 - Tubos contendo óleo em seu interior. 50

Figura 20 - Tubo contendo óleo colocado sob a asa esquerda do periquitãomaracanã (Aratinga leucophthalmus) (seta branca).

Figura 21 - Periquitão-maracanã (Aratinga leucophthalmus) dentro da bandeja e envolto pelo filme plástico.

Figura 22 - Posicionamento do periquitão-maracanã (Aratinga leucophthalmus) dentro do tomógrafo.

Figura 23 - Sintonização da bobina de detecção.

Figura 24 - a) Representação esquemática da secção do corpo de um psitacídeo no plano sagital; b) Representação esquemática da secção do corpo de um psitacídeo no plano coronal.

Figura 25 - a) Imagem tomográfica do periquitão-maracanã (Aratinga leucophthalmus) no plano sagital, em que o rim corresponde à seta vermelha; b) c) d) Imagens tomográficas no plano sagital, demonstrando as três diferentes inclinações das linhas de cortes tomográficos utilizadas para a aquisição das imagens coronais. Campo de visão: $7 \mathrm{~cm} \times 14 \mathrm{~cm}$.

Figura 26 - Seqüência de imagens tomográficas do periquitão-maracanã (Aratinga leucophthalmus) no plano coronal. Campo de visão: $7 \mathrm{~cm} x$ $14 \mathrm{~cm}$.

Figura 27 - Anilhas utilizadas para identificação das aves............................... 56

Figura 28 - Colocação da anilha. 
Figura 29 - Periquitão-maracanã (Aratinga leucophthalmus) sendo envolto pelo jornal..........................................................................................................

Figura 30 - Rins (seta branca) e testículos (seta azul) de Arara Canindé (Ara ararauna), fixados em formol a $10 \%$. Em destaque, os testículos

Figura 31 - a) Rins (seta branca) e testículos (seta azul) de Arara Canindé (Ara ararauna), fixados em formol a 10\%; b) Imagem tomográfica dos rins (seta branca) e testículos (seta azul) de Arara Canindé, fixados em formol a $10 \%$ Campo de visão: $6 \mathrm{~cm} \quad \mathrm{x}$ $8 \mathrm{~cm}$.

Figura 32 - a) Rins (seta branca) e testículos (seta azul) de papagaio cinza africano (Psittacus erithacus) macho, em época reprodutiva; b) Imagem tomográfica dos rins (seta branca) e testículos (seta azul) de um periquitão-maracanã (Aratinga leucophthalmus) macho, em época reprodutiva. Campo de visão: $7 \mathrm{~cm} \times 14 \mathrm{~cm}$.

Figura 33 - a) Imagem tomográfica do animal número 7 - periquitãomaracanã (Aratinga leucophthalmus) macho; b) Imagem tomográfica do animal número 9 - periquitão-maracanã (Aratinga leucophthalmus) fêmea. $O$ círculo destaca a região anatômica em que os testículos (no macho) e as glândulas adrenais (em ambos) estão localizados. A seta azul indica o tubo contendo óleo, que determina o lado esquerdo da imagem. Campo de visão: $7 \mathrm{~cm} \times 14 \mathrm{~cm}$

Figura 34 - a) Rins (seta branca) e ovário esquerdo (seta azul) de fêmea madura sexualmente, de papagaio cinza africano (Psittacus erithacus); b) Imagem tomográfica dos rins (seta branca) e glândulas adrenais (seta vermelha) de um periquitão-maracanã (Aratinga leucophthalmus) fêmea. Campo de visão: $7 \mathrm{~cm} \times 14 \mathrm{~cm}$.............................

Figura 35 - Kit para a coleta de sangue composto de lanceta e papel filtro...... 84

Figura 36 - Demonstração dos genes em forma de bandas no gel....................... 87 
Lista de Tabelas

Tabela 1 - Número de indivíduos não sexados de 12 espécies da família Psittacidae existentes nos zoológicos brasileiros...................................... 3

Tabela 2 - Características da associação quetamina/xilazina (10-30mg/kg quetamina)............................................................................................................. 35

Tabela 3 - Doses da associação anestésica de quetamina e xilazina para aves, recomendadas por diferentes autores........................................................ 36

Tabela 4 - Animais utilizados no pré-experimento.......................................... 41

Tabela 5 - Dose anestésica utilizada no experimento definitivo......................... 59

Tabela 6 - Período de latência e período hábil anestésico.................................. 59

Tabela 7 -Tempo de duração do exame tomográfico.......................................... 60

Tabela 8 - Tempo de duração do exame tomográfico se fossem realizadas três aquisições de imagens coronais para cada animal.............................. 61

Tabela 9 - Resultado do exame de polimorfismo de DNA............................... 64

Tabela 10 - Comparação da TRMN com os principais métodos utilizados para sexagem de aves...................................................................... 68 


\section{Lista de Símbolos e Siglas}

$$
\begin{array}{ll}
\gamma & =\text { constante de razão giromagnética } \\
\omega & =\text { freqüência angular } \\
\pi & =\text { pi } \\
{ }^{\circ} \text { C } & =\text { graus centígrados ou Celsius } \\
\text { 3D } & =\text { tridimensional } \\
\text { B1 } & =\text { campo magnético oscilante } \\
\text { Bo } & =\text { campo magnético externo } \\
\text { C } & =\text { carbono } \\
\text { cc } & =\text { centímetro cúbico } \\
\text { CEEA } & =\text { Comissão de Ética em Experimentação Animal } \\
\text { CETAS } & =\text { Centro de Triagem de Animais Silvestres } \\
\text { CHD } & =\text { chromo-helicase-DNA-binding } \\
\text { cm } & =\text { centímetro } \\
\text { COBEA } & =\text { Colégio Brasileiro de Experimentação Animal } \\
\text { F } & =\text { flúor } \\
\text { FID } & =\text { Free Induction Decay } \\
\text { g } & =\text { grama } \\
\text { H } & =\text { hidrogênio }
\end{array}
$$

IBAMA = Instituto Brasileiro de Meio Ambiente e dos Recursos Naturais Renováveis

ICB $=$ Instituto de Ciências Biomédicas

K $=$ Kelvin

kg = quilograma

$\mathbf{l}_{\mathbf{p e}} \quad=$ length phase - encode axis

$\mathbf{I}_{\mathbf{r o}} \quad=$ length readout axis

M $=$ magnetização 


$$
\begin{array}{ll}
\mathbf{m g} & =\text { miligrama } \\
\mathbf{M H z} & =\text { megahertz } \\
\mathbf{m i n} & =\text { minutos } \\
\mathbf{m l} & =\text { mililitro } \\
\mathbf{m m} & =\text { milímetro } \\
\mathbf{N a} & =\text { sódio } \\
\mathbf{P} & =\text { fósforo } \\
\mathbf{P C R} & =\text { polymerase chain reaction } \\
\mathbf{P V C} & =\text { polivinil cloreto } \\
\mathbf{R F} & =\text { radiofrequiência } \\
\mathbf{R M N} & =\text { ressonância magnética nuclear } \\
\mathbf{S} & =\text { segundo } \\
\mathbf{S N C} & =\text { sistema nervoso central } \\
\mathbf{S Z B} & =\text { Sociedade de Zoológicos do Brasil } \\
\mathbf{T} & =\text { Tesla } \\
\mathbf{T} & =\text { tempo de relaxação longitudinal } \\
\mathbf{T} & =\text { tempo de relaxação transversal } \\
\mathbf{T E} & =\text { tempo ao eco } \\
\mathbf{T R} & =\text { tempo de repetição } \\
\mathbf{T R M N} & =\text { tomografia por ressonância magnética nuclear } \\
\mathbf{X X} & =\text { cromossomos sexuais de mamíferos fêmeas } \\
\mathbf{X Y} & =\text { cromossomos sexuais de mamíferos machos } \\
\mathbf{Z W} & =\text { cromossomos sexuais de aves fêmeas } \\
\mathbf{Z Z} & =\text { cromossomos sexuais de aves machos }
\end{array}
$$




\section{Resumo}

GRANDO, A. P. (2002). Utilização de tomografia por ressonância magnética nuclear para sexagem de aves silvestres sem dimorfismo sexual. São Carlos. 85p. Dissertação (Mestrado) - Escola de Engenharia de São Carlos/Faculdade de Medicina de Ribeirão Preto/Instituto de Química de São Carlos, Universidade de São Paulo.

O rápido declínio da vida silvícola do planeta tem levado inúmeros pesquisadores a discutirem diferentes estratégias de conservação, tanto com a manutenção dos animais em seus próprios habitats naturais, como pela propagação em cativeiro. A reprodução de aves em cativeiro é dificultada quando esses animais não apresentam dimorfismo sexual (ausente em muitas espécies, especialmente em psitacídeos), requerendo a realização de métodos de sexagem para a formação de casais. Dessa forma, foi estudado o uso da tomografia por ressonância magnética nuclear (TRMN) para a sexagem de aves silvestres sem dimorfismo sexual, por meio da visualização de seus órgãos reprodutivos. Dez animais da espécie Aratinga leucophthalmus foram anestesiados e submetidos a exames tomográficos. Nas imagens tomográficas adquiridas, pôde-se visualizar os testículos determinando o sexo masculino em aves sexualmente maduras. Entretanto, nas fêmeas, o formato anatômico do ovário esquerdo (provavelmente imaturo) não permitiu que ele fosse caracterizado com precisão por esse método. Para a confirmação dos resultados dos exames tomográficos, foram realizadas análises de polimorfismo de DNA.

Palavras-chave: ressonância magnética; sexagem; aves silvestres. 


\section{Abstract}

GRANDO, A. P. (2002). Utilization of nuclear magnetic resonance tomography for sex identification in wild birds without sexual dimorphism. São Carlos. 85p. Dissertação (Mestrado) - Escola de Engenharia de São Carlos/Faculdade de Medicina de Ribeirão Preto/Instituto de Química de São Carlos, Universidade de São Paulo.

The fast decline of wild life on the planet has led innumerable researchers to discuss different conservation strategies by both maintaining animals in their own natural habitat and reproducing in captivity. Reproduction in captivity becomes difficult when these animals do not present sexual dimorphism (absent in many species, specially in psittacines), requiring the use of methods for sex identification to form couples. Thus the use of magnetic resonance imaging (MRI) to identify the sex of birds without sexual dimorphism through the visualization of their reproductive organs has been studied. Ten animals of the Aratinga leucophthalmus species were anaesthetized and subject to tomographic exams. In the tomographic images obtained it was possible to visualize the testicles identifying the male sex in sexually mature birds. However, in the females, the left ovary (possible immaturity) could not be precisely characterized by this method, due to its anatomical shape. To confirm the results of the tomographic exams, analyses of DNA polimorphism were performed.

Keywords: magnetic resonance; sex identification; wild birds. 


\section{Introdução}

Segundo LEAL ${ }^{[1]}$, no Brasil, país que ocupa o primeiro lugar no ranking da megadiversidade ${ }^{1}$, mais de duas centenas de espécies da fauna e quase uma centena da flora estão ameaçadas de extinção. As principais causas são a explosão demográfica, o desenvolvimento não-sustentável, o desmatamento, a contaminação das águas, o lixo industrial, a destruição dos habitats naturais, a caça desenfreada, o comércio local e internacional de espécies e produtos/subprodutos da fauna e da flora silvestre brasileira. Assim sendo, a intervenção humana, certamente, tem sido a maior responsável pela situação de fragilidade e desaparecimento de diversas plantas e animais.

Entre os dezessete países que concentram $70 \%$ da biodiversidade da Terra, o Brasil tem a maior parte. Essa riqueza natural pode ser medida, por exemplo, pelo número de aves (1677 espécies) ${ }^{[2]}$. A fauna brasileira é a mais rica em psitacídeos (os papagaios, araras, periquitos e jandaias), contando com 72 espécies ${ }^{[2,3]}$. Como é de se esperar, essa riqueza silvestre atrai a atenção dos especuladores, contribuindo dessa forma para que o Brasil se ordene como segundo país vítima de extinção ornitófila, perdendo apenas para a Indonésia $[2,4]$.

Por meio da Portaria $n^{0} 1522$, de 19 de dezembro de 1989, o Instituto Brasileiro de Meio Ambiente e dos Recursos Naturais Renováveis (IBAMA), instituiu a lista oficial de espécies da fauna brasileira ameaçadas de extinção. Nela estão contidas 208 espécies; entretanto, anualmente o IBAMA edita novas portarias incluindo outras espécies da fauna nessa lista, o que significa que o número de animais em extinção tem aumentado anualmente ${ }^{[1]}$. Dessa forma, sob a coordenação da Fundação Biodiversitas de Belo Horizonte, e com a

\footnotetext{
${ }^{1}$ A megadiversidade envolve a diversidade biológica (espécies da fauna e da flora) e a diversidade de ecossistemas (habitats dessas espécies) ${ }^{[1]}$.
} 
colaboração do IBAMA, está sendo preparada uma lista atualizada de animais com risco de extinção no país. Biólogos da entidade afirmam que a lista atual inclui sete espécies provavelmente já extintas, e que mais de 170 podem ser incluídas na proteção ${ }^{[2]}$.

Esse rápido declínio da vida silvícola do planeta tem levado inúmeros pesquisadores a discutirem diferentes estratégias de conservação, tanto com a manutenção dos animais em seus próprios habitats naturais, como pela propagação em cativeiro ${ }^{[5]}$. Além disso, a Legislação Ambiental Brasileira, pela Portaria $\mathrm{n}^{\circ}$ 005/91-N, de 25 de abril de 1991, obriga o acasalamento de animais da fauna nativa mantidos em cativeiro, solteiros, constantes da Lista Oficial de Espécies Ameaçadas de Extinção. Obriga, também, que a manutenção de espécies que estejam em estado crítico de extinção tenha como finalidade primordial sua reprodução, ficando a exposição ao público (em caso de zoológicos) limitada àquelas espécies cujo sucesso reprodutivo em cativeiro for comprovado ${ }^{[6]}$.

Dessa forma, o interesse em programas de reprodução em cativeiro tem se tornado mais forte nos recentes anos, e o alicerce desses programas se constitui na correta sexagem de pares ${ }^{[7]}$. Assim sendo, no que diz respeito às aves brasileiras, a família Psittacidae é a que apresenta o maior número de espécies ameaçadas (treze das setenta e duas conhecidas se encontram na lista oficial da fauna brasileira ameaçada de extinção), e isso faz com que haja grande interesse por parte dos zoológicos e criadores conservacionistas em reproduzir esses animais em cativeiro. Porém, o problema deparado na tentativa da reprodução de psitacídeos fora do ambiente natural é a formação dos casais, visto que, à exceção de poucas espécies, estas não apresentam dimorfismo sexual $^{2}$, fazendo-se necessário o uso de técnicas de sexagem para sua identificação ${ }^{[5]}$.

Analisando-se os dados do censo 2000 da Sociedade de Zoológicos do Brasil (SZB), pode-se ter uma idéia da dimensão do problema que a ausência de dimorfismo sexual significa para a propagação dos psitacídeos em cativeiro.

\footnotetext{
${ }^{2}$ Dimorfismo sexual: fenômeno comum em insetos e aves em que, na mesma espécie, a fêmea difere do macho em tamanho, cor etc. ${ }^{[9]}$.
} 
Esses dados revelam que aproximadamente $65 \%$ das aves da família Psittacidae existentes nos zoológicos de todo o Brasil não foram sexadas. Dessa forma, pode-se observar a importância das pesquisas para o desenvolvimento e aperfeiçoamento de técnicas que permitam a identificação do sexo de espécies de aves que não apresentam dimorfismo sexual.

Na Tabela 1 está relacionado o número de indivíduos não sexados de 12 das 79 espécies da família Psittacidae existentes nos zoológicos brasileiros ${ }^{[8]}$.

Tabela 1 - Número de indivíduos não sexados de 12 espécies da família Psittacidae(*) existentes nos zoológicos brasileiros ${ }^{[8]}$.

\begin{tabular}{ccccc}
\hline Espécie & Espécie & Aves não sexadas & No total \\
\cline { 3 - 4 } Nome científico & Nome comum & $\mathbf{n}^{\mathbf{0}}$ & $\mathbf{\%}$ & de aves \\
\hline Amazona aestiva & Papagaio verdadeiro & 484 & 87 & 558 \\
Amazona rhodocorytha & Papagaio chua & 17 & 45 & 38 \\
Anodorhynchus hyacinthinus & Arara Una & 24 & 28 & 87 \\
Ara ararauna & Arara Canindé & 420 & 75 & 559 \\
Ara nobilis & Ararinha & 86 & 69 & 124 \\
Aratinga aurea & Jandaia coquinho & 99 & 74 & 133 \\
Aratinga guarouba & Ararajuba & 44 & 38 & 116 \\
Aratinga leucophthalmus & Jandaia maracanã & 254 & 77 & 328 \\
Aratinga s. solstitialis & Jandaia sol & 39 & 72 & 54 \\
Brotogeris chiriri & Periquito de asa amarela & 71 & 100 & 71 \\
Brotogeris tirica & Periquito verde & 67 & 88 & 76 \\
Pionus maximilliani & Curica & 84 & 85 & 99 \\
\hline
\end{tabular}

(*) Existem 79 espécies da família Psittacidae distribuídas pelos zoológicos brasileiros. Acima estão relacionadas apenas 12 dessas espécies, como forma ilustrativa. 


\section{Objetivo}

A presente pesquisa busca avaliar a eficiência do uso da tomografia por ressonância magnética nuclear na sexagem de aves silvestres que não apresentam dimorfismo sexual, pela visualização de seus órgãos sexuais. 


\section{Revisão da Literatura}

\subsection{Sexagem de Aves Monomórficas}

As aves monomórficas, ou seja, aves que não apresentam dimorfismo sexual entre o macho e a fêmea, podem apresentar essa característica de "monomorfismo", temporariamente, antes de atingirem a maturidade sexual, como é o caso dos curiós, por exemplo, ou podem carregar essa característica por toda a sua vida, como no caso dos papagaios ${ }^{[10]}$. Devido a essa característica, durante muitos anos criadores formavam os casais de aves ao acaso ou baseados nas características comportamentais, mas, entretanto, pares de mesmo sexo alojados juntos podem ser altamente compatíveis, e no caso de fêmeas, podem até mesmo realizar a postura de ovos inférteis. Até hoje, essa é uma causa comum da falta de sucesso reprodutivo dos psitacídeos, uma vez que cerca de $80 \%$ dessas aves são monomórficas ${ }^{[11,12]}$. Sendo assim, com o tempo se fez necessário a criação de diferentes técnicas para a determinação do sexo dessas aves, a saber:

- Laparoscopia - A laparoscopia é uma análise morfológica na qual é possível visualizarem as gônadas ${ }^{3}$ dos animais por meio de uma pequena intervenção cirúrgica ${ }^{[13]}$. Com essa técnica, também se pode observar qualquer anormalidade nas gônadas ou órgãos vizinhos. A laparoscopia é extremamente exata, e o cirurgião tem um claro campo de visão. Porém, existem desvantagens, tais como o risco cirúrgico, a possibilidade de infecções decorrentes de uma deficiente técnica cirúrgica e a dificuldade de contenção pós-operatória ${ }^{[11,13]}$. Além disso, ela somente é eficiente em aves que já atingiram a maturidade sexual ${ }^{[13]}$.

- Análise citogenética - A análise citogenética, ou seja, a determinação das características cromossômicas das várias espécies de aves, vem contribuindo sobremaneira para o estabelecimento das relações taxômicas e evolutivas entre os

\footnotetext{
${ }^{3}$ Gônada: glândula sexual que produz os gametas e segrega os hormônios. O testículo é a gônada masculina e o ovário, a
} feminina ${ }^{[16]}$. 
vários grupos. Essa técnica tem trazido outras contribuições, inclusive possibilitando a identificação do sexo em espécies que não apresentam dimorfismo sexual fenotípico aparente, no qual a presença do cromossomo $\mathrm{W}$, restrito às fêmeas, possibilita essa identificação sexual pelo cariótipo ${ }^{[13,14]}$. No estudo do cariótipo, os cromossomos são contados, medidos e morfologicamente analisados. Para a obtenção dos cromossomos metafásicos (próprios para a análise citogenética) existem inúmeras técnicas, dentre elas a cultura de linfócitos do sangue periférico, cultura de polpa de penas, métodos diretos, utilizando células de medula óssea ou de embriões. Embora a retirada de penas (6-8 maduras e após 10-20 dias, as jovens crescidas no local) seja um processo doloroso para o animal, o uso de métodos que utilizam material extraído de sua polpa é muito útil ao possibilitar o estudo citogenético de aves raras ou de zoológicos, sem a necessidade de sacrificá-las, como é o caso quando se utilizam células de embriões ou de medula óssea, sendo esta última a técnica mais rápida, prática e que resulta geralmente em lâminas com grandes quantidades de metáfases ${ }^{[14,15]}$. A maior desvantagem dessa técnica que utiliza polpa de penas em crescimento é que as amostras devem ser enviadas ao laboratório de um dia para o outro (36-40 horas), e certamente por isso, uma porcentagem do material não sobrevive ${ }^{[11,12,17]}$. Outro fator limitante é a dificuldade de obtenção de número adequado de penas em crescimento, uma vez que o fator mais importante para os estudos citogenéticos é a existência de metáfases de boa qualidade e quantidade para permitir os diversos tipos de análises ${ }^{[7,15]}$. Constitui-se ainda em um método extremamente trabalhoso, podendo levar até 20 dias para a obtenção do resultado ${ }^{[13,17]}$.

- Análise de DNA - No caso da identificação do DNA do cromossomo W (fêmea-específico), seu estudo pode ser realizado de forma quantitativa ou qualitativa. A primeira pode ser realizada utilizando-se um citômetro de fluxo para quantificar o DNA da célula. Essa é uma técnica dispendiosa, porque requer um citômetro de fluxo e apresenta uma certa margem de erros, não sendo capaz de identificar os sexos em todos os casos. A análise qualitativa pode ser feita pela técnica de hibridação, utilizando sondas de minissatélite humano. No entanto, tem sua aplicabilidade limitada, por necessitar de maior quantidade de sangue e de DNA, e de um intervalo de tempo mais longo para a obtenção dos resultados ${ }^{[13]}$. Outra 
técnica qualitativa mais recente utiliza a reação de amplificação de PCR (Polimerase Chain Reaction), que requer apenas pequena amostra de sangue. Esta técnica, embora rápida, não demonstra eficiência em aves ratitas, e também existe a dificuldade de coleta de sangue em animais silvestres. Além disso, há o risco de contaminação do material durante a coleta, levando a resultados inconclusivos ${ }^{[13]}$.

- Análise fecal - A análise fecal se constitui na análise de hormônios sexuais nas fezes, em que a quantidade de estrógeno é comparada à de testosterona, sendo o sexo determinado pela razão dos dois. É uma técnica não-invasiva, que permite a coleta de amostras por intervalos longos de tempo, sem a manipulação e o conseqüente estresse do animal, mas possui aplicabilidade limitada ao período reprodutivo do mesmo ${ }^{[11,18,19,20]}$. Inicialmente havia alta esperança para essa técnica, mas os resultados não são confiáveis em aves imaturas ou maduras, mas sexualmente inativas. Uma outra técnica tem também sido desenvolvida para analisar esses hormônios em amostras de sangue, mas esse procedimento também não tem se mostrado confiável ${ }^{[11]}$.

- Ultra-sonografia - Em estudos recentes, encontra-se o uso da ultrasonografia transcloacal em aves de rapina e pingüins adultos para a visualização do oviduto esquerdo desses animais, mas esse é um método que ainda necessita de estudos adicionais para o estabelecimento de sua precisão ${ }^{[21,22]}$.

Existem vários métodos de sexagem, cada qual com suas vantagens e limitações; em alguns casos, a identificação sexual não é efetiva utilizando-se uma determinada técnica, tendo-se que repetir várias vezes a análise ou recorrer a outro tipo de exame até o êxito total.

Cada instituição conservacionista deve conhecer as diferentes formas de sexagem e optar por aquela que melhor atende às exigências/necessidades de seus animais. 


\subsection{Revisão Anatômica}

Será realizada a descrição das características dos órgãos reprodutivos das aves, alvo de estudo nesse trabalho, e também, devido a sua localização muito próxima aos rins e glândulas adrenais, as características destes órgãos também serão descritas.

\subsubsection{Sistema Reprodutor Masculino}

O sistema reprodutor masculino consiste de um par de testículos, de epidídimos e de ductos deferentes. Glândulas acessórias estão ausentes, e algumas espécies possuem um órgão copulador rudimentar, que é capaz de ereção linfática ${ }^{[23,24]}$. O macho tem sempre dois testículos, sendo o esquerdo geralmente maior que o direito; eles são intra-abdominais, e nunca descem para a região externa ao corpo ${ }^{[23,24,25,26,27]}$. Segundo EVANS ${ }^{[23,24]}$, os testículos são ovais ou redondos, enquanto que para MCDONALD ${ }^{[11]}$, eles são oblongos (quando maduros e em atividade sexual) ou cilíndricos (quando imaturos) (Figuras 1a e 1b), com a superfície lisa, e de coloração branco-creme, podendo ser melanísticos (preto esverdeado) em algumas espécies. Em psitacídeos, todo macho de cacatua alba (gênero Cacatua), cacatua de Galah (Eolophus roseicapillus) e muitas das espécies de periquito australiano (gêneros Alisterus, Polytelis e Platycercus) têm testículos melanísticos.

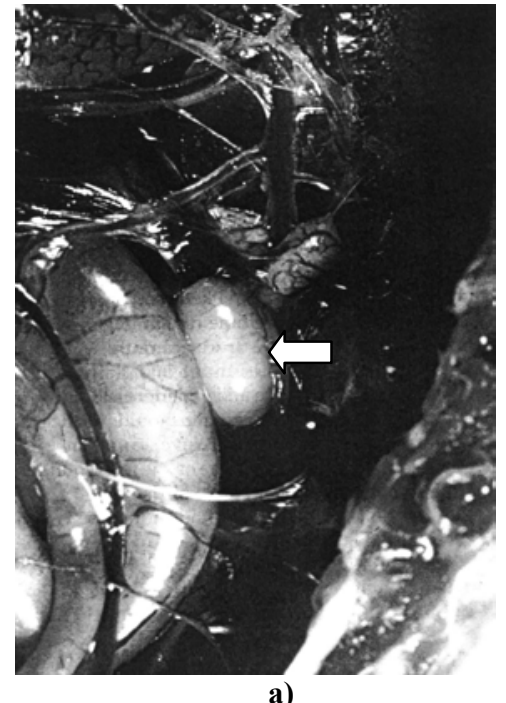

a)

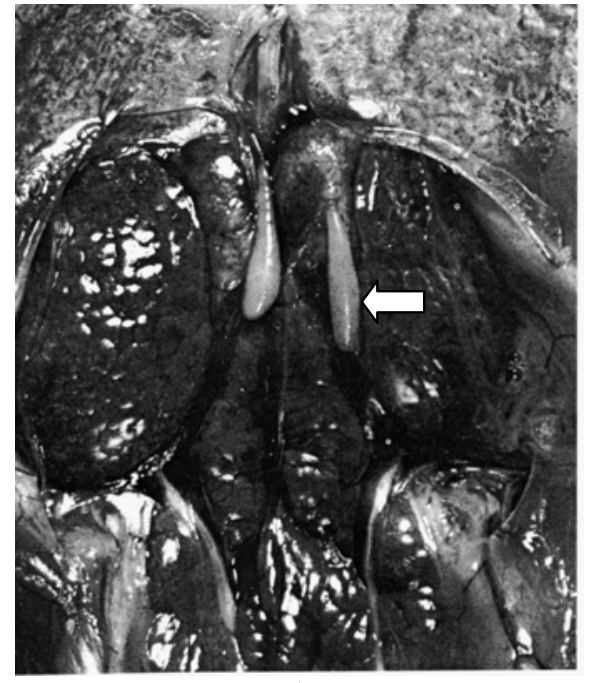

b)

Figura 1 - a) Testículo esquerdo maduro em época reprodutiva (seta); b) Testículos imaturos (seta) ${ }^{[11]}$. 
Os testículos esquerdo e direito estão dispostos simetricamente em cada lado da linha média, no teto do celoma. Cada testículo está situado cranioventralmente à divisão cranial do rim. Caudalmente, aproximam-se da veia ilíaca comum. Cranialmente, relacionam-se com a superfície ventral do pulmão. Medialmente, localizam-se próximo da aorta, veia cava caudal e das glândulas adrenais (Figura 2). Encontra-se circundado pelos sacos aéreos abdominais, especialmente em sua extremidade cranial. O testículo ativo não é firme ao toque, como nos mamíferos, e possui muito fluido leitoso composto de lipoproteínas e espermatozóides. Um curto mesentério o suspende no teto do celoma, entre a aorta e o rim. Esse mesentério está inserido na superfície ventral do testículo, e portanto, oculta o epidídimo de uma observação ventral ${ }^{[28]}$.

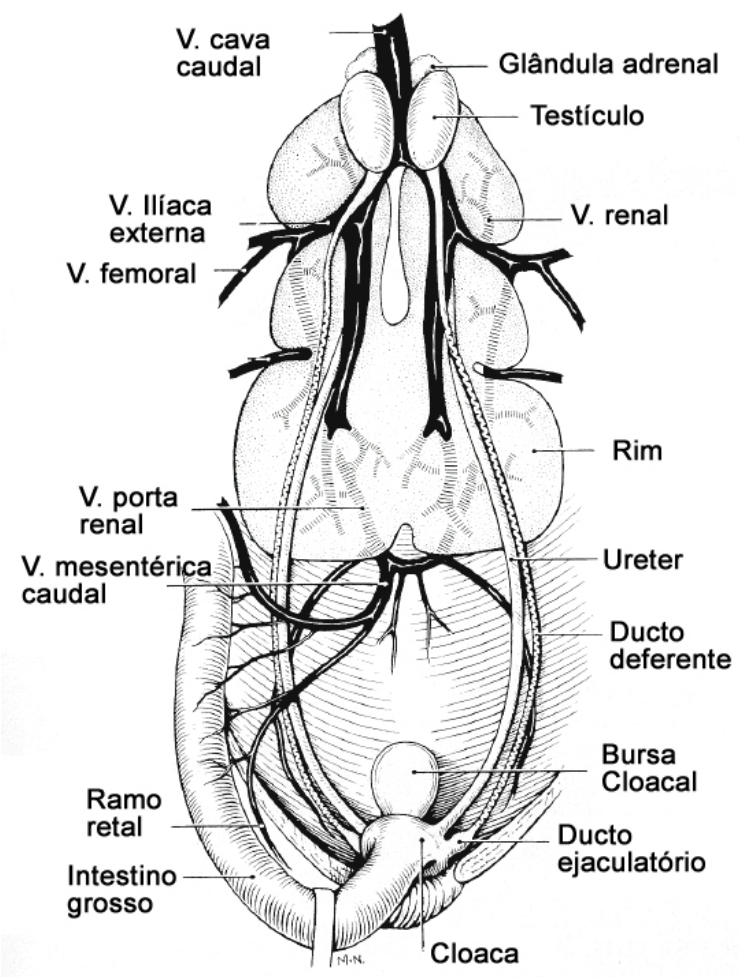

Figura 2 - Sistema urogenital masculino de periquito australiano ${ }^{[24]}$.

Os testículos podem variar em tamanho, dependendo da maturidade sexual da ave e do estágio do ciclo reprodutivo em que ela se encontra. Dessa forma, em aves imaturas sexualmente, os testículos são muito pequenos, e normalmente avascularizados, enquanto que em aves maduras, podem variar em tamanho, 
aumentando muito durante a época de procriação, e atrofiando após esse período (Figura 3) ${ }^{[11,27,29]}$. Durante a época de estímulo sexual, em geral, eles se tornam maiores do que a glândula adrenal adjacente e mais vascularizados na superfície. Em pombas e aves domésticas, o tamanho do testículo é freqüentemente muito maior do que o pólo cranial do rim. Já no caso dos psitacídeos, o tamanho máximo desse órgão durante a estimulação sexual não é tão grande como em muitas outras espécies ${ }^{[11]}$.

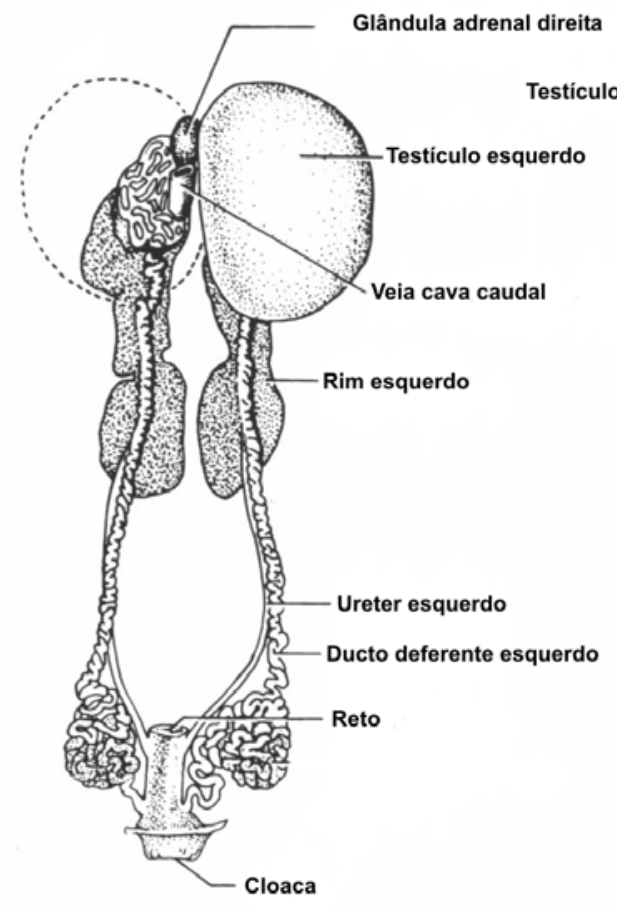

a)

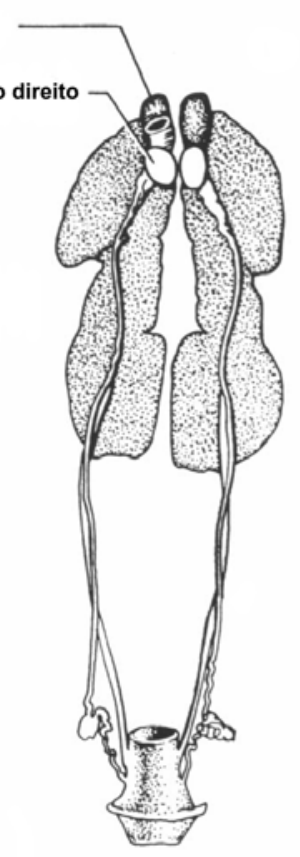

b)

Figura 3 - Sistema reprodutor masculino de pardal (Passer domesticus) em época reprodutiva (a) e fora da época reprodutiva (b) ${ }^{[25]}$.

Os túbulos seminíferos, localizados no interior dos testículos, transportam os espermatozóides até o epidídimo. O epidídimo é uma estrutura alongada e fusiforme, intimamente inserida ao longo de todo o comprimento da borda dorsomedial do testículo ${ }^{[28]}$. Segundo EVANS ${ }^{[23,24]}$, não é possível visualizá-lo sem dissecação. O ducto deferente, por sua vez, origina-se do epidídimo no pólo caudodorsal do testículo, diverge lateralmente e prossegue paralelo ao ureter no restante do seu curso. Juntamente com o ureter, penetra na parede da cloaca, na região dorsal do urodeo ${ }^{4}$, conforme a Figura $2^{[23,24,28]}$.

${ }^{4}$ Urodeo: juntamente com o coprodeo e o proctodeo, constituem os compartimentos da cloaca das aves ${ }^{[28]}$. 


\subsubsection{Sistema Reprodutor Feminino}

O sistema reprodutor feminino das aves consiste de um ovário esquerdo localizado no pólo cranial do rim esquerdo, unido por um curto mesovário à parede dorsal do corpo, e um oviduto esquerdo, suportado pelo mesotubário (Figura 4) $[12,23,24]$.

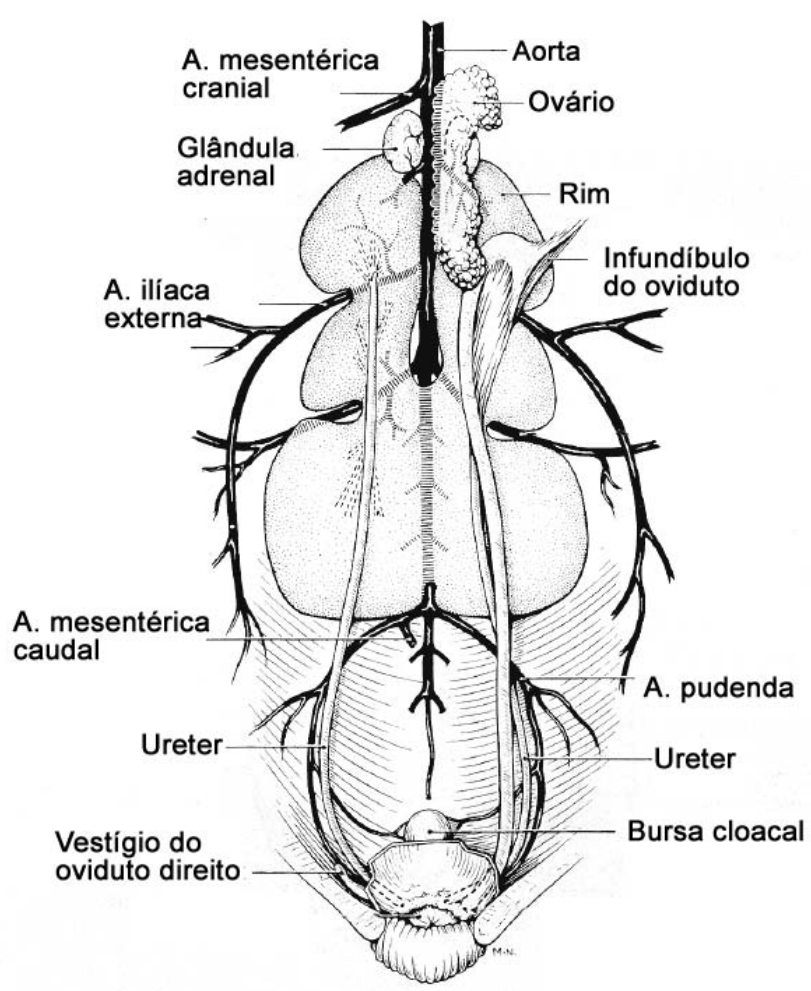

Figura 4 - Sistema urogenital feminino de periquito australiano imaturo ${ }^{[24]}$.

O processo de reprodução é por fecundação interna; são ovíparas, isto é, põem ovos que eclodem fora do organismo materno ${ }^{[30]}$.

Embora os ovários e ovidutos da ave se desenvolvam como estruturas pares, eles logo se tornam assimétricos no embrião porque, por alguma razão desconhecida, mais células germinativas primordiais migram para o ovário esquerdo. Dessa forma, o ovário e o oviduto direito se degeneram, permanecendo apenas vestígios dessas estruturas na vida adulta ${ }^{[23,24]}$.

O ovário normalmente tem coloração branco-creme, mas pode ser parcial ou totalmente pigmentado. Fêmeas de cacatua alba, jandaia sol (Aratinga solstitialis) e 
arara Canindé (Ara ararauna) são os psitacídeos mais prováveis de terem ovários melanísticos.

No ovário de aves imaturas muito jovens, folículos não estão presentes, fazendo com que a diferenciação entre ele e um testículo se torne difícil. Cada ovário é achatado, e pode ser parecido com tecido adiposo. Ele pode ainda conter múltiplos sulcos em sua superfície, fazendo com que se pareça com um cérebro (Figura 5a). Já o ovário de uma fêmea imatura mais velha é consistente, e apresenta uma fina superfície granular com prematuro desenvolvimento folicular. A permanência do estado juvenil depende de cada espécie, da ave individualmente, da dieta e de condições do ambiente. Como regra geral, as gônadas aparecem maduras, nos periquitos australianos (Melopsittacus undulatus) e periquitos do gênero Agapornis, aos seis meses de idade. Porém, a maioria das aratingas (gêneros Aratinga, Nandayus, Pyrrhura) somente estará apta à procriação em dezoito meses a dois anos. Espécies do gênero Pionus, pequenas cacatuas (família Cacatuidae) e araras miniatura (gênero $\mathrm{Ara}$ ) podem iniciar a procriação entre dois e quatro anos, enquanto que os papagaios do gênero Amazona, papagaios cinza (gênero Psittacus), grandes cacatuas (família Cacatuidae), e araras (gênero Ara), entre três e seis anos. Psitacídeos domesticados parecem ir para o ninho e produzir ovos férteis mais cedo do que seus semelhantes selvagens ${ }^{[11]}$.

$\mathrm{Na}$ ave madura, quando se aproxima a época de procriação e a fêmea se torna sexualmente ativa, vários folículos apresentam rápido crescimento e maturação, e dão ao ovário a aparência de um cacho de uvas (Figura 5b). Isso é devido ao fato de numerosos folículos arredondados e de tamanhos variados se projetarem da superfície ventral do ovário ${ }^{[23,24,28]}$. A base do ovário maduro ainda contém muitos pequenos folículos e células responsáveis pela elaboração dos hormônios ovarianos ${ }^{[23,24]}$. Após a fase de atividade sexual, o ovário entra em fase de repouso, regredindo seu tamanho. Ele é então descrito como sendo maduro, mas inativo; contém vários pequenos folículos e tem a forma oval achatada e alongada, sendo a extremidade cranial arredondada e expandida transversalmente, e a caudal mais pontiaguda ${ }^{[12,28]}$. 


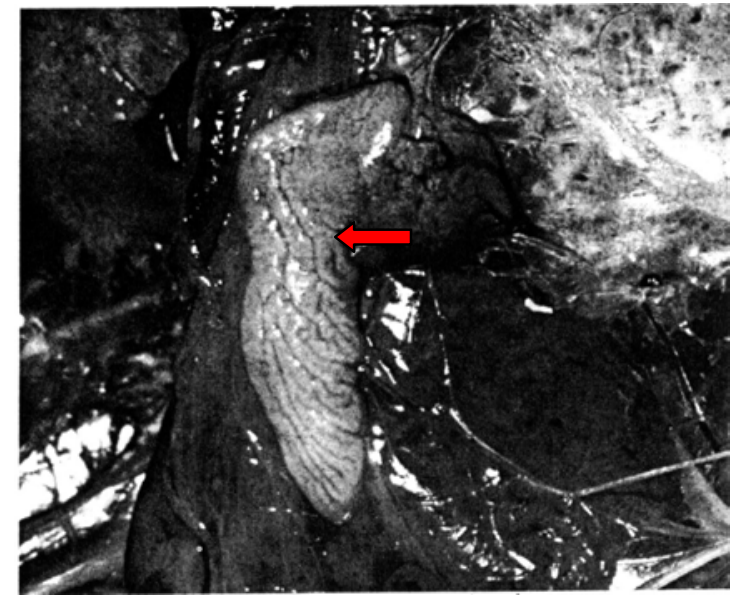

a)

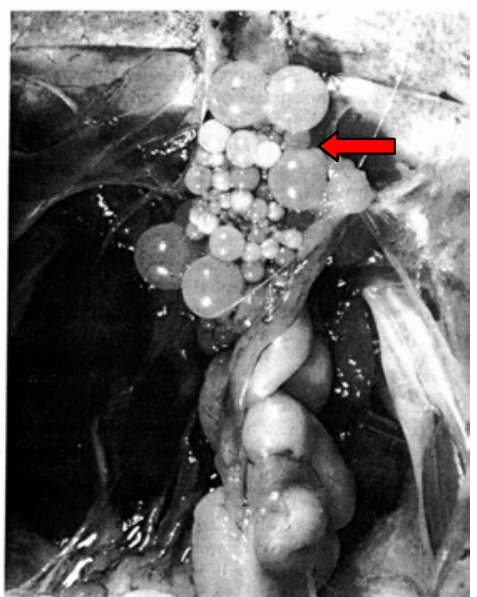

b)

Figura 5 - a) Ovário imaturo (seta); b) Ovário maduro em época reprodutiva, com folículos bem desenvolvidos, dando ao ovário a aparência de cacho de uvas (seta) ${ }^{[11]}$.

O oviduto, por sua vez, é um tubo convoluto, de parede espessa, que liga a cloaca ao celoma na vizinhança do ovário ${ }^{[28]}$. Durante a inatividade reprodutiva, ele é bastante fino, mas se torna longo, largo e retorcido durante uma postura de ovos ativa $^{[12]}$. De acordo com seu diâmetro externo, pregas da mucosa e glândulas, ele pode ser dividido anatomicamente em cinco regiões: infundíbulo, magno, istmo, útero e vagina ${ }^{[23,24,28]}$. O ovário produz a gema (óvulo), que é fabricada a partir de matérias-primas sintetizadas pelo fígado; o oviduto é que conduz a gema até a cloaca, adicionando a ela sucessivamente o albúmen, as duas membranas da casca e a casca (Figura 6) ${ }^{[28]}$.

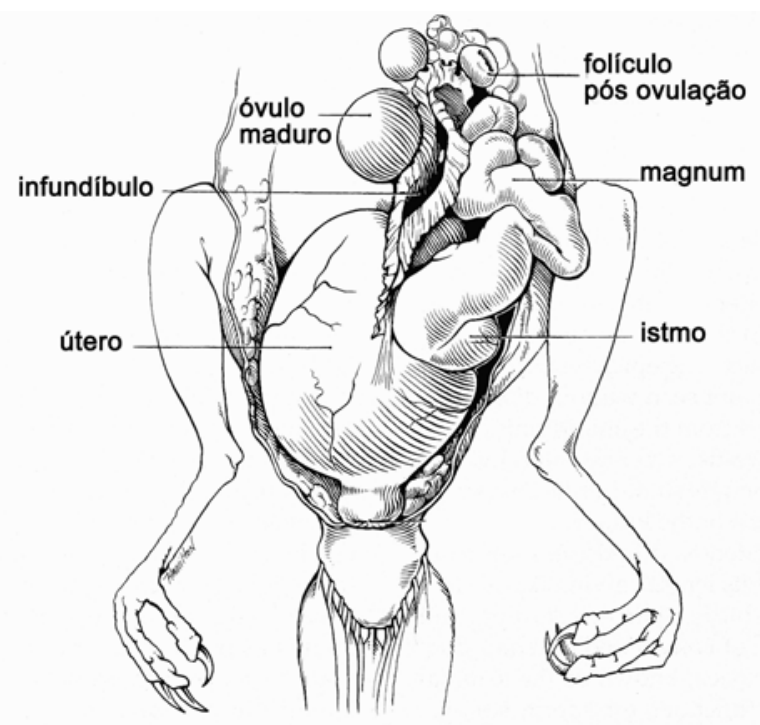

Figura 6 - Ovário e oviduto de periquito australiano maduro em época reprodutiva. No útero, observa-se a presença de um ovo ${ }^{[24]}$. 


\subsubsection{Rins}

Os rins direito e esquerdo estão simetricamente dispostos nos lados da coluna vertebral, em contato dorsalmente com a pelve e o sinsacro. Cranialmente estendem-se além da extremidade do sinsacro para atingir o pulmão; seus limites caudais quase atingem a extremidade caudal do sinsacro. $\mathrm{O}$ rim possui a forma de um retângulo alongado, e está dividido em três regiões de comprimento aproximadamente igual: a cranial (mais arredondada), a média (mais delgada) e a caudal (mais expandida e de formato irregular) (Figuras 2 e 4) ${ }^{[28]}$.

\subsubsection{Glândulas Adrenais}

As glândulas adrenais são amareladas, irregulares no seu contorno e se encontram craniais aos rins, em cada lado da veia cava caudal. As gônadas estão suspensas da parede dorsal do corpo sobre a mesma localização (Figuras 2 e 4) ${ }^{[24]}$.

O desenvolvimento do ovário esquerdo na fêmea oculta a adrenal esquerda; os testículos, por sua vez, parcial ou completamente, encobrem essas glândulas na vista ventral, até mesmo no estado de não-procriação. Em algumas aves, eles aumentam muito durante o ciclo de procriação, freqüentemente deslocando-as ${ }^{[23,24]}$. A extremidade cranial do epidídimo está incluída na cápsula da glândula adrenal, sendo essa associação particularmente extensa no epidídimo esquerdo ${ }^{[28]}$. 


\subsection{A Ressonância Magnética Nuclear (RMN)}

O fenômeno da ressonância magnética nuclear foi primeiramente observado em 1946, por Bloch e colaboradores ${ }^{[31]}$. Por mais de trinta anos, esse princípio físico foi utilizado na análise dos componentes de substâncias químicas. No início dos anos setenta, Damadian e Lauterbur, trabalhando independentemente, idealizaram a utilização do princípio de ressonância magnética para a obtenção de imagens, e desde as primeiras experiências clínicas de Holland et al., em 1980, o uso de imagens por RMN tem se tornado um importante método de diagnóstico em medicina humana e determinado a ampliação das possibilidades diagnósticas ${ }^{[32,33,34]}$.

\subsubsection{O Núcleo Atômico}

O átomo é composto por uma região central, o núcleo, onde estão os prótons e os nêutrons, e uma região mais externa, composta de uma "nuvem de elétrons" chamada eletrosfera (Figura 7). Os elétrons e os prótons têm a mesma carga elétrica, mas se comportam de maneira oposta; por isso, convencionou-se representar a carga elétrica do elétron com sinal negativo e a do próton, com positivo. Os nêutrons, por sua vez, não possuem carga elétrica ${ }^{[35]}$.

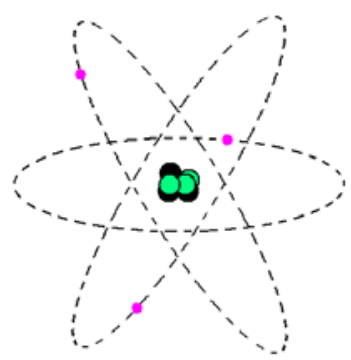

Figura 7 - Representação do átomo.

A desigualdade entre o número de prótons e de nêutrons no interior do núcleo (número ímpar de prótons e/ou nêutrons) é responsável pelo aparecimento do momento angular intrínseco do núcleo ou spin nuclear (onde o núcleo possui um movimento de rotação em torno de um de seus eixos), com um momento magnético associado ${ }^{[36]}$. Classicamente, esse momento magnético pode ser entendido como o resultado da rotação do núcleo atômico em torno de si mesmo, o qual possui uma 
carga elétrica distribuída em sua superfície. Essa carga, em movimento, gera uma corrente circular, que cria um campo magnético, representado pelo momento magnético ${ }^{[37,38]}$. Essa propriedade faz com que o núcleo se comporte como um pequeno ímã que gira em torno de seu próprio eixo, sem orientação definida ${ }^{[39]}$. Se não existe desigualdade entre o número de prótons e nêutrons, o momento é zero. Apenas aqueles átomos que apresentam número ímpar de prótons e/ou nêutrons terão a capacidade de produzir um sinal em RMN. Porém, apesar de uma grande quantidade de núcleos apresentar essa característica, somente um pequeno grupo tem utilidade em medicina, dentre eles os núcleos de ${ }^{1} \mathrm{H},{ }^{2} \mathrm{H},{ }^{13} \mathrm{C},{ }^{23} \mathrm{Na},{ }^{31} \mathrm{P}$ e ${ }^{19} \mathrm{~F}{ }^{[36]}$. O átomo de hidrogênio $\left({ }^{1} \mathrm{H}\right)$, que é altamente magnético e muito abundante no corpo humano (que contém grande quantidade de água, constituindo cerca de dois terços dos átomos), é o elemento mais utilizado em imagens de ressonância magnética $[40,41]$.

Sob a ação de um campo magnético estático (Bo), o momento magnético nuclear sofre um torque, que tende a alinhá-lo paralelamente a esse campo. Porém, associado ao momento magnético, existe um momento angular, que faz com que o momento magnético precessione em torno da direção do campo Bo ${ }^{[37,39]}$. Pode-se imaginar o comportamento dos núcleos como próximo ao de piões magnetizados, cujos pólos se situam nos extremos do seu eixo de rotação. As forças magnéticas produzidas pelo campo magnético Bo forçarão o pião a executar um movimento de precessão, de modo a que o movimento giratório da parte livre do seu eixo desenhe um cone no espaço (Figura 8$)^{[40]}$. Esse movimento de precessão é periódico e descrito pela equação de Larmor $^{[38]}$ : 
$\omega=\gamma \cdot \mathbf{B o}$

Onde:

$\omega=$ freqüência angular

Bo = campo magnético externo

$\gamma=$ constante de razão giromagnética

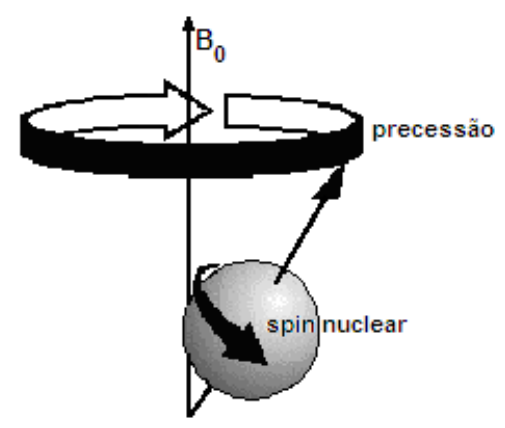

Figura 8 - Movimento de precessão do momento angular em torno do campo estático Bo ${ }^{[39]}$.

Para caracterizar esse movimento, pode-se medir quantas vezes por segundo o eixo completa a figura do cone, o que fornece a chamada freqüência de Larmor (freqüência angular ou freqüência de precessão) “ $\omega$ ”. Essa freqüência é específica para cada átomo. Dessa forma, os núcleos de hidrogênio em um campo magnético de $1,5 \mathrm{~T}$, por exemplo, ressonarão em uma freqüência de $64 \mathrm{MHz}^{[42]}$.

A freqüência de Larmor é diretamente proporcional à intensidade (valor escalar) do campo magnético aplicado "Bo", onde " $\gamma$ " é uma constante conhecida como razão giromagnética ${ }^{[40]}$. Os núcleos dos átomos, como descrito anteriormente, possuem momento angular e momento magnético que lhes conferem essa grandeza denominada constante de razão giromagnética. Cada elemento químico com spin não-nulo possui um $\gamma$ diferente, que o permite caracterizar ${ }^{[38]}$.

Quando a amostra é submetida a esse campo magnético estático Bo, os momentos magnéticos individuais precessionam em torno de Bo, orientados na direção do campo (paralela) ou oposta ao campo (antiparalela). Essas orientações correspondem a estados de menor ou maior energia do núcleo, respectivamente ${ }^{[42,43]}$. Entretanto, a situação de menor energia é privilegiada, ou seja, existem mais momentos magnéticos orientados paralelamente do que antiparalelamente, o que dá 
origem a uma magnetização $M$ na direção do campo Bo. Essa magnetização $M$ é gerada pelo somatório dos diversos momentos magnéticos dos núcleos presentes na $\operatorname{amostra}\left(\right.$ Figura 9) ${ }^{[43]}$.

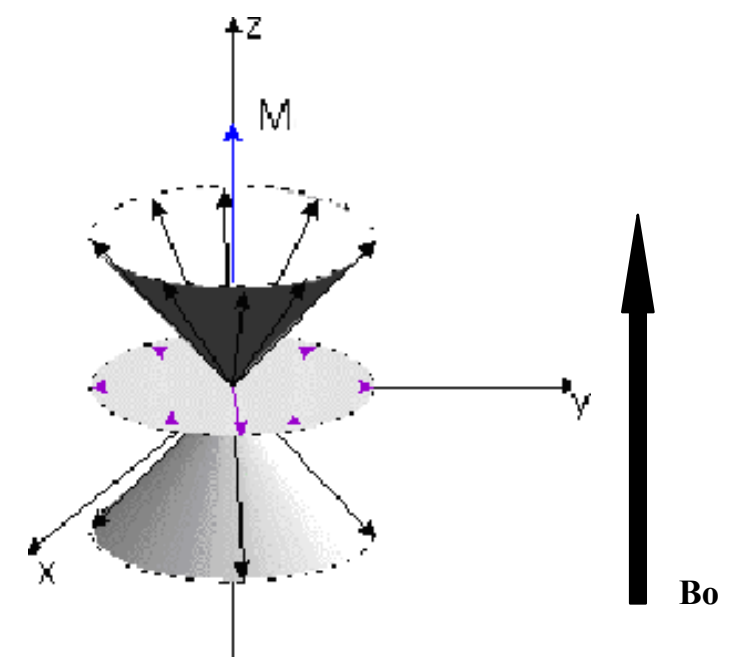

Figura 9 - Magnetização (M) gerada pela soma dos momentos magnéticos dos núcleos presentes na amostra ${ }^{[43]}$.

\subsubsection{O Fenômeno de Ressonância}

Para transformar a magnetização $\mathrm{M}$ em magnetização observável, é necessário que se retire o sistema do equilíbrio estabelecido ${ }^{[43]}$. Para remover essa condição de equilíbrio do sistema magnetizado, aplica-se, sob a forma de um pulso, um segundo campo magnético B1 no plano perpendicular a $\mathrm{Bo}^{[40]}$.

Aplicando-se esse segundo campo magnético B1, oscilando na mesma freqüência de precessão (freqüência de Larmor) dos núcleos e com orientação perpendicular a Bo, B1 e os núcleos trocarão energia, e esse fenômeno de troca de energias entre os núcleos e o campo oscilante B1 é denominado ressonância ${ }^{[38]}$. Para a maioria dos núcleos e para campos magnéticos Bo da ordem de mil a dez mil Gauss, a freqüência de Larmor fica na faixa de radiofreqüência $(R F){ }^{[40]}$. Para se obter esse campo magnético oscilante B1 na freqüência de Larmor, coloca-se a amostra dentro de uma bobina, capaz de gerar um campo eletromagnético na faixa de radiofreqüência, perpendicular a $\mathrm{Bo}^{[37]}$.

No equilíbrio térmico, o vetor de magnetização $\mathrm{M}$ aponta ao longo de $\mathrm{B}$, porém, após a aplicação do campo magnético oscilante $\mathrm{B}$ 1, parte da magnetização $\mathrm{M}$ 
é transferida para o plano transversal (formando com a direção de Bo um ângulo $\alpha$ ), e irá precessionar nesse plano, com freqüência de Larmor [37,43]. Como a magnetização M nada mais é do que um pequeno ímã, ocorrerá variação de fluxo de campo magnético no interior da bobina de RF (bobina com eixo perpendicular ao campo estático) e, segundo a Lei de Faraday, gerando uma força eletromotriz (na freqüência de Larmor) nos terminais da mesma ${ }^{[31,39]}$. O sinal detectado pela bobina receptora é universalmente denominado FID, proveniente do termo em inglês Free Induction Decay, que significa a precessão livre dos spins após o pulso de $\mathrm{RF}^{\left[{ }^{[31}\right]}$. O FID decai exponencialmente com o tempo. Esse decaimento é caracterizado por um fenômeno denominado relaxação ${ }^{[43]}$.

A mesma bobina utilizada para estabelecer o campo oscilante B1 servirá agora para captar os sinais fracos, induzidos pela magnetização transversal e chamados sinais de RMN, passíveis de observação e mensuração ${ }^{[40]}$.

Como dito anteriormente, terminada a ação do pulso, a magnetização $\mathrm{M}$ formará, com a direção de Bo, um ângulo $\alpha$, que dependerá da intensidade de Bo e do tempo de aplicação do pulso ${ }^{[40]}$. Dessa forma, o ângulo $\alpha$, denominado ângulo de excitação, pode ser ajustado de $90^{\circ}$ (pulsos de $\pi / 2$ ), $180^{\circ}$ (pulsos de $\pi$ ) ou qualquer outro valor que for preciso (Figura 10) ${ }^{[37]}$.

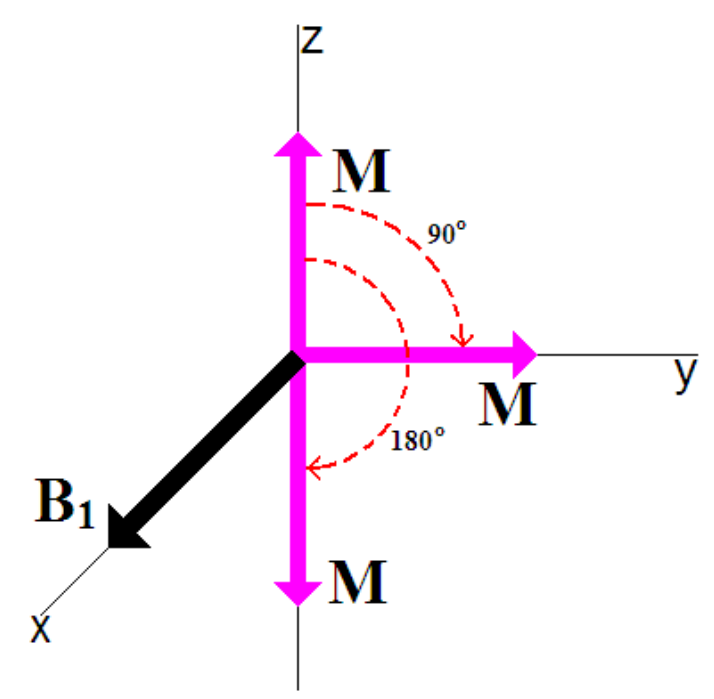

Figura 10 - Demonstração dos pulsos de $\pi / 2$ e $\pi$, que provocam, respectivamente, rotação de 90 e de 180 graus na magnetização $M$. 


\subsubsection{Relaxação}

Após a aplicação do pulso de radiofreqüência, o sistema de spins é retirado de uma situação de equilíbrio ( $\mathrm{M}$ ao longo de Bo) para uma situação de nãoequilíbrio (parte da magnetização $\mathrm{M}$ é transferida para o plano transversal). Naturalmente, o sistema irá procurar restabelecer a situação de equilíbrio. Esse retorno ao equilíbrio envolve dois mecanismos distintos, denominados relaxação transversal, caracterizado por um tempo de relaxação $T_{2}$, e relaxação longitudinal, caracterizado por $\mathrm{T}_{1}{ }^{[43]}$.

No caso de uma amostra contendo $10^{23}$ núcleos atômicos com spin diferente de zero, não existe somente uma freqüência de Larmor para spins de mesma espécie. Isso ocorre devido à variação de campo magnético ao longo da amostra, decorrente ou dos campos magnéticos produzidos pelos próprios momentos magnéticos dos núcleos atômicos, entre outras interações, ou porque o campo magnético estático aplicado não é homogêneo. Desse modo, o campo magnético na direção z varia ao longo da amostra, induzindo variações nas freqüências de Larmor. Portanto, a magnetização transversal produzida imediatamente após um pulso de radiofreqüência (RF) será constituída por várias magnetizações $m$, que irão precessionar com freqüências de Larmor diferentes, no plano transversal. Conseqüentemente, a magnetização total tenderá a desaparecer ao longo do tempo, devido ao espalhamento total dos spins no plano transversal. Como o sinal de RMN corresponde à variação de fluxo de campo magnético produzido pela magnetização total $\mathrm{M}$, composta pelos diferentes grupos de spins com freqüências de precessão diferentes $m$, o FID deverá tender a zero depois de um intervalo de tempo, denominado tempo de relaxação transversal $\left(\mathrm{T}_{2}\right)^{[31]}$.

Por outro lado, a relaxação longitudinal exprime o fato de que a magnetização, uma vez trazida ao plano transversal pelo pulso de radiofreqüência (RF), lentamente volta ao equilíbrio térmico, alinhando-se novamente ao longo do campo magnético $\mathrm{Bo}$, na direção $\mathrm{z}^{[37]}$. Para isso ocorrer, os spins necessitam se dispor da energia que receberam do pulso, e isso é feito pela troca de energia com a vizinhança local, denominada REDE. A eficiência da relaxação, basicamente está associada a quão hábil é a rede em produzir campos locais flutuantes perpendiculares 
a Bo, na região de cada núcleo com freqüências características próximas à freqüência de Larmor. Além disso, a amplitude desses campos locais também influenciará na relaxação longitudinal. Como a relaxação longitudinal depende, basicamente, de como o sistema de spins interage com a rede, ela também recebe o nome de relaxação spin-rede. A volta da magnetização longitudinal é exponencial, tendo, portanto, uma constante de tempo que a caracteriza e que se denomina tempo de relaxação longitudinal $\left(\mathrm{T}_{1}\right)$. Do ponto de vista dos tempos de relaxação, tem-se a condição $T_{2} \leq T_{1}$. Isso acontece porque, para recuperar a magnetização longitudinal, é necessário, antes de tudo, destruir a magnetização transversal ${ }^{[43]}$.

\subsubsection{Seqüências de Pulso}

No estudo de RMN, são colhidas várias centenas de sinais, de forma que o estudo geralmente consiste em uma série de eventos com a seguinte ordem: pulso de radiofreqüência $(\mathrm{RF})$, leitura, aguardar. Cada série é uma repetição da precedente na ordem e momento dos pulsos de RF usados. A combinação específica é denominada seqüência de pulso de $\mathrm{RF}^{[42]}$. As seqüências de pulsos de RF, também chamadas de técnicas, podem ser as mais variadas, tais como saturação parcial, inversion recovery, gradient-eco, chemical-shift e spin-eco ${ }^{[32]}$.

Essa seqüência denominada de spin-eco é utilizada para estudar o fenômeno de relaxação transversal dos efeitos das inomogeneidades do campo estático. Após o pulso de RF que excita os núcleos da amostra, aguarda-se um pequeno período para evolução dos processos de relaxação. Em seguida, um novo pulso de RF, que muda a orientação da magnetização em $180^{\circ}$, altera a posição de todos os spins excitados, mantendo, porém, a mesma direção, o sentido e a velocidade angular de precessão. Ao fim de um tempo igual ao da espera entre o pulso de excitação $\left(90^{\circ}\right)$ e o pulso de refocalização $\left(180^{\circ}\right)$, os núcleos recuperarão a coerência de fase, resultando em um novo incremento da magnetização no plano xy. Esse novo sinal é denominado eco. O intervalo de tempo decorrido entre o pulso inicial de excitação e o pico de refocalização de eco de spins se denomina tempo ao eco (TE); o intervalo de tempo decorrido entre dois diferentes pulsos de excitação se denomina tempo de repetição $(\mathrm{TR})^{[38]}$. 


\subsubsection{Tomografia por Ressonância Magnética Nuclear - TRMN}

\subsubsection{Introdução}

A tomografia por ressonância magnética nuclear (TRMN) é um método de diagnóstico por imagem, baseado nas propriedades magnéticas naturais dos núcleos atômicos. As imagens podem ser obtidas em cortes tomográficos de qualquer plano do corpo (axial, coronal e sagital), sem que haja a necessidade de mudar o paciente de posição ${ }^{[32,40,44]}$. Ela tem se firmado como modalidade diagnóstica de alta sensibilidade e excelente contraste de partes moles ${ }^{[45,46,47,48]}$. Esta sua capacidade multiplanar de obtenção de imagens e alta resolução de contraste, são muito superiores às da tomografia por raios $\mathrm{X}^{[34]}$. Segundo ABDO et al. ${ }^{[49]}$, a ressonância magnética produz imagens altamente claras e detalhadas do cérebro humano, sendo possível a localização e a caracterização de estruturas normais e patológicas. Além disso, é um método não-invasivo, e que não utiliza radiação ionizante. Diferentemente dos métodos radiográficos convencionais que utilizam radiação eletromagnética de alta freqüência (raios $\mathrm{X}$ ), a ressonância magnética usa radiação de freqüência muito menor (na faixa de radiofreqüência), e portanto, não oferece riscos biológicos ${ }^{[38,44]}$. Ao contrário dos métodos tradicionais de aquisição de imagens diagnósticas, como a radiografia convencional e a tomografia por raios $\mathrm{X}$ (fundamentalmente métodos de transmissão), a TRMN se compara à ultra-sonografia como método de emissão-resposta, ou seja, a amostra a ser analisada é submetida a dado estímulo magnético e, segundo seu comportamento, emite um sinal em resposta, a ser processado pelo equipamento.

Utilizada desde o seu início na obtenção de imagens de doenças do sistema nervoso, a TRMN, por meio de novos desenvolvimentos técnicos, estendeu-se também para outros sistemas do corpo humano ${ }^{[32]}$.

Apenas aqueles indivíduos que possuem marcapasso cardíaco ou outros tipos de implantes estimulativos, eletrônicos, ou qualquer outro dispositivo que contenha em sua estrutura metal ferromagnético, incluindo clipes vasculares, placas, pinos ósseos de sustentação, entre outros, não podem ser submetidos ao exame de TRMN, devido ao forte campo magnético do tomógrafo. Dessa mesma forma, 
utensílios tais como relógios, pontes dentárias, cartões magnéticos (os quais poderiam ter seus códigos magnéticos inutilizados), devem ser retirados antes da realização do exame ${ }^{[50]}$.

\subsubsection{A TRMN na Medicina Veterinária}

Do mesmo modo que a medicina humana torna-se tecnologicamente mais avançada, a medicina veterinária também caminha para este progresso. Isso pode ser notado nos vários testes e procedimentos avançados, antes apenas usados em humanos, e que agora estão acessíveis aos animais ${ }^{[51]}$. Dessa forma, modernas técnicas de imagem têm se tornado, de modo crescente, comum no meio veterinário, de países de primeiro mundo, com vários centros oferecendo exames de ressonância magnética, tomografia computadorizada e medicina nuclear. Esse desenvolvimento tem resultado em diagnósticos mais precisos (particularmente de doenças neurológicas), auxiliando em melhor tratamento e prognóstico mais correto ${ }^{[52]}$.

Embora a TRMN em pesquisa e clínica médica veterinária seja relativamente recente, necessitando ser mais explorada, já vem sendo utilizada com sucesso no diagnóstico de desordens do cérebro, cordão espinhal, articulações, tecidos moles, abdômen e pélvis em diversas espécies animais ${ }^{[53,54,55,56]}$.

Vários trabalhos relatam o uso da TRMN na medicina veterinária. Ela tem sido usada para descrever a anatomia normal do cérebro ${ }^{[33]}$ e do olho canino ${ }^{[57]}$, do cérebro ${ }^{[58]}$, do abdômen ${ }^{[59,60]}$ e do ouvido médio felino ${ }^{[61]}$ e do cérebro eqüino ${ }^{[62,63,64]}$, entre outros. Também tem sido usada para descrever patologias, tais como fraturas do processo palmar ${ }^{[65]}$ e síndrome navicular em eqüinos ${ }^{[66]}$, tumores nasal e espinhal em felinos ${ }^{[67,68]}$, doenças orbitais em pequenos animais ${ }^{[69,70]}$, e em caninos, tumores nasais, espinhais e cerebrais ${ }^{[67,71,72,73,74]}$, degeneração esponjosa do SNC ${ }^{[75]}$, mielopatia estenótica cervical ${ }^{[76]}$, estenose degenerativa lombossacra ${ }^{[77,78]}$, discoespondilite ${ }^{[79,80]}$ e otite média ${ }^{[81,82]}$, entre muitas outras patologias.

No que diz respeito a TRMN em medicina de aves, pouca pesquisa tem sido feita para avaliar o seu uso nesses animais ${ }^{[83,84]}$. Encontram-se estudos que relatam o uso de imagens por ressonância magnética do cérebro e cavidade celomática de pombas domésticas ${ }^{[83]}$, do cérebro do canário e do estorninho europeu ${ }^{[85]}$, do olho e 
órbita normais de coruja ${ }^{[86]}$, do acúmulo de tecido intracranial em patos domésticos ${ }^{[87]}$, de psitacídeos com sinusite crônica ${ }^{[84]}$, de papagaios cinza para a mensuração da traquéia ${ }^{[88]}$, e mais recentemente, dos órgãos reprodutivos de pássaros canoros ${ }^{\left[{ }^{89]}\right.}$.

Para ROMAGNANO et al. ${ }^{[83]}$, embora a radiografia convencional seja uma importante modalidade de imagem em diagnóstico aviário, a avaliação de estruturas abdominais é freqüentemente impedida por pobre detalhe da cavidade celomática, necessitando de estudo com o uso de contraste gastrintestinal. Além disso, a avaliação radiográfica do cérebro e cordão espinhal de aves é raro, pois angiografia cerebral é impraticável, e mielografia é difícil. Por sua vez, a ultra-sonografia abdominal de aves muitas vezes é de valor limitado, devido ao extenso sistema de sacos aéreos e limitada presença de janelas acústicas. Em contrapartida, o uso da TRMN em aves oferece várias vantagens sobre a radiografia convencional e tomografia computadorizada, incluindo imagem multiplanar, ausência de radiação ionizante e melhor resolução de contraste de tecidos moles. Conseqüentemente, a TRMN tem substituído a tomografia computadorizada para a avaliação de anormalidades de tecidos moles e muitas desordens do sistema nervoso central, tanto em humanos quanto em animais.

\subsubsection{Formação de Imagens}

O estudo de imagens por ressonância magnética observado em uma tela de computador e/ou filme é uma tradução para o formato visual de valores numéricos residentes na memória do equipamento. Os valores numéricos que formam a imagem são denominados pixéis (elementos de imagem). Esses valores são gerados a partir de sinais de RMN, em que é utilizado um processo matemático denominado transformada de Fourier, para converter a informação de freqüência contida no sinal de cada localização no plano estudado aos níveis de intensidade correspondentes, e estes, então, são exibidos em tons de cinza, em uma disposição de matriz de, por exemplo, 256 × 256 pixéis.

A intensidade do pixel exibido é proporcional ao seu valor numérico, e reflete a intensidade acumulativa do sinal de radiofreqüência recebido de uma localização correspondente dentro do corte de tecido examinado. 
Qualquer estudo de TRMN mostra diretamente a amplitude do sinal recebido como função da posição. Para um determinado pixel, a amplitude depende de $\mathrm{T}_{1}, \mathrm{~T}_{2}$ e da densidade protônica da substância em estudo ${ }^{[42]}$.

\subsection{Gradientes}

Em uma amostra extensa (tridimensional) como o corpo humano, as imagens obtidas pelos equipamentos de RMN podem ser bidimensionais (em fatias tomográficas, como na tomografia computadorizada por raios $\mathrm{X}$ ) ou tridimensionais (volumétricas).

Para a obtenção de fatias bidimensionais em um corpo, é necessário a localização de cada fatia ao longo do eixo escolhido para representação, e também de cada volume (voxel) responsável pela emissão do sinal que cada ponto (pixel) representa na matriz de imagem ${ }^{[38]}$.

A localização do sinal de uma amostra extensa se dá a partir da implementação de um gradiente de campo magnético ao longo do eixo de representação ${ }^{[38]}$. Esse campo de gradiente é superposto ao campo magnético principal ${ }^{[42]}$.

Pela equação de Larmor, sabe-se que a freqüência de ressonância é proporcional à intensidade do campo magnético aplicado. Em um gradiente de campo magnético, cada ponto ao longo do eixo do gradiente apresentará uma intensidade de campo diferente. Núcleos iguais colocados em pontos diferentes ao longo do gradiente apresentarão, portanto, freqüência de ressonância diferentes ${ }^{[38]}$.

Em uma imagem bidimensional, "tomográfica", a fatia selecionada é submetida a dois outros gradientes de localização perpendiculares entre si ao longo da fatia. O primeiro gradiente codificará espacialmente a freqüência ao longo de sua orientação e o segundo, as fases dos sinais. Assim, cada volume componente da fatia (voxel) estará codificado em duas dimensões (através da fase e da freqüência dos sinais), e seus sinais reconstruídos em uma matriz de pontos (imagem), após seu processamento por uma transformada de Fourier. A codificação de fases se dá pela aplicação do gradiente tantas vezes quantas forem necessárias para a construção da matriz ${ }^{[38]}$. 
Assim sendo, a localização espacial em TRMN é obtida pela aplicação de um campo magnético espacialmente dependente, denominado gradiente, e a amplitude e direção desse gradiente podem ser selecionadas pelo usuário ${ }^{[42]}$.

\subsubsection{Aspectos Tomográficos de Amostras}

Imagens de TRMN são intensamente utilizadas no diagnóstico médico. Para se distinguir um tecido patológico de um tecido normal, a imagem da região de interesse precisa apresentar contraste entre os dois tecidos ${ }^{[37]}$.

Uma imagem por ressonância magnética nuclear é, na verdade, um mapa da magnetização transversal ao longo de toda amostra. Como os tecidos geralmente possuem diferentes quantidades de núcleos de hidrogênio (diferentes quantidades de água), tecidos distintos aparecerão contrastados na imagem. A esse tipo de contraste se denomina contraste por densidade. Entretanto, a magnetização transversal não depende somente da quantidade de spins presentes em cada tecido, mas também dos tempos de relaxação dos mesmos. Se na imagem as diferenças de intensidade no sinal (o que na imagem aparecem como diferenças de brilho) se devem a diferenças entre os tempos de relaxação $T_{2}$ dos tecidos, então se diz que o contraste é por $T_{2}$. Já no caso em que os tecidos são distinguidos pela diferença no tempo de relaxação $T_{1}$, o contraste é por $T_{1}$. A definição do contraste depende da técnica utilizada e da temporização do experimento (TE e TR). Na técnica de spin eco (uma das mais utilizadas técnicas de tomografia, pela sua facilidade de controlar o contraste na imagem), o contraste pode ser por $\mathrm{T}_{1}, \mathrm{~T}_{2}$ ou densidade, dependendo da temporização do experimento ${ }^{[37,43]}$.

Em uma seqüência spin eco, se o tempo de repetição é curto, os spins com $\mathrm{T}_{1}$ mais longos não têm tempo para recuperar a magnetização de equilíbrio antes da próxima excitação, o que acontece com aqueles spins que possuem $T_{1}$ mais curtos. Desse modo, a magnetização longitudinal, e conseqüentemente a magnetização transversal daqueles spins com $\mathrm{T}_{1}$ mais curto, será maior que a dos spins com $\mathrm{T}_{1}$ mais longo. Para minimizar a influência dos tempos de relaxação $T_{2}$ na amplitude do eco, define-se o mais curto possível tempo ao eco, e o contraste neste caso será 
predominantemente por $T_{1}$. Se o contraste é por $T_{1}$, spins que possuem $T_{1}$ mais curto aparecerão mais brilhantes na imagem.

Para obter contraste por $\mathrm{T}_{2}$ na técnica spin eco, é necessário, antes de mais nada, eliminar a influência de $T_{1}$ na amplitude do sinal. Para isso, utilizam-se tempos de repetição longos, a fim de que, mesmo os spins com tempos de relaxação bastante longos, recuperem toda a magnetização longitudinal antes da excitação seguinte. Além disso, o tempo ao eco também deve ser longo para que haja bastante influência de $\mathrm{T}_{2}$ na amplitude do eco. Spins com $\mathrm{T}_{2}$ mais longos aparecerão mais brilhantes nas imagens.

No contraste por densidade, procura-se minimizar os efeitos de $T_{1}$ e $T_{2}$ na amplitude do sinal, o que se consegue fazendo o tempo de repetição longo e o tempo ao eco curto (Figura 11) ${ }^{[43]}$.
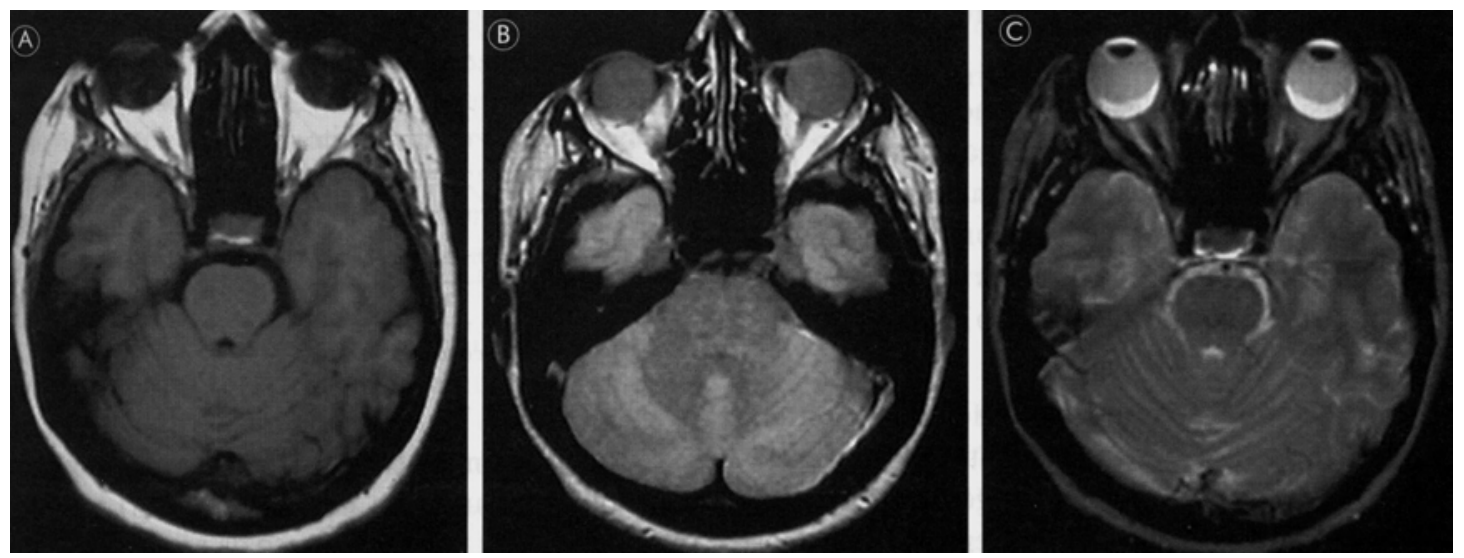

Figura 11 - Imagens axiais de crânio, sendo: A - ponderada por T1, B - ponderada por densidade de próton, $\mathrm{C}$ - ponderada por $\mathbf{T} 2{ }^{[38]}$. 


\subsubsection{Instrumentação}

\subsection{Magnetos}

Os magnetos utilizados em tomógrafos de ressonância magnética nuclear podem ser permanentes, resistivos ou supercondutores.

1 - Magnetos permanentes são constituídos de alnico, cerâmicas ou terras raras. Funcionam como ímãs permanentes e podem atingir intensidade de campo de até $0,3 \mathrm{~T}$.

2 - Magnetos resistivos são eletroímãs construídos com bobinas através das quais circula a corrente elétrica que gera o campo magnético. Tais magnetos, em geral, operam na faixa de até $0,4 \mathrm{~T}$.

3 - Magnetos supercondutores (tipo de magneto utilizado neste trabalho) são também construídos com bobinas de ligas especiais, geralmente nióbio-titânio, as quais, quando resfriadas a cerca de 10-14K, perdem abruptamente a resistência ao fluxo de corrente com um mínimo de dissipação. Devido às condições térmicas peculiares para manutenção da supercondutividade, essas bobinas são imersas em hélio líquido, demandando sua reposição periódica. Produzem campos extremamente homogêneos e de grande intensidade, possibilitando melhor relação sinal-ruído. Para imagens médicas, utilizam-se magnetos de $0,5-2,0 \mathrm{~T}^{[38]}$.

A intensidade de sinal em ressonância magnética nuclear depende, em parte, da intensidade do campo magnético produzido pelo magneto. KÄRKKÄINEN ${ }^{\text {[33] }}$ considera aparelhos com campos menores que $0,1 \mathrm{~T}$ como campo ultrabaixo, de 0,1 a 0,3T, campo baixo, 0,35 a 0,6T, campo médio e 1 a $2 \mathrm{~T}$, campo alto.

Os campos magnéticos principais nem sempre possuem homogeneidade suficiente para a obtenção de imagens de qualidade. Para sua otimização (shimming), são empregadas bobinas eletromagnéticas, também conhecidas como bobinas de shimming ${ }^{[38]}$. 


\subsection{Gradientes}

Para obtenção dos gradientes de localização espacial, são utilizados três pares ortogonais de bobinas. A aplicação conjunta de dois pares permite a obtenção de gradientes não-ortogonais empregados na aquisição de imagens oblíquas.

A amplitude dos gradientes limita a espessura da fatia representada, por definir as diferentes freqüências de ressonância ao longo de sua orientação ${ }^{[38]}$.

\subsection{Bobinas de RF}

As bobinas de transmissão e recepção do sinal de RF podem apresentar diversas geometrias: solenóides, gaiolas ou espiras simples ${ }^{[38]}$.

Os sinais obtidos pela bobina que anteriormente excitou os núcleos são amplificados e detectados pelo receptor de baixo ruído, que provê um sinal ao sistema de aquisição, capaz de digitalizá-lo, armazená-lo e posteriormente processálo. Todo o sistema de geração e aquisição de dados é controlado por um sistema de computação, que finalmente, a partir do processamento dos sinais obtidos, fornece a imagem final ${ }^{[40]}$.

Dessa forma, um sistema de RMN capaz de gerar imagens in vivo do interior do corpo conta com um magneto principal, um sistema gerador dos gradientes de campo magnético, um sistema de computação e um conjunto de dispositivos que manejam a radiofreqüência (gerador, transmissor, receptor/demodulador e bobinas de excitação e recepção) ${ }^{[40]}$. 


\subsection{Contenção de Aves Silvestres}

Existem dois tipos de contenção em medicina veterinária, a contenção física ou mecânica e a contenção farmacológica ou química. O método de contenção utilizado deve garantir a plena segurança do paciente, da equipe envolvida, e deve ainda permitir a realização adequada do procedimento médico ou de manejo proposto [90].

\subsubsection{Contenção Física}

Segundo PACHALY (apud MANGINI, 1998, p.9) ${ }^{[90]}$, a contenção física se baseia no confinamento do animal que se pretende conter, na restrição de seus movimentos defensivos e, finalmente, na subjugação do paciente, permitindo a captura e acesso seguro a seu corpo. Ela normalmente antecede a contenção química, a não ser, por exemplo, no caso dos mamíferos, em que se pode fazer uso de equipamentos, como pistolas e zarabatanas, para a imobilização química à distância.

A contenção física causa grande estresse em aves silvestres. Segundo CRUZ [91], esse estresse gera uma grande liberação de catecolaminas (adrenalina e noradrenalina), o que faz aumentar a freqüência cardíaca. Conseqüentemente, o fluxo de sangue no átrio e ventrículo é reduzido, resultando em diminuição do débito cardíaco e pressão arterial. Há aumento na demanda de oxigênio no coração devido ao seu grande esforço, causando hipoxia cerebral, que pode levar o animal a óbito. A excitação do animal também é prejudicial quando se aplicam agentes anestésicos, uma vez que a liberação de catecolaminas sensibiliza o miocárdio de tal forma, que torna a medicação anestésica fatal ${ }^{[91,92]}$.

Portanto, o conhecimento da espécie que se deseja conter, quanto a sua biologia, o seu comportamento em situações de perigo (atentando ao fato se esse animal apresenta postura de ataque, defesa ou fuga, e as armas que ele pode utilizar, como unhas, bico etc.) e a melhor forma para a sua contenção são pré-requisitos importantes para minimizar o estresse do animal, e também garantir a segurança do profissional e/ou da equipe envolvida. Dessa forma, existem diversos métodos de 
contenção física para as diferentes espécies de aves. A Figura 12 demonstra as formas de contenção para os psitacídeos.
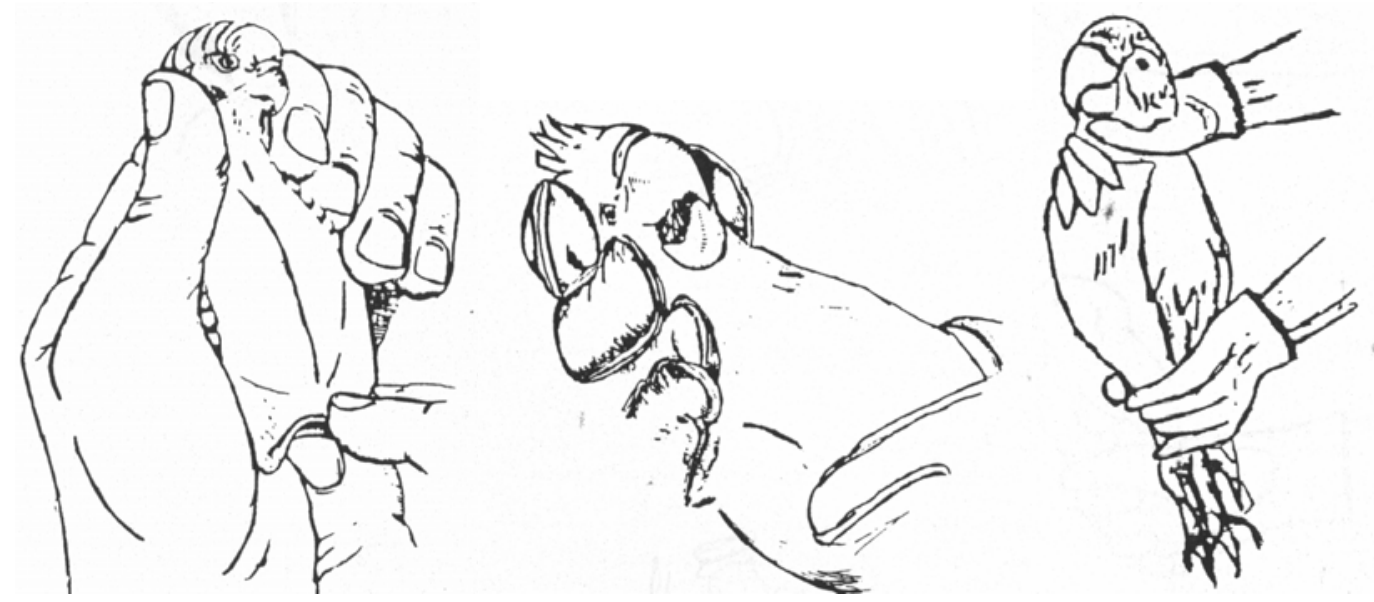

Figura 12 - Demonstração das diferentes formas de contenção física para os psitacídeos ${ }^{\text {[91] }}$.

\subsubsection{Contenção Farmacológica}

\subsubsection{Aspectos Gerais}

Segundo PACHALY (apud MANGINI, 1998, p.11) ${ }^{[90], ~ a ~ c o n t e n c ̧ a ̃ o ~}$ química ou farmacológica consiste na administração de fármacos anestésicos ou tranqüilizantes, geralmente não se buscando a anestesia geral, mas sim um estado de imobilidade que permita a realização de um procedimento médico ou de manejo mais prolongado, minimizando o estresse do paciente e oferecendo segurança para o animal e para a equipe. NICOLAU \& SPINOSA ${ }^{[93]}$ relataram que a contenção química traz conforto e tranqüilidade para o animal, além de abolir a sua agressividade.

Nos últimos anos, não somente devido ao aumento de interesse na conservação da vida silvícola, mas também pelo crescente hábito de manter aves como animais de companhia, cresceu a demanda para contenção e anestesia desses animais. Dessa forma, o desenvolvimento dos agentes imobilizantes se constituiu em uma das grandes contribuições para a medicina veterinária, ao permitir a aproximação desses animais para a realização de várias intervenções, como exames, coleta de material e tratamento ${ }^{[93]}$. 
Considerações gerais que devem ser levadas em conta na escolha de um agente anestésico para aves incluem: segurança a curto e longo prazo para o paciente e para o pessoal de suporte, tranqüilidade na administração (mínimo estresse), controle da dosagem, rápida indução e recuperação, adequada contenção para o procedimento desejado e alto índice terapêutico ${ }^{[93,94,95]}$.

Segundo NICOLAU \& SPINOSA ${ }^{[93]}$, a prática comum para conter e/ou anestesiar aves está centrada em procedimentos de curta duração, e as vias mais utilizadas são a respiratória e a parenteral, em particular a intramuscular, em que ambas apresentam vantagens e desvantagens. A administração anestésica por via respiratória tem a vantagem de ser rápida e segura, porém tem o inconveniente de reter o fármaco gasoso nos sacos aéreos, podendo gerar um aprofundamento anestésico não desejado. Além disso, requer equipamento adequado, nem sempre disponível. A administração anestésica por via intramuscular, apesar de aumentar o período de recuperação dos animais devido ao maior tempo de permanência do anestésico no organismo, é a mais indicada para o uso em aves de pequeno porte, uma vez que a punção venosa é mais difícil de ser obtida. STEINER JR. \& DAVIS [96] também afirmam que os agentes anestésicos injetáveis geralmente são aplicados em aves por via intramuscular (nos músculos peitorais).

A rotina hospitalar veterinária indica que os anestésicos injetáveis são mais utilizados, principalmente tendo-se em vista o custo da aparelhagem para anestesia inalatória e a necessidade de um profissional experiente para o seu manuseio. Baseado nisso, cada vez mais são apresentadas novas associações anestésicas injetáveis, visando diminuir os efeitos tóxicos de altas doses de agentes isolados. Outra vantagem dos anestésicos injetáveis é o fato de começarem a agir logo após a sua administração. Por outro lado, o tempo de recuperação depende da biotransformação e excreção do agente pelo organismo, podendo ser, às vezes, bastante prolongado ${ }^{[93]}$.

Segundo HARRISON ${ }^{[94,95]}$, os agentes anestésicos recomendados para aves em estado crítico são, em ordem decrescente de segurança, o isofluorano (anestesia inalatória), a quetamina e xilazina combinadas por via intravenosa, a quetamina e xilazina combinadas por via intramuscular, o halotano (anestesia inalatória) e o metoxifluorano (usado somente com vaporizador apropriado). HARRISON [94] 
também ressalta que os agentes anestésicos, para uso em aves, mais comumente relatados na recente literatura são a quetamina sozinha, a combinação de quetamina e xilazina, a combinação de quetamina e diazepam, o halotano, o metoxifluorano, os dois anteriores em combinação com óxido nitroso e o isofluorano.

\subsubsection{Cloridrato de Quetamina}

O cloridrato de quetamina é um agente anestésico dissociativo, capaz de dissociar o córtex cerebral de maneira seletiva, produzindo um estado de sedação, analgesia, imobilidade, amnésia e "desligamento", sem perda, porém, dos reflexos protetores. $\mathrm{O}$ indivíduo experimenta forte sensação de estar dissociado do meio ambiente. A anestesia dissociativa é caracterizada como um estado de alteração do sistema nervoso central (SNC), envolvendo tanto a estimulação como a depressão. Esses efeitos centrais incluem excitação, ataxia, catalepsia, anestesia e até convulsões. As manifestações da estimulação do SNC podem ocorrer tanto em doses altas como em doses baixas do anestésico ${ }^{[93,97]}$.

Os anestésicos dissociativos não produzem relaxamento muscular, sendo observado o oposto, ou seja, aumento do tônus muscular, às vezes ocorrendo até movimentos despropositados e respostas violentas aos estímulos. Por causa destes e mais alguns efeitos, é comum associá-los com outros agentes para se reduzir ou abolir as reações indesejáveis ${ }^{[93]}$. Apesar de boa analgesia proporcionada por essa droga, ela não permite efetuar laparotomias ou toracotomias, pois, para esse fim, a dose recomendada seria superior a $100 \mathrm{mg} / \mathrm{kg}$, o que torna essa anestesia impraticável, devido a seus riscos e onerosidade; entretanto, seu uso é prático para intervenções rápidas ${ }^{[97]}$.

\subsubsection{Cloridrato de Xilazina}

Apesar de o cloridrato de xilazina exercer atividades analgésica e sedante, ele se caracteriza por sua ação acentuadamente miorrelaxante em nível meduloespinhal, sendo usado em grande escala para a contenção farmacológica em animais silvestres ${ }^{[98]}$. 
Seu uso isolado pode causar bradicardia e bloqueio parcial atrioventricular, diminuição da freqüência respiratória e tremores musculares ${ }^{[96,99]}$. O tempo de recuperação é prolongado; quase sempre há excitação e até mesmo severas convulsões durante a indução, em algumas espécies. Embora a dose letal seja de aproximadamente dez vezes a dose terapêutica, não é considerada uma droga particularmente segura para ser usada isolada ${ }^{[99]}$.

\subsubsection{Associação Anestésica de Quetamina e Xilazina}

Segundo NICOLAU \& SPINOSA ${ }^{[93]}$, vários são os agentes administrados por via parenteral para obtenção de imobilização e/ou anestesia de aves. A quetamina e a xilazina estão entre os mais utilizados. A combinação desses agentes anestésicos promove bom relaxamento muscular e boa analgesia, pelo sinergismo entre eles, e produz hipnose segura ou anestesia em uma larga extensão de espécies. A respiração se torna ligeiramente deprimida, os olhos se encontram algumas vezes fechados, e o reflexo palpebral lento ou ausente. Em níveis mais profundos, observa-se flacidez do pescoço e asas. Os reflexos de deglutição e palpebral permanecem presentes, porém não há reflexo podal ${ }^{[91,94,95,99,100]}$.

Para muitas espécies de animais silvícolas, os efeitos da xilazina e quetamina são geralmente melhorados quando elas são administradas em combinação. Dessa forma, quando essas drogas são associadas a estimulação do SNC causada pela quetamina, e a bradicardia induzida pela xilazina, não parecem ser tão severas ou freqüentes ${ }^{[101]}$. A recuperação anestésica é mais rápida, suave, e menos conturbada do que com o uso apenas de quetamina. A indução anestésica também se apresenta mais suave, observando-se que, quando se utiliza a quetamina sozinha, estágios precoces da anestesia podem incluir rigidez, tremores, opistótomo, batimento das asas e ocasionalmente convulsões, porém, com a adição de xilazina, a ave apresenta fácil respiração e relaxamento corporal ${ }^{[94,95,96,100]}$.

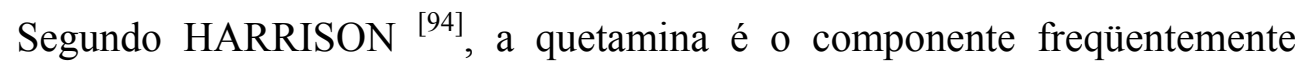
usado para anestesia parenteral em aves, nos Estados Unidos. Porém, devido ao efeito sinérgico produzido pela combinação dessa droga com tranqüilizantes, este autor, nunca utiliza a quetamina sozinha. Quando agentes parenterais são indicados, 
ele tem encontrado bons resultados usando a combinação de quetamina e xilazina. ROSSKOPF JR. \& WOERPEL ${ }^{[100]}$ também concordam que, se um anestésico injetável deve ser usado, esta é a combinação de escolha. Ela tem sido usada para a rotina cirúrgica de sexagem, e para certos procedimentos cirúrgicos que envolvem o bico e a face, em que o uso de anestesia inalatória é impossível.

Embora essa associação apresente várias vantagens, é preciso ter cautela quando administrada na espécie Aratinga solstitialis, que parece ser mais intolerante aos anestésicos do que outras espécies ${ }^{[100]}$.

Na Tabela 2 estão relacionadas as características da associação anestésica de quetamina e xilazina.

Tabela 2 - Características da associação quetamina/xilazina (10-30mg/kg quetamina) ${ }^{[94,95]}$.

\begin{tabular}{ll}
\hline \multicolumn{1}{c}{ Vantagens } & \multicolumn{1}{c}{ Desvantagens } \\
\hline Analgesia proporcionada & Prolongada recuperação com administração intramuscular \\
Rápida indução com administração intravenosa & Violenta recuperação em algumas aves \\
Rápida recuperação com administração intravenosa & Doses superiores (3x) induzem distúrbios respiratório e no ECG \\
Segura, até mesmo com repetidas doses & Hipotermia \\
Combinação parenteral preferida & Obito ocasional e inexplicado \\
Facilmente disponível & Diminuição de respiração e temperatura \\
Excelente para uso em campo & \\
\hline
\end{tabular}

Assim como neste experimento, trabalhos anteriores utilizaram esses anestésicos em aves, para estudos de TRMN. No estudo de VERHOYE et al. ${ }^{[85]}$, por exemplo, foi utilizada a associação de cloridrato de quetamina e cloridrato de xilazina para a obtenção de imagens de ressonância magnética do cérebro do canário (Serinus canaria) e do estorninho europeu (Sturnus vulgaris), e no estudo de BARTELS et al. ${ }^{[87]}$ foi utilizado o cloridrato de quetamina para a obtenção de imagens de ressonância magnética do acúmulo de tecido intracranial em patos domésticos (Anas platyrhynchos f. dom.).

\subsection{Doses da Associação Anestésica de Quetamina e Xilazina Recomendadas para Aves}

A mesma dose de um medicamento pode causar o efeito desejado em uma dada espécie animal, mas causar sérios prejuízos à saúde de outras. De fato, sabe-se que algumas espécies apresentam naturalmente deficiências ou ausências de enzimas 
responsáveis pela biotransformação de alguns medicamentos, dificultando sua eliminação do organismo ${ }^{[93]}$.

Assim, médicos veterinários enfrentam a necessidade de executar a contenção química e/ou anestesia nas espécies aviárias (mais de 850 espécies), dos mais diferentes tamanhos, comportamentos e hábitos alimentares, tornando-se impossível estabelecer uma dose aplicável do agente imobilizante para toda esta diversidade de aves. Acrescentam-se, ainda, diferenças de ordem anatômica, fisiológica e metabólica existentes entre as aves e os mamíferos, que não permitem a extrapolação de doses entre eles. Outro fator que se deve considerar é que pequenas aves se recuperam mais rapidamente que as maiores que tenham atingido o mesmo plano de anestesia, uma vez que as primeiras possuem maior taxa de metabolismo. Dessa forma, o resultado da anestesia em aves varia de uma espécie para outra, e o estado nutricional e particularidades de algumas espécies podem influenciar na resposta à anestesia ${ }^{[93]}$.

Outro fator importante relacionado à dose anestésica é a necessidade de pesagem dos animais para se calcular a dose exata a administrar, porque, independente do fármaco utilizado, uma vez aplicado na ave, não pode mais ser retirado. Freqüentemente, a dose anestésica para aves é tão pequena, que se faz necessário o uso de uma seringa dividida em microlitros para maior precisão ${ }^{[96]}$.

As doses da associação anestésica de quetamina e xilazina para aves, recomendadas por diferentes autores, estão relacionadas na Tabela 3.

Tabela 3 - Doses da associação anestésica de quetamina e xilazina para aves, recomendadas por diferentes autores.

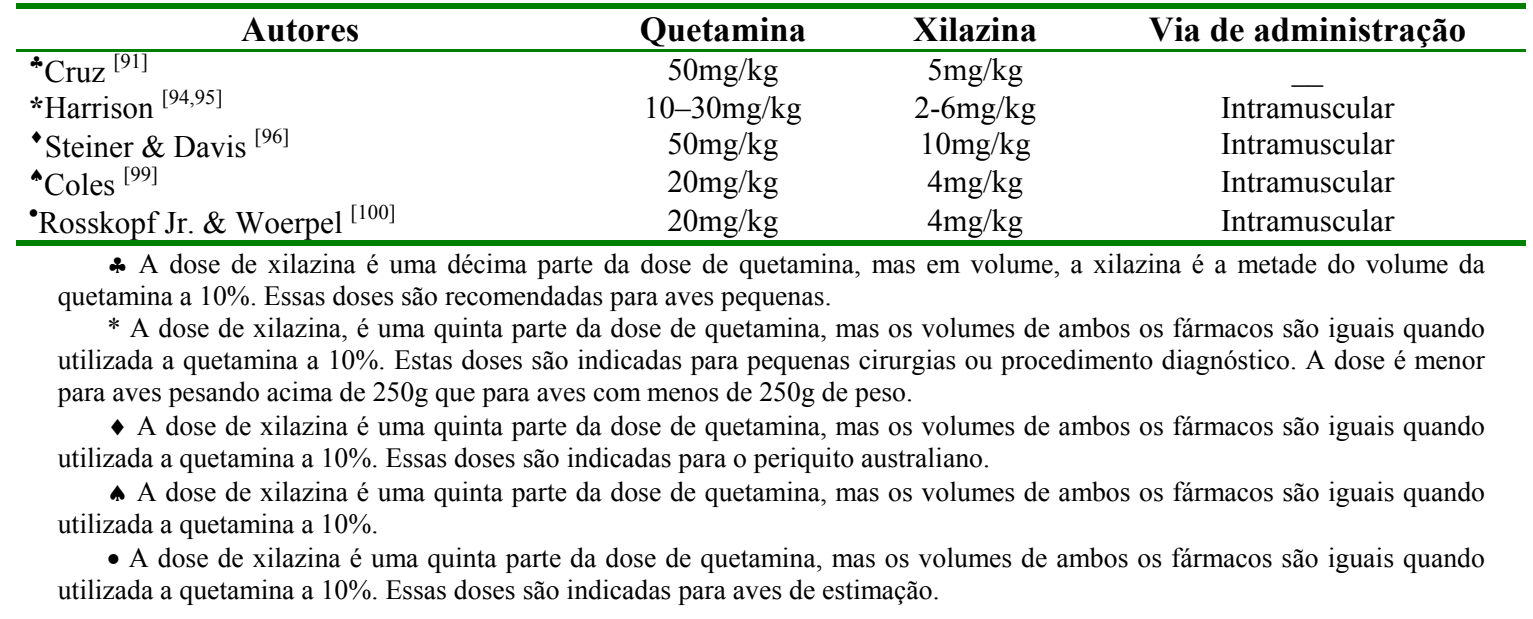


Como se pode observar, as doses de quetamina e xilazina indicadas para aves são altas, quando comparadas às usadas em cães e gatos: $15 \mathrm{mg} / \mathrm{kg}$ de quetamina e $1 \mathrm{mg} / \mathrm{kg}$ de xilazina para cães, e $10 \mathrm{mg} / \mathrm{kg}$ de quetamina e 0,5 a $0,8 \mathrm{mg} / \mathrm{kg}$ de xilazina para gatos, administradas por via intramuscular. Com esses dados supracitados, reforça-se a idéia de que as doses variam muito entre as espécies ${ }^{[102]}$.

\subsection{Cuidados Necessários Durante o Período de Recuperação Anestésica em Aves}

As aves são altamente susceptíveis à hipotermia, e a maioria dos anestésicos causa rápida queda da temperatura corpórea, devido à perda de calor pelo relaxamento muscular e/ou vasodilatação periférica. Esses efeitos se tornam ainda mais sérios em aves de pequeno porte, devido à rápida queda de temperatura em um curto espaço de tempo, podendo comprometer o controle do sistema respiratório e resultar em ausência de ventilação e morte. Portanto, durante a recuperação anestésica, é importante manter a ave aquecida para uma metabolização mais rápida $[90,91,93]$.

Quando se utiliza a associação de quetamina e xilazina, nesse período observa-se incoordenação, e algumas vezes um pouco de excitação. Assim, para evitar que o animal se machuque, recomenda-se enrolar frouxamente a ave em uma toalha de papel ou de pano, colocá-la em um "canudo" de papel, ou ainda enrolar uma camada de fita ao redor de suas asas, mantendo-as junto ao corpo, para impedir o batimento das asas. Também é importante a acomodação da ave em uma área escura, com supervisão fechada, almofadada, o que ajuda a prevenir o esmagamento periocular, que pode ocorrer devido a movimentos bruscos da cabeça. Dessa forma, evita-se que a ave tenha um despertar traumático ${ }^{[90,94,99,100]}$. 


\subsection{Aratinga leucophthalmus}

Pelo fato deste estudo ter utilizado animais da espécie Aratinga leucophthalmus, será feita a seguir uma breve descrição dessa ave.

Os psittaciformes estão distribuídos pela zona tropical do globo, de onde se irradiaram a áreas subtropicais e até frias, como a Patagônia. Poucas são as ordens tão características, sendo sua diagnose possível de imediato, embora variem extremamente de tamanho, oscilando o peso dos representantes brasileiros entre $25 \mathrm{~g}$ (tuim) e $1,5 \mathrm{~kg}$ (araras) ${ }^{[3]}$.

A maioria das espécies desta ordem é sexualmente monomórfica, dentre elas a Aratinga leucophthalmus (Müller, 1776), também conhecida como PeriquitãoMaracanã, Jandaia Maracanã, Aratinga-de-bando, Araguari, Maricatã, ou ainda White-eyed Conure, White-eyed Parakeet, entre outros (Figura 13). Essa espécie pode ser observada aos pares, em família ou em bandos de dez a trinta indivíduos, mede de 32 a $35 \mathrm{~cm}$ e pesa em torno de 100 a 218 gramas; sua cor é verde, com os lados da cabeça e pescoço com algumas penas vermelhas; apenas as pequenas coberteiras inferiores da asa são encarnadas, sendo as grandes inferiores amarelas, chamando muito a atenção em vôo; a região perioftálmica é nua e branca, a íris laranja, o bico cor-de-chifre clara. Vive na orla da mata, comum em muitos lugares. Ocorre das Guianas à Argentina, e em quase todo o Brasil. Alimenta-se de frutas, flores, sementes e até mesmo de insetos e suas larvas ${ }^{[3,103]}$. Segundo RUPLEY ${ }^{[12]}$, sua época de reprodução ocorre durante a primavera e o verão. Nidifica em buracos nas árvores, às vezes em grutas calcárias (Mato Grosso) e em paredões rochosos. $\mathrm{Na}$ região cárstica de Minas Gerais, reproduz-se regularmente em buracos da rocha erodida e às vezes, em barrancos ${ }^{[3]}$. O número de ovos varia de 3 a 4 , e em cativeiro, o período de incubação é de 4 semanas. Segundo COLLAR ${ }^{[103]}$, essa espécie não é considerada globalmente ameaçada. 


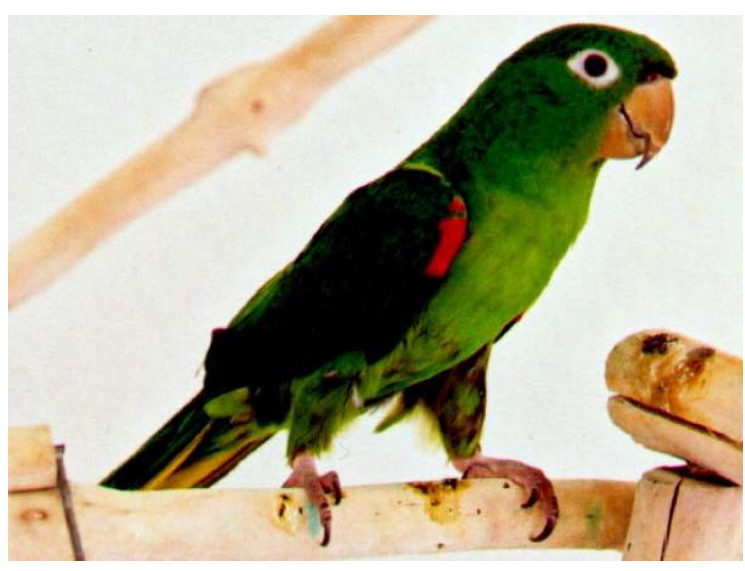

REINO Animalia

FILO Chordata

Classe Aves

ORDEM Psittaciformes

FAMÍLIA Psittacidae

GÊNERO Aratinga

ESPÉCIE Aratinga leucophthalmus

Figura 13 - Periquitão-maracanã (Aratinga leucophthalmus) ${ }^{[104,105,106]}$. 


\section{Materiais e Método}

\subsection{Pré-Experimento}

Realizou-se, em uma primeira etapa deste trabalho, um estudo preliminar a partir do qual foi possível determinar um protocolo de exame, que serviu como guia a ser seguido no experimento definitivo. Este estudo preliminar também foi importante para se estabelecerem critérios quanto a anestesia, aquisição de imagens, posicionamento dos animais dentro do tomógrafo e escolha de uma única espécie de ave a ser utilizada no experimento final, para tornar a amostra de estudo mais homogênea.

\subsubsection{Tomógrafo}

Foi utilizado um tomógrafo Varian, modelo Inova, com um campo magnético de $2 \mathrm{~T}$, que opera na freqüência de $85 \mathrm{MHz}$ para núcleos de hidrogênio $\left({ }^{1} \mathrm{H}\right)$, e pertence à Embrapa Instrumentação Agropecuária de São Carlos.

\subsubsection{Animais}

Foram utilizados vinte animais, provenientes do Centro de Triagem de Animais Silvestres de São Carlos, relacionados na Tabela 4. 
Tabela 4 - Animais utilizados no pré-experimento.

\begin{tabular}{ccc}
\hline $\begin{array}{c}\text { Espécie } \\
\text { (nome científico) }\end{array}$ & $\begin{array}{c}\text { Espécie } \\
\text { (nome comum) }\end{array}$ & $\mathbf{N}^{\circ}$ aves \\
\hline Ara ararauna & Arara Canindé & 4 \\
Aratinga leucophthalmus & Periquitão-maracanã & 3 \\
Brotogeris chiriri & Periquito-de-encontro-amarelo & 2 \\
Gallinula chloropus & Frango d'água & 1 \\
Amazona aestiva & Papagaio verdadeiro & 2 \\
Pionus maximiliani & Maitaca-de-Maximiliano & 1 \\
Columbina talpacoti & Rolinha-roxa & 1 \\
Cariama cristata & Siriema & 1 \\
Ramphastos toco albogularis & Tucanuçu & 5 \\
\hline
\end{tabular}

\subsubsection{Critérios Estabelecidos}

\subsubsection{Imagens Tomográficas}

Em ensaios tomográficos preliminares, verificou-se que era possível por meio de imagens coronais, a visualização dos órgãos internos das aves em estudo, desde os maiores aos menores exemplares (Figura 14).

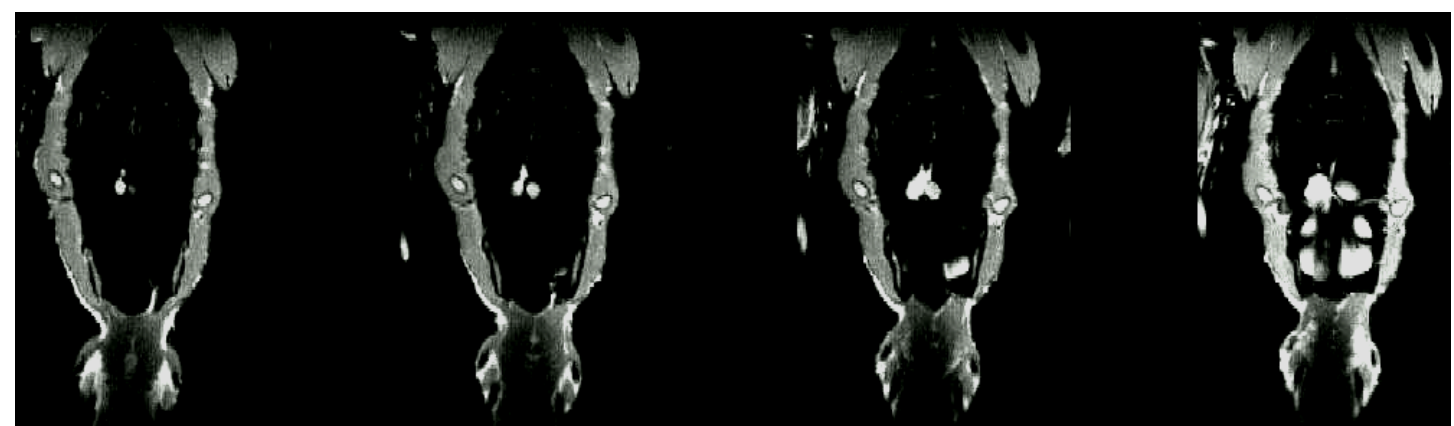

a)

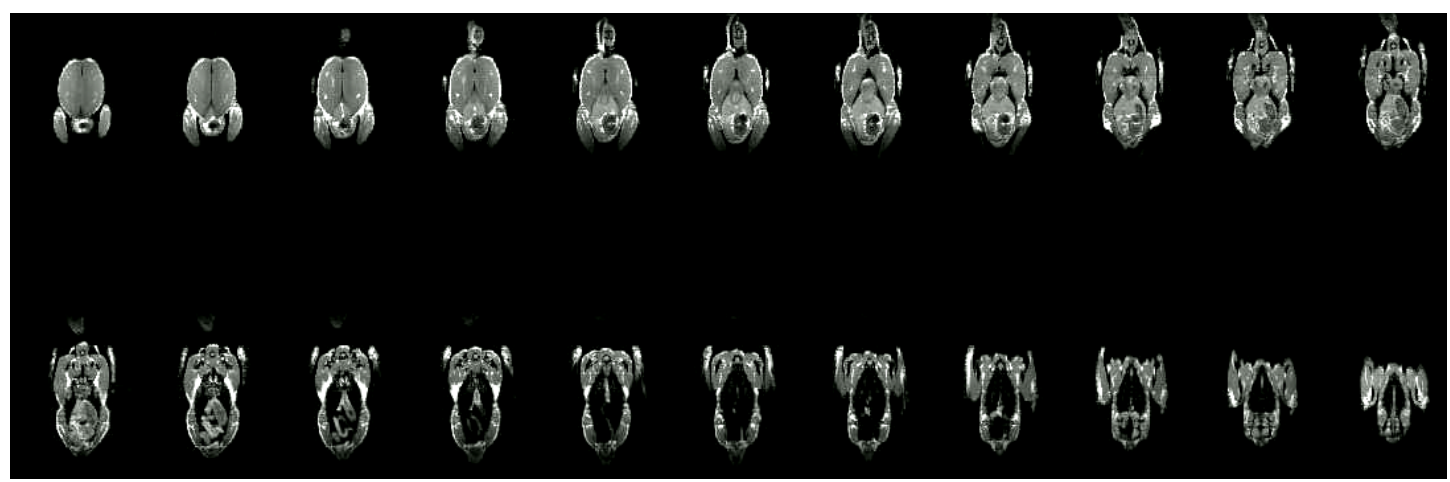

b)

Figura 14 - a) Seqüência parcial de imagens tomográficas de Arara Canindé (Ara ararauna) (plano coronal). Campo de visão: $11 \mathrm{~cm} \times 24 \mathrm{~cm}$; b) Seqüência total de imagens tomográficas de Papagaio verdadeiro (Amazona aestiva) (plano coronal). Campo de visão: $13 \mathrm{~cm} \times 24 \mathrm{~cm}$. 


\subsubsection{Identificação dos Lados Esquerdo e Direito da Imagem}

Neste estudo tomográfico inicial, encontrou-se grande dificuldade em identificar os lados direito e esquerdo do animal na imagem. Para isso, foram confeccionados pequenos tubos contendo óleo em seu interior, ficando estabelecido que estes seriam sempre colocados sob a asa esquerda de cada animal.

\subsubsection{Ajustes do Equipamento x Qualidade de Imagem}

Inicialmente, observou-se que a qualidade de algumas imagens era muito boa, mas o seu tempo de aquisição era muito longo (em média 25 minutos). Outros ensaios demonstravam rápida aquisição, porém com pobre qualidade. Precisava-se, dessa forma, ajustar os parâmetros de aquisição das imagens, de modo a adquiri-las com boa qualidade, em menor tempo possível, aproveitando-se o período hábil anestésico do animal.

Após a análise de muitas imagens e seus respectivos tempos de aquisição, optou-se por utilizar, no experimento final, parâmetros que forneceram uma imagem de qualidade, adquirida com tempo de oito minutos e trinta e oito segundos. Os valores então estabelecidos, foram de 1,0s para TR, 0,0137s para TE, espessura de corte de 2,0mm, matriz de 512 x 128 pixéis, campo de visão com lro e lpe de $14 \mathrm{~cm}$ e $7 \mathrm{~cm}$, respectivamente, e número de slices (fatias) 13, caracterizando-se, dessa forma, uma imagem ponderada por densidade de prótons.

\subsubsection{Determinação do Posicionamento da Ave Dentro do Tomógrafo}

Quanto ao posicionamento da ave na bandeja, ficou estabelecido o decúbito ventral, pois durante este estudo inicial, observou-se que os rins e as gônadas, eram melhor visualizados nesse decúbito. Além disso, sabe-se que a anestesia deprime a ventilação em aves, e a posição do animal pode afetá-la significantemente. Já no ano de 1896, foi reconhecido que a ventilação era reduzida em aves posicionadas em decúbito dorsal. Um fator que pode contribuir para este fenômeno é o peso das 
vísceras sobre os sacos aéreos abdominais, reduzindo seu volume efetivo e levando a uma depressão respiratória ${ }^{[91,107]}$.

Também foi estabelecido, apenas para padronização, que todas as aves seriam colocadas dentro do tomógrafo, de forma a que a sua extremidade cranial ficasse voltada para a parte posterior do equipamento.

\subsubsection{Escolha dos Anestésicos}

Neste experimento, o uso da contenção farmacológica foi extremamente necessário para que os animais permanecessem imóveis durante todo o tempo de aquisição das imagens, porque durante esse período, qualquer movimento prejudicaria a qualidade da imagem, tornando-a borrada e, portanto, sem nitidez de detalhes. Desta forma, optou-se pelo uso da associação anestésica de cloridrato de quetamina e cloridrato de xilazina, devido a vários fatores:

- Inviabilidade da utilização de anestesia inalatória, pela presença de componentes ferromagnéticos na estrutura do aparelho de anestesia;

- Constitui uma opção anestésica recomendada por vários autores e utilizada por diversos profissionais da área de animais silvestres;

- Esses anestésicos já foram utilizados em aves, para outros estudos de TRMN $[85,87]$.

\subsubsection{Determinação da Dose Anestésica}

Foi observado que, ao se utilizar uma dose de $43,8 \mathrm{mg} / \mathrm{kg}$ de cloridrato de quetamina e $4,4 \mathrm{mg} / \mathrm{kg}$ de cloridrato de xilazina em uma ave da espécie Aratinga leucophthalmus, obteve-se um tempo hábil anestésico muito curto em relação àquele desejado. Com a administração de doses anestésicas de $52,8 \mathrm{mg} / \mathrm{kg}$ de cloridrato de quetamina e 5,3mg/kg de cloridrato de xilazina, em uma ave da espécie Pionus maximiliani (da mesma família da espécie Aratinga leucophthalmus), obteve-se um tempo hábil anestésico viável à realização do exame tomográfico.

A partir desses resultados, baseando-se nas doses recomendadas por diversos autores e naquelas comumente utilizadas por profissionais da área de 
animais silvestres, tentou-se ponderar uma dose que atendesse às necessidades do trabalho e ao mesmo tempo fosse segura para o animal. Dessa forma, foram estabelecidas as doses de $53,3 \mathrm{mg} / \mathrm{kg}$ de cloridrato de quetamina e $4,7 \mathrm{mg} / \mathrm{kg}$ de cloridrato de xilazina (seguindo praticamente o que sugere CRUZ) ${ }^{[91]}$.

Cabe ressaltar que, neste estudo inicial a resposta anestésica variou muito entre as espécies, inclusive entre animais da mesma espécie.

\subsubsection{Escolha da Espécie de Ave}

A Aratinga leucophthalmus foi a espécie escolhida, devido a vários fatores:

- Pertence à família Psittacidae. Esta é a família que apresenta o maior número de espécies ameaçadas de extinção no Brasil, sendo a maioria dos seus exemplares monomórfica, dificultando sua reprodução em cativeiro;

- Constitui um psitacídeo de porte médio (nem tão grande como uma arara, nem tão pequeno como um periquito), podendo-se extrapolar os resultados deste estudo às outras espécies de psitacídeos, de porte um pouco menor ou maior;

- Espécie abundante na região de São Carlos (São Paulo), possibilitando a obtenção de maior quantidade de indivíduos para o estudo (comunicação pessoal com a equipe do CETAS - Centro de Triagem de Animais Silvestres de São Carlos);

- Animal de melhor contenção e manipulação, quando comparado às araras, aos tucanos e aos papagaios (observações realizadas durante este estudo inicial).

\subsubsection{Desenvolvimento de Protocolo de Exame}

Este estudo inicial foi de extrema importância para o estabelecimento de um protocolo de exame a ser seguido no experimento definitivo, e para se padronizar cada etapa desse protocolo. 


\subsection{Experimento Definitivo}

A parte experimental deste trabalho foi aprovada, em protocolo sob o número 105/2001, pela Comissão de Ética em Experimentação Animal (CEEA) do Instituto de Ciências Biomédicas da Universidade de São Paulo (ICB/USP), estando de acordo com os princípios éticos adotados pelo Colégio Brasileiro de Experimentação Animal (COBEA) (Anexo 1). Os animais foram transportados mediante licença do IBAMA, processo número 02027. 008093/01-93 (Anexo 2).

\subsubsection{Animais}

Este estudo contou com dez aves da ordem Psittaciformes, espécie Aratinga leucophthalmus, provenientes do CETAS de São Carlos, que se constitui em um centro de triagem de animais silvestres apreendidos pela Polícia Florestal local.

O número total de aves da espécie Aratinga leucophthalmus utilizadas neste experimento dependeu do número de animais disponíveis nesse centro de triagem.

\subsubsection{Anestésicos}

Os anestésicos utilizados neste estudo foram o cloridrato de quetamina $10 \%$ (Francotar ${ }^{\circledR}, \mathrm{n}^{\mathrm{o}}$ de partida 004/00, fabricado pela Virbac do Brasil) e o cloridrato de xilazina $2 \%$ (Rompun $^{\circledR}, \mathrm{n}^{\mathrm{o}}$ de partida $004 / 00$, fabricado pela Bayer), sendo utilizada a mesma partida dos anestésicos em todos os animais do experimento definitivo (Figura 15). 


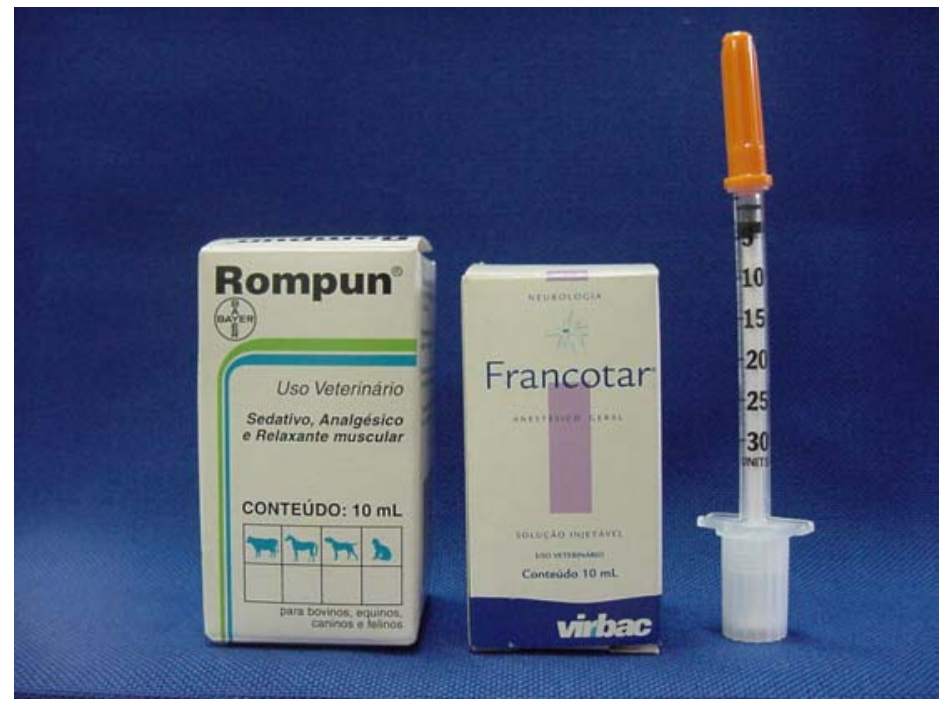

Figura 15 - Anestésicos utilizados no experimento.

\subsubsection{Tomógrafo}

Para a realização deste trabalho, foi utilizado um tomógrafo Varian, modelo Inova, com um campo magnético de $2 \mathrm{~T}$, que opera na freqüência de $85 \mathrm{MHz}$ para núcleos de hidrogênio $\left({ }^{1} \mathrm{H}\right)$, e pertence à Embrapa Instrumentação Agropecuária de São Carlos (Figura 16).

Também foi utilizada uma bobina do tipo gaiola, com $8 \mathrm{~cm}$ de diâmetro interno e $20 \mathrm{~cm}$ de comprimento.

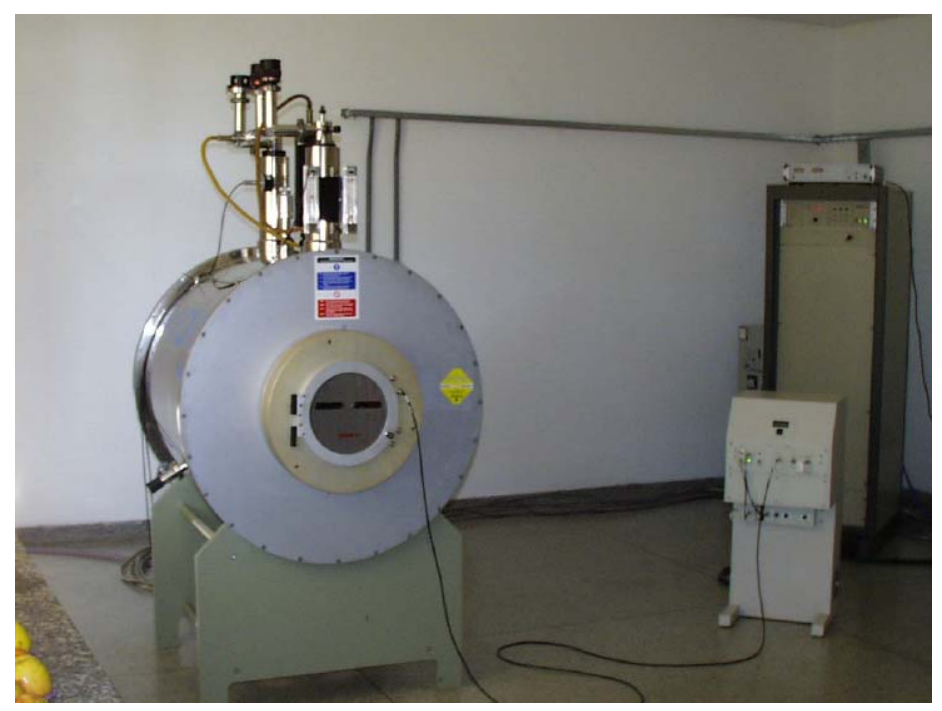

Figura 16 - Tomógrafo de ressonância magnética nuclear da Embrapa Instrumentação Agropecuária. 


\subsubsection{Protocolo de Exame}

Foi estabelecido um protocolo para a realização deste experimento, constituído de três etapas:

1. Preparação da ave para o exame tomográfico;

2. Exame tomográfico propriamente dito;

3. Procedimento pós-exame tomográfico.

Na seqüência serão descritas todas as etapas do procedimento experimental, as quais foram realizadas da mesma forma com todos os animais do estudo, tendo-se em vista o cuidado de proporcionar o menor estresse possível aos mesmos.

\subsubsection{Preparação da Ave para o Exame Tomográfico}

\subsection{Transporte}

Os animais foram transportados do CETAS de São Carlos pela manhã, a fim de aproveitar o jejum da madrugada, em grupos de dois ou três, para o prédio da Embrapa Instrumentação Agropecuária de São Carlos, onde está localizado o tomógrafo.

Ao final de cada dia, os animais foram levados de volta ao seu local de origem.

\subsection{Contenção Física}

Nas instalações da Embrapa Instrumentação Agropecuária, cada animal foi contido, utilizando-se luvas de couro para a proteção das mãos contra possíveis bicadas e arranhões (Figura 17). 


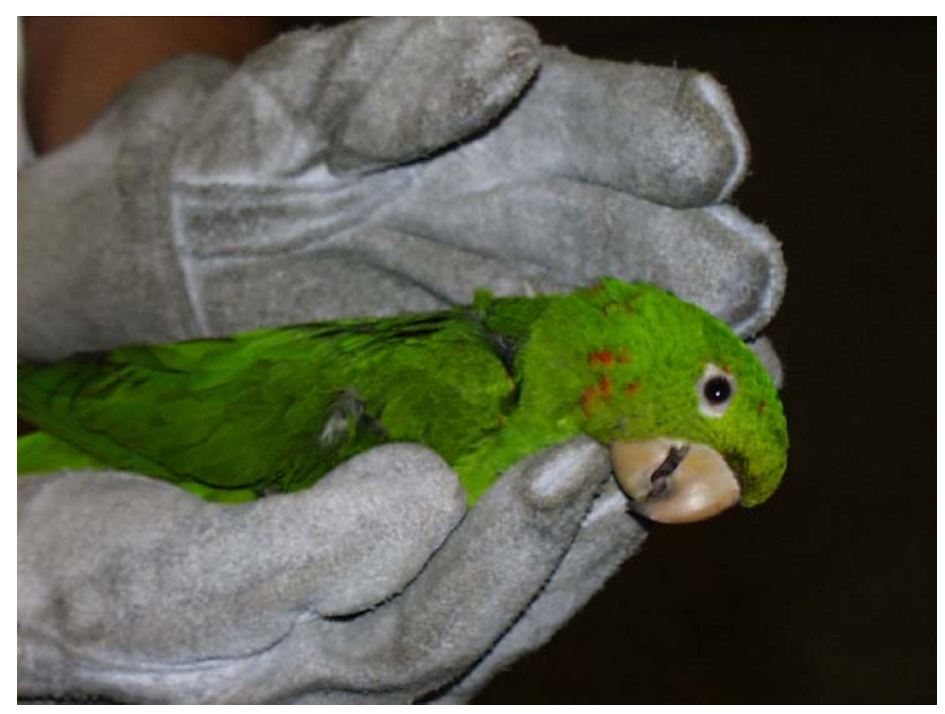

Figura 17 - Contenção física do periquitão-maracanã (Aratinga leucophthalmus).

\subsection{Pesagem}

Uma vez contida, a ave foi colocada em uma caixa de $26 \mathrm{~cm} \times 26 \mathrm{~cm}$ e peso aproximado de 129,5 gramas, devidamente ventilada, e então pesada em uma balança eletrônica da marca Marte, com capacidade mínima de 0,5 gramas e máxima de 2000 gramas (Figura 18).

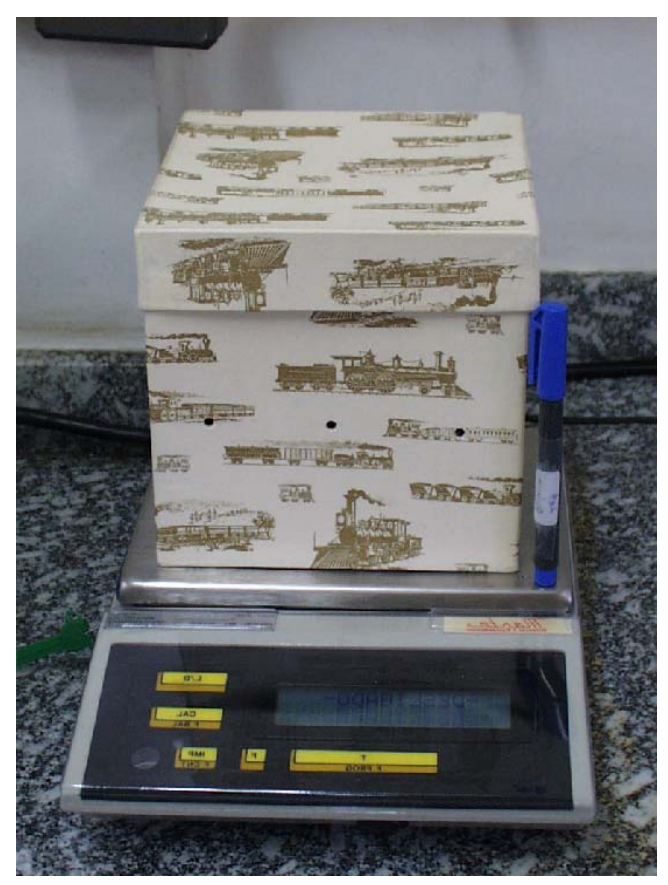

Figura 18 - Caixa e balança utilizadas para a pesagem dos animais. 


\subsection{Procedimento Anestésico}

As doses anestésicas utilizadas neste estudo foram de $53,3 \mathrm{mg} / \mathrm{kg}$ de cloridrato de quetamina e $4,7 \mathrm{mg} / \mathrm{kg}$ de cloridrato de xilazina, as quais foram estabelecidas a partir do pré-experimento. Uma vez conhecido o peso de cada animal, calculou-se a dose de anestésico a ser administrada. Os anestésicos foram colocados em uma mesma seringa, como sugerem HARRISON ${ }^{[94,95]}$ e MASSONE ${ }^{[102]}$. A via de administração foi a intramuscular, no músculo peitoral. Foi utilizada seringa de insulina para doses de 30 unidades $(0,3 \mathrm{cc})$, com agulha curta $(8,0 \mathrm{~mm} \mathrm{x}$ $0,3 \mathrm{~mm}$ ), devido ao pequeno tamanho dos animais e para maior precisão das doses (doses muito pequenas).

\subsubsection{Exame Tomográfico}

\subsection{Posicionamento da Ave}

Uma vez esperado o período de latência do anestésico, a ave foi colocada na bandeja do tomógrafo, em decúbito ventral, conforme estabelecido no préexperimento.

Sob a asa esquerda da ave foi posicionado um pequeno tubo medindo aproximadamente $2,7 \mathrm{~cm}$ de comprimento por $3 \mathrm{~mm}$ de largura e contendo óleo em seu interior, para identificar o lado esquerdo do animal na imagem, uma vez que o ovário, na fềmea, está localizado desse mesmo lado (Figuras 19 e 20). 


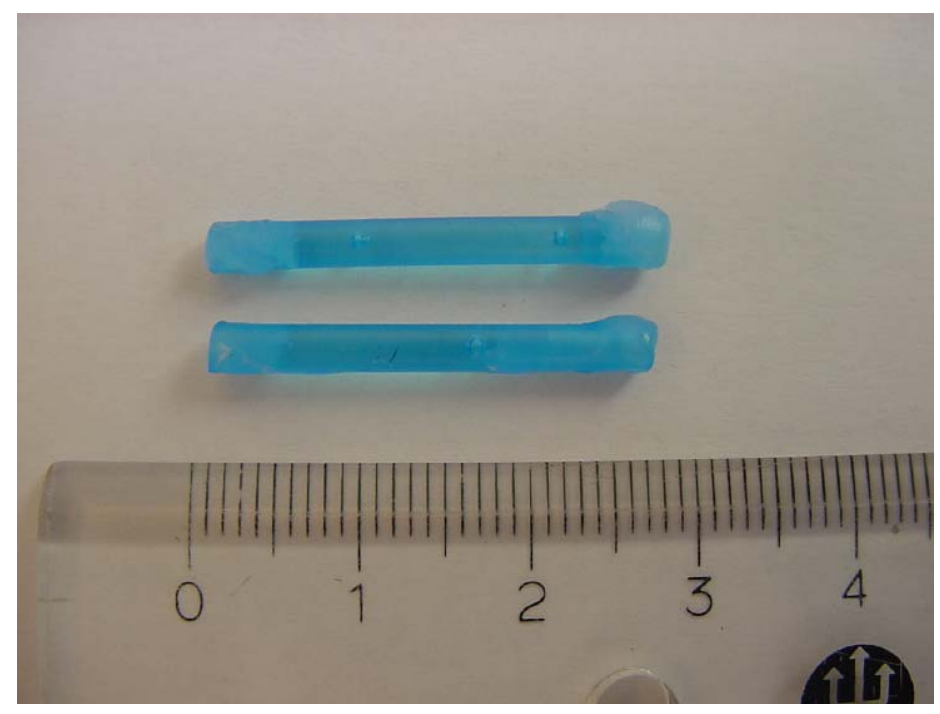

Figura 19 - Tubos contendo óleo em seu interior.

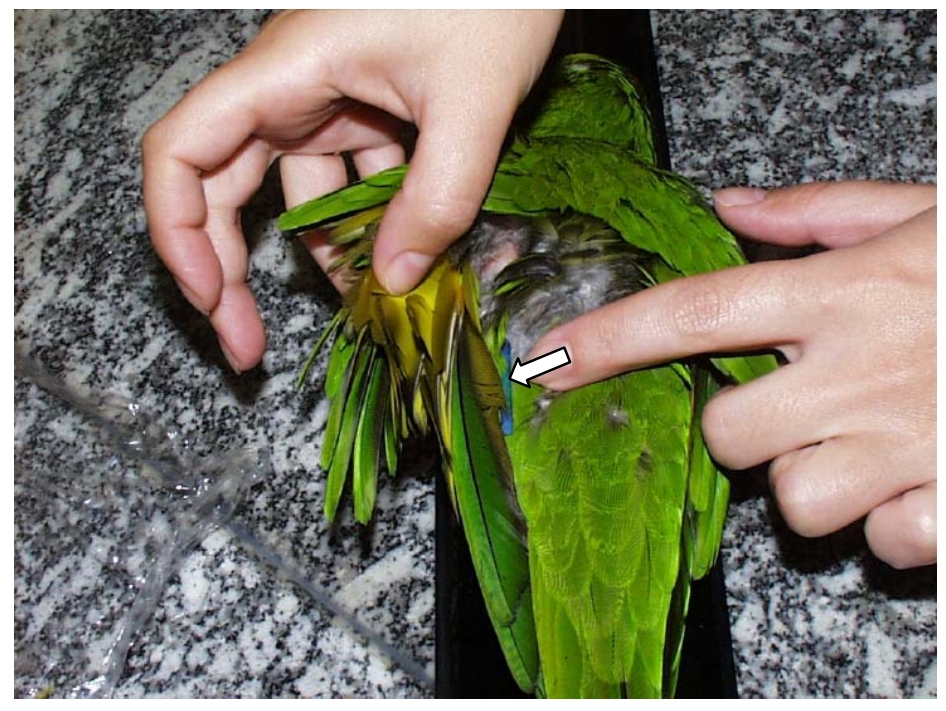

Figura 20 - Tubo contendo óleo colocado sob a asa esquerda do periquitão-maracanã (Aratinga leucophthalmus) (seta branca).

O animal, então, foi envolto por um filme plástico de PVC, a fim de permanecer imóvel durante a aquisição das imagens, e para que se sentisse contido, e assim, caso se recuperasse da anestesia antes do término do exame, não tentasse sair, podendo se machucar ou mesmo danificar o equipamento (Figura 21). 


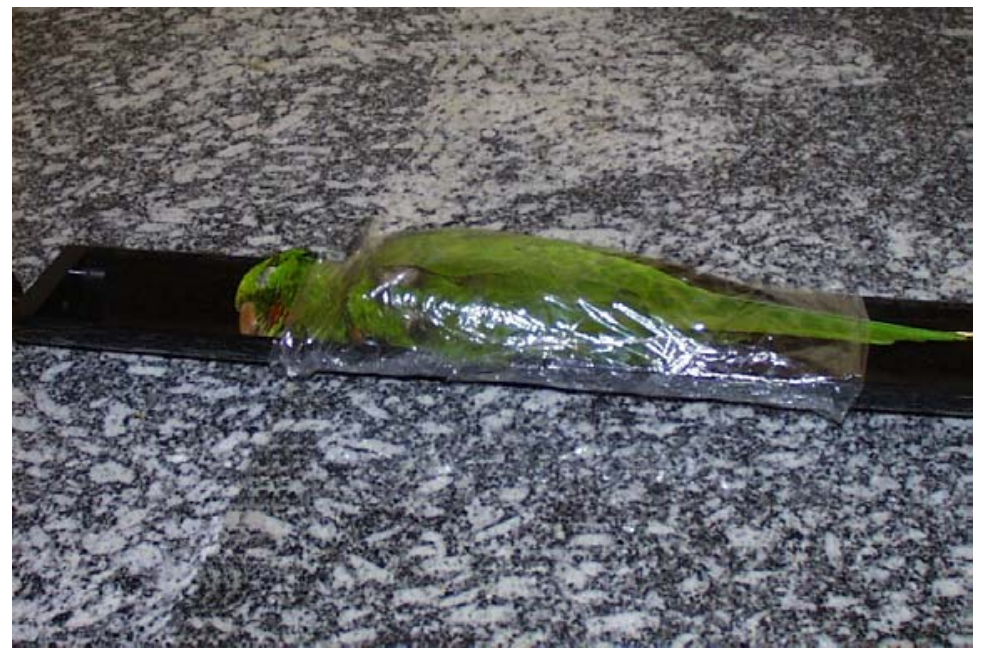

Figura 21 - Periquitão-maracanã (Aratinga leucophthalmus) dentro da bandeja e envolto pelo filme plástico.

Uma vez a ave dentro da bandeja, foi então colocada na bobina de detecção, própria do tomógrafo (Figura 22).

A bandeja e a bobina de detecção foram, a seguir, colocadas e centralizadas dentro do aparelho de tomografia, de forma a que a extremidade cranial do animal ficasse voltada para a parte posterior do tomógrafo (Figura 22).

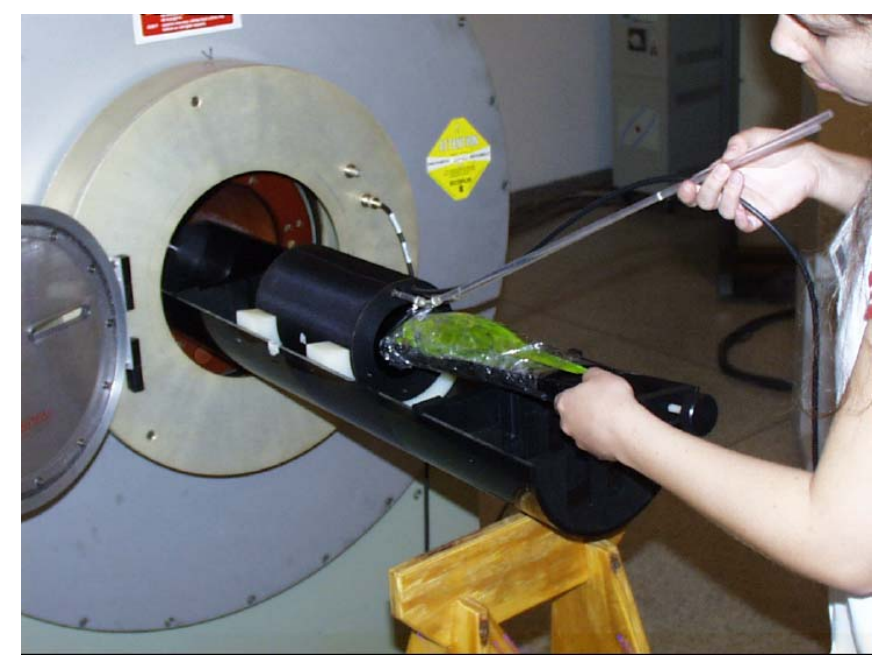

Figura 22 - Posicionamento do periquitão-maracanã (Aratinga leucophthalmus) dentro do tomógrafo. 


\subsection{Ajustes do Equipamento}

Após o posicionamento da ave no tomógrafo, este foi fechado, e em seguida foi realizada a sintonização da bobina de detecção (Figura 23).

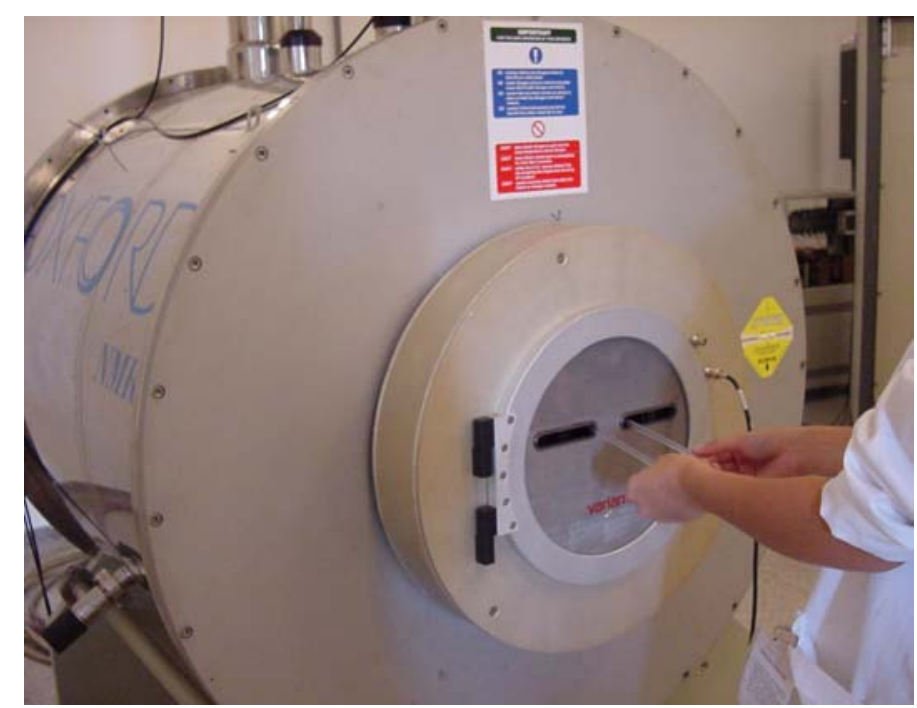

Figura 23 - Sintonização da bobina de detecção.

$\mathrm{Na}$ estação, foram ajustados os parâmetros de aquisição das imagens, de maneira a padronizar os mesmos parâmetros para todos os animais. Foram utilizados valores de 1,0s para TR, 0,0137s para TE, espessura de corte de 2,0mm, matriz de 512 x 128 pixéis, campo de visão com lro e lpe de $14 \mathrm{~cm}$ e $7 \mathrm{~cm}$, respectivamente, e número de slices (fatias) 13. Esses valores utilizados caracterizaram uma imagem ponderada por densidade de prótons. 


\subsection{Aquisição das Imagens}

Em seguida, foram adquiridas as imagens nos planos sagital e coronal respectivamente (Figuras 24a e 24b).

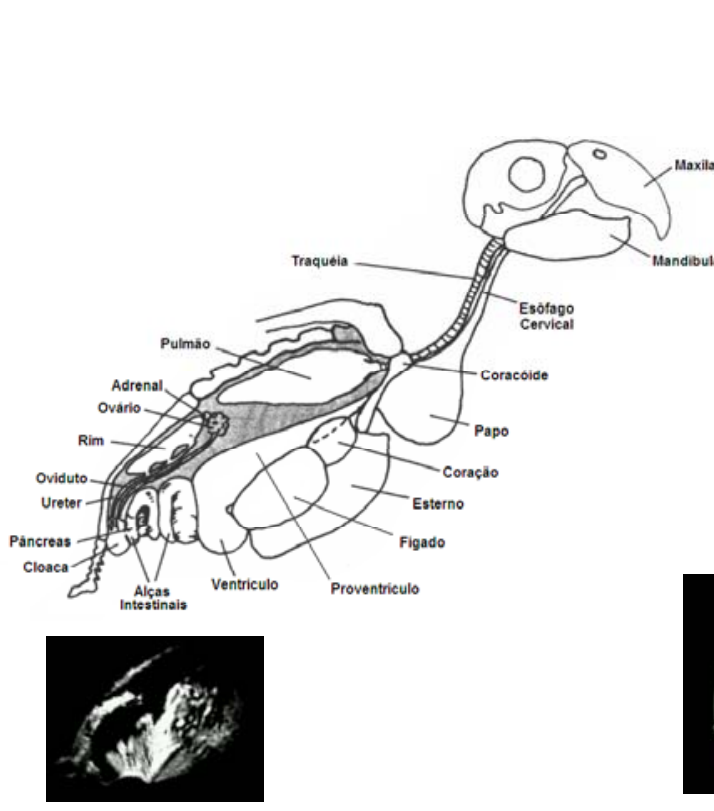

a)

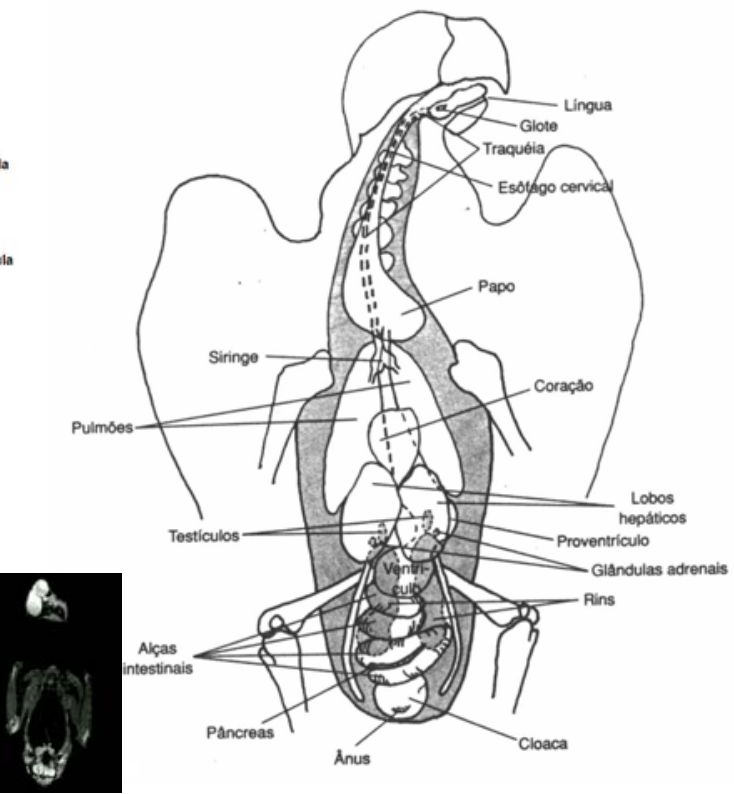

b)

Figura 24 - a) Representação esquemática da secção do corpo de um psitacídeo no plano sagital; b) Representação esquemática da secção do corpo de um psitacídeo no plano coronal ${ }^{[108]}$.

Inicialmente, foi adquirida uma imagem no plano sagital, e a partir dela, determinaram-se as linhas de cortes tomográficos que corresponderiam às seqüências de imagens no plano coronal (Figura 25a). As imagens coronais foram adquiridas em três diferentes inclinações dessas linhas de cortes tomográficos pré-marcadas no plano sagital (Figuras 25b, 25c e 25d).

O órgão usado como referência para o posicionamento das linhas de cortes tomográficos no plano sagital foi o rim, porque, a partir do conhecimento anatômico, sabe-se que as gônadas se relacionam topograficamente com esse órgão (Figuras 2 e 4), e, além disso, ele é muito bem visualizado nas imagens tomográficas (Figura 25a). 


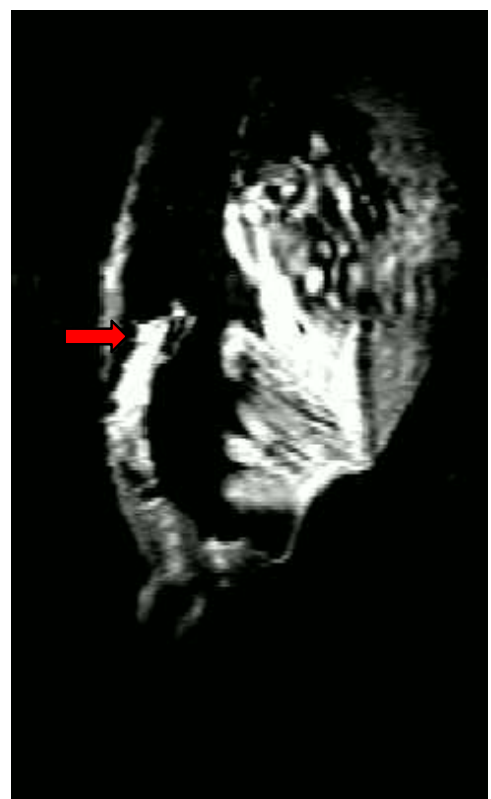

a)

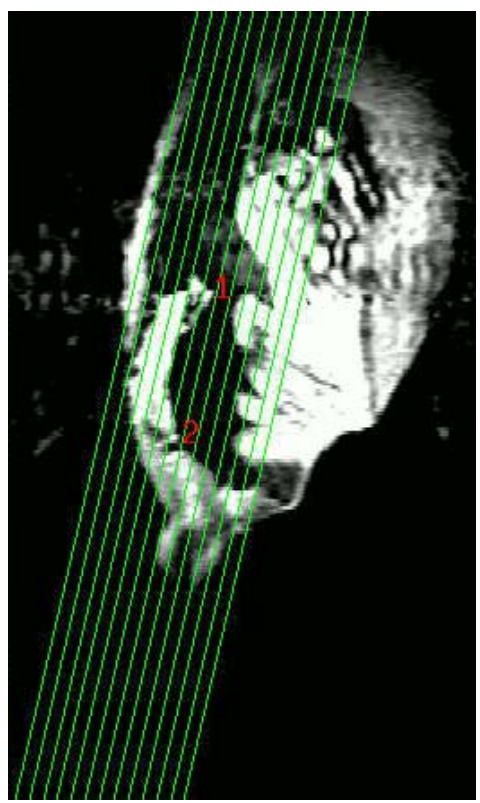

c)

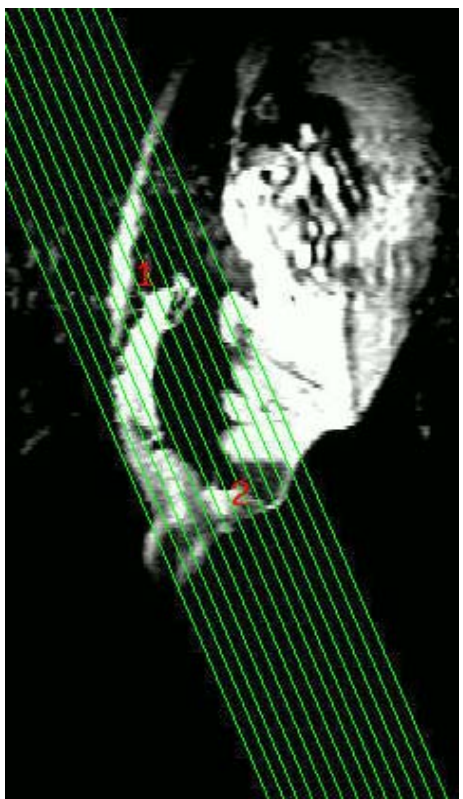

b)

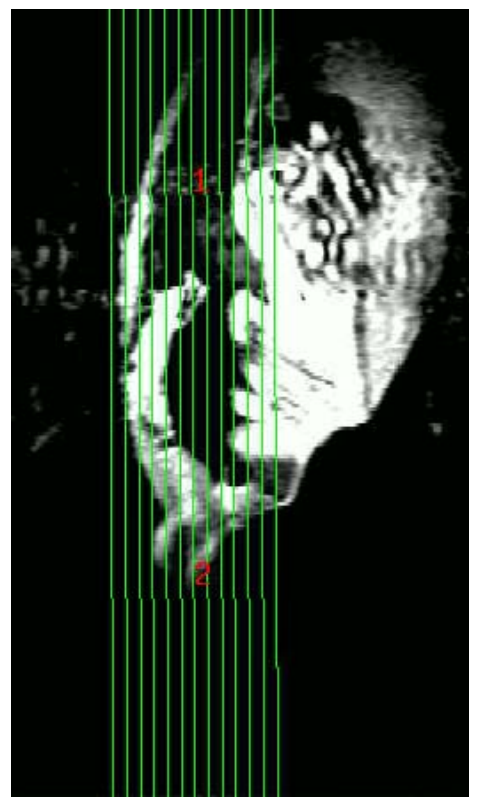

d)

Figura 25 - a) Imagem tomográfica do periquitão-maracanã (Aratinga leucophthalmus) no plano sagital, em que o rim corresponde à seta vermelha; b) c) d) Imagens tomográficas no plano sagital, demonstrando as três diferentes inclinações das linhas de cortes tomográficos utilizadas para a aquisição das imagens coronais. Campo de visão: $7 \mathrm{~cm} \times 14 \mathrm{~cm}$. 
Adquiridas as imagens coronais, estas foram salvas e armazenadas no computador, para posterior estudo e interpretação (Figura 26).

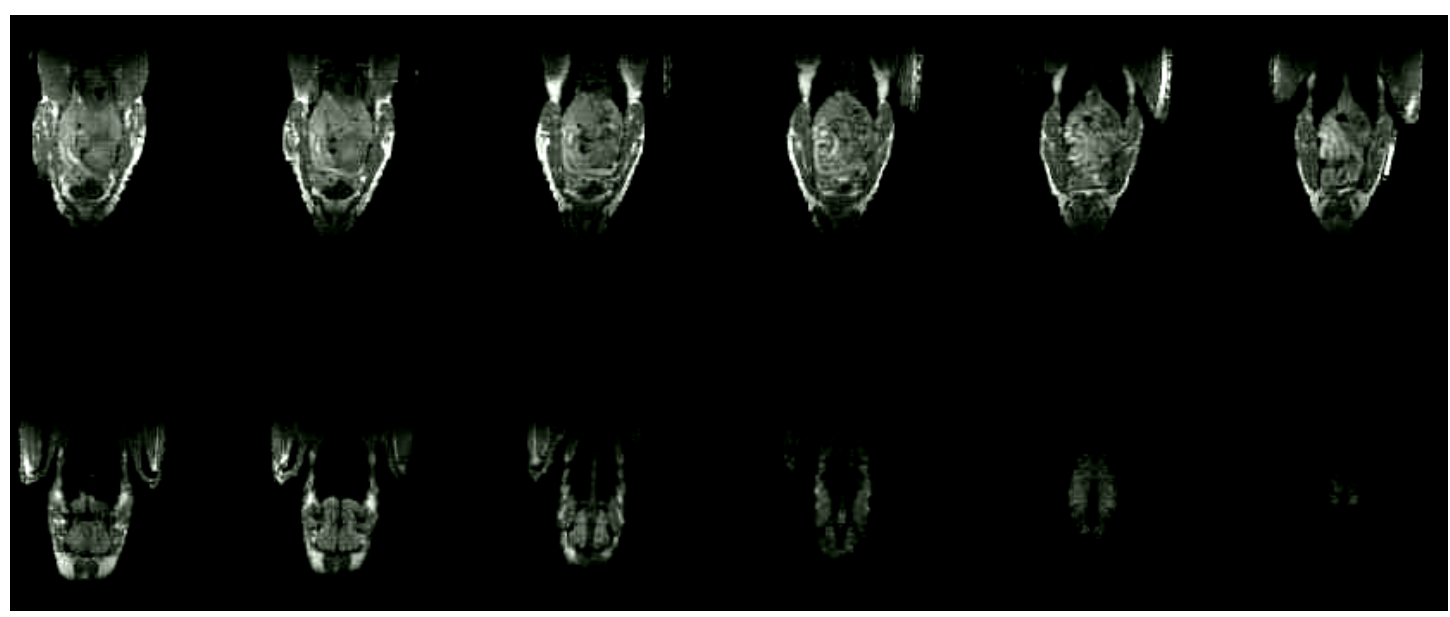

Figura 26 - Seqüência de imagens tomográficas do periquitão-maracanã (Aratinga leucophthalmus) no plano coronal. Campo de visão: $7 \mathrm{~cm} \times 14 \mathrm{~cm}$.

\subsubsection{Procedimento Pós-Exame Tomográfico}

\subsection{Colocação das Anilhas}

Uma vez encerrado o exame, a ave foi retirada do tomógrafo e da bandeja, e identificada mediante a colocação de uma anilha de alumínio, confeccionada na oficina da Embrapa Instrumentação Agropecuária, com diâmetro interno de 8mm, contendo um número de identificação gravado, que variava de 1 a 10 (Figuras 27 e 28). O mesmo número da anilha correspondia ao número das imagens desse animal, e posteriormente ao número de sua amostra de sangue. 


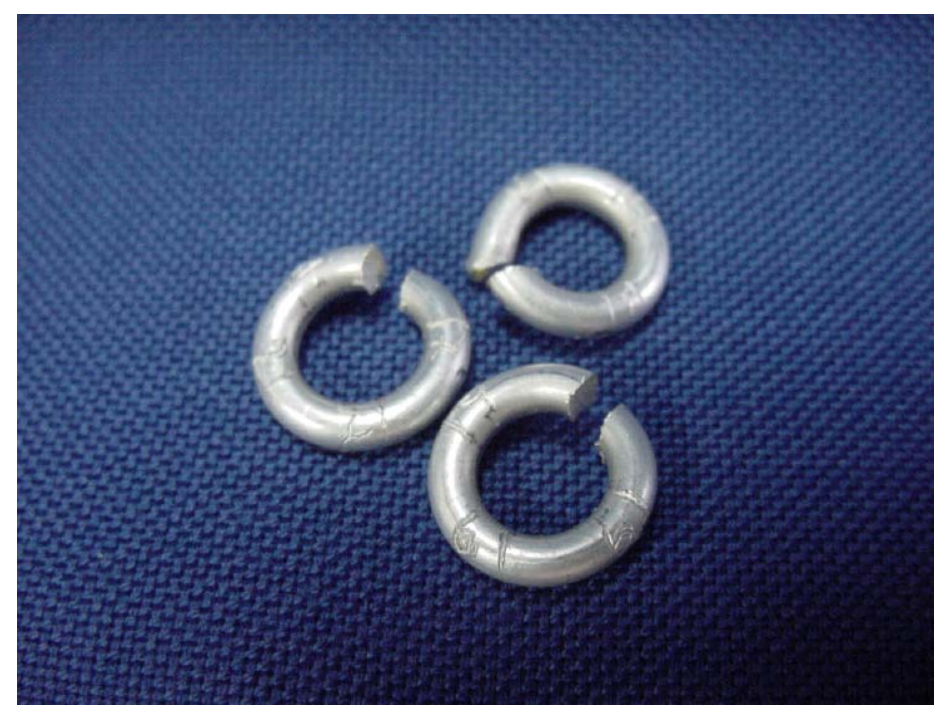

Figura 27 - Anilhas utilizadas para identificação das aves.

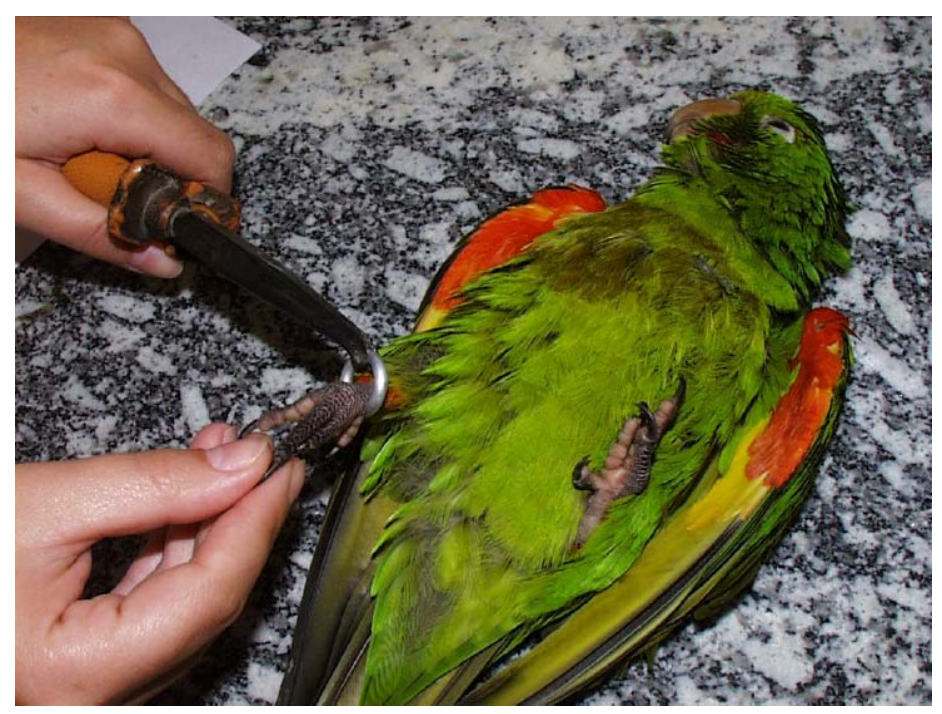

Figura 28 - Colocação da anilha.

\subsection{Recuperação Anestésica}

Após a colocação da anilha, a ave foi enrolada em uma folha de jornal, para se manter mais aquecida, evitando a dissipação de calor corpóreo, e assim amenizando a hipotermia provocada pela anestesia. Além disso, tal procedimento também foi realizado a fim de limitar os movimentos da ave, e assim, impedir que ela se debatesse e se machucasse (Figura 29). 


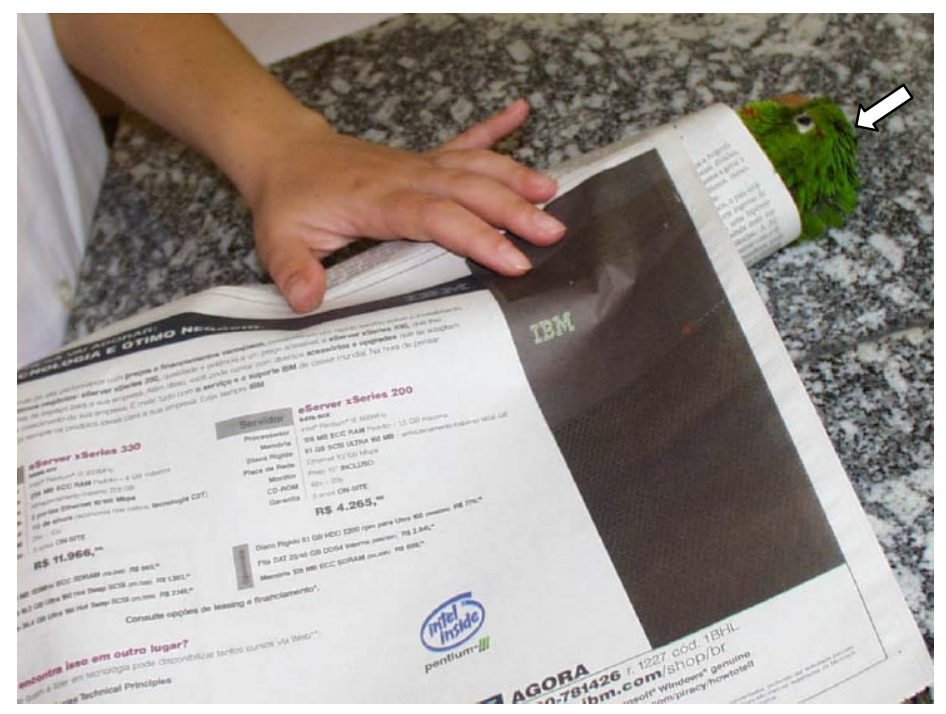

Figura 29 - Periquitão-maracanã (Aratinga leucophthalmus) sendo envolto pelo jornal.

As aves foram, então, colocadas em suas caixas de contenção, devidamente forradas com cama, em um ambiente escuro, silencioso e sem o trânsito de pessoas, para que houvesse recuperação anestésica mais tranqüila.

\subsubsection{Exame de Polimorfismo de DNA}

Foi realizado o exame de polimorfismo de DNA em todas as aves do experimento final, por se tratar de um método de sexagem com quase $100 \%$ de eficiência ${ }^{[109]}$. O objetivo da realização desse exame foi comparar os seus resultados àqueles adquiridos da interpretação das imagens tomográficas, a fim de comprovar a eficiência do método de sexagem com uso da TRMN. A descrição do exame de polimorfismo de DNA se encontra no Anexo 3.

\subsubsection{Análise Estatística}

Foi realizada uma análise estatística descritiva, incluindo média, desviopadrão, erro-padrão da média, valor máximo e valor mínimo dos parâmetros quantitativos peso animal, dose anestésica, período hábil anestésico, período de latência e tempo de duração do exame. 


\section{Resultados}

\subsection{Avaliação dos Anestésicos Utilizados}

\subsubsection{Clínica}

A avaliação clínica constou do acompanhamento de todos os animais durante a indução, período hábil e período de recuperação anestésica, tendo-se observado o seu comportamento diante dos anestésicos administrados.

Dessa forma, no período de recuperação anestésica, observou-se uma certa agitação, movimento giratório da cabeça, batimento das asas, incoordenação, com alguns animais querendo bicar a pessoa que realizava a sua contenção. Apenas dois animais (números 4 e 6) permaneceram imóveis durante todo o período de recuperação anestésica, mantendo os olhos abertos, observando o que ocorria a sua volta, mas impossibilitados de movimentos.

\subsubsection{Dose Anestésica Utilizada}

Cada animal foi anestesiado, utilizando-se, a princípio, as doses préestabelecidas de $53,3 \mathrm{mg} / \mathrm{kg}$ de cloridrato de quetamina e $4,7 \mathrm{mg} / \mathrm{kg}$ de cloridrato de xilazina. Porém, alguns animais não sedaram, necessitando de dose adicional. Em outros casos, foi preciso arredondar a dose em volumes, seja para mais ou para menos porque, mesmo utilizando-se uma seringa de insulina de 30 unidades $(0,3 \mathrm{cc})$, algumas doses eram difíceis de serem quantificadas com precisão. Deste modo, por exemplo, doses de quetamina de $0,086 \mathrm{ml}$ eram arredondadas para $0,085 \mathrm{ml}$, e doses como $0,088 \mathrm{ml}$ eram arredondadas para $0,09 \mathrm{ml}$, e assim sucessivamente.

As doses anestésicas utilizadas no experimento definitivo estão relacionadas na Tabela 5 . 
Tabela 5 - Dose anestésica utilizada no experimento definitivo.

\begin{tabular}{cccc}
\hline Identificação do animal & \multicolumn{2}{c}{ Dose anestésica $(\mathbf{m g} / \mathbf{k g})$} & Peso do animal $(\mathbf{g})$ \\
\cline { 2 - 3 } & quetamina & xilazina & 188 \\
\hline 1 & 53,2 & 4,6 & 194 \\
2 & 51,5 & 4,6 & 166 \\
3 & 51,2 & 4,2 & 166 \\
$4^{*}$ & 57,2 & 4,8 & 171 \\
5 & 52,6 & 4,7 & 203 \\
6 & 53,2 & 4,6 & 180 \\
7 & 53,3 & 4,7 & 154 \\
$8^{*}$ & 69,5 & 5,8 & 169 \\
9 & 53,25 & 4,7 & 144 \\
$10^{*}$ & 59 & 5,5 & 173,5 \\
Média & 55,4 & 4,8 & 18,1 \\
Desvio-padrão & 5,5 & 0,5 & 5,7 \\
Erro-padrão & 1,7 & 0,1 & 144,0 \\
Mínimo & 51,2 & 4,2 & 203,0 \\
Máximo & 69,5 & 5,8 & \\
\hline *Animais que receberam dose adicionat & & \\
\hline
\end{tabular}

\subsubsection{Período de Latência e Período Hábil Anestésico}

A partir do momento em que os anestésicos foram administrados, observouse o tempo que cada animal levava para apresentar os primeiros sinais de sedação (período de latência). Decorrido o período de latência, registrou-se quanto tempo cada animal levava para o retorno do tônus muscular, sendo este o parâmetro usado neste experimento para determinar o término do período hábil anestésico.

Os períodos de latência e os períodos hábeis anestésicos dos animais do experimento estão relacionados na Tabela 6 .

Tabela 6 - Período de latência e período hábil anestésico.

\begin{tabular}{lccc}
\hline \multicolumn{2}{c}{ Identificação do animal } & Período de latência (s) & Período hábil anestésico (min) \\
\hline 1 & 29 & 60 \\
& 2 & 60 & 134 \\
& 3 & 54 & 49 \\
& 4 & 150 & 67 \\
& 5 & 90 & 68 \\
& 6 & 92 & 133 \\
& 7 & 60 & 56 \\
& 8 & 111 & 83 \\
& 9 & 55 & 56 \\
Média & 10 & 180 & 57 \\
Desvio-padrão & 94,1 & 76,3 \\
Erro-padrão & 42,6 & 31,5 \\
Mínimo & 13,5 & 10,0 \\
Máximo & 54,0 & 49,0 \\
\hline
\end{tabular}




\subsection{Avaliação do Exame Tomográfico}

\subsubsection{Tempo de Duração do Exame Tomográfico}

O tempo de duração do exame tomográfico começou a ser contado a partir da administração do anestésico no animal, incluindo o seu posicionamento na bandeja, bobina e tomógrafo, ajustes do equipamento e aquisição das imagens. Em quase todos os casos, o retorno do tônus muscular foi o que determinou o término de aquisição das imagens, uma vez que, a partir da movimentação do animal dentro do tomógrafo, não era mais possível a aquisição de imagens de qualidade. Naqueles animais em que o retorno do tônus muscular foi mais tardio, procurou-se adquirir imagens coronais em, pelo menos, três inclinações diferentes. A contagem do tempo de duração do exame se encerrou quando o animal foi retirado do tomógrafo. Abaixo, encontram-se relacionados o tempo de duração do exame de cada animal do experimento (Tabela 7) e o tempo que levaria, se em todos os animais fossem realizadas as três inclinações dos cortes coronais (Tabela 8).

Tabela 7 -Tempo de duração do exame tomográfico.

\begin{tabular}{lccc}
\hline \multicolumn{1}{c}{ Identificação do animal } & $\begin{array}{c}\text { Tempo total do exame } \\
\text { tomográfico (min.) }\end{array}$ & $\begin{array}{c}\text { Número de aquisições } \\
\text { coronais }\end{array}$ \\
\hline & 1 & 62 & 3 \\
& 2 & 60 & 3 \\
& 3 & 58 & 3 \\
& 4 & 70 & 2 \\
& 5 & 75 & 3 \\
& 6 & 65 & 3 \\
& 7 & 65 & 3 \\
& 8 & 85 & 4 \\
& 9 & 57 & 3 \\
\hline Média & 10 & 65 & \\
Desvio-padrão & & 66,2 & \\
Erro-padrão & 8,5 & \\
Mínimo & 2,7 & \\
Máximo & 57,0 & \\
\hline
\end{tabular}


Tabela 8 - Tempo de duração do exame tomográfico se fossem realizadas 3 aquisições de imagens coronais para cada animal.

\begin{tabular}{lccc}
\hline Identificação do animal & $\begin{array}{c}\text { Tempo total do exame } \\
\text { tomográfico (min.) }\end{array}$ & $\begin{array}{c}\text { Número de aquisições } \\
\text { coronais }\end{array}$ \\
\hline & 1 & 62 & 3 \\
& 2 & 60 & 3 \\
& 3 & 58 & 3 \\
& 4 & 78 & 3 \\
& 5 & 75 & 3 \\
& 6 & 65 & 3 \\
& 7 & 65 & 3 \\
\hline Média & 8 & 77 & 3 \\
Desvio-padrão & 9 & 57 & 3 \\
Erro-padrão & 10 & 65 & 3 \\
Mínimo & 66,2 & \\
Máximo & 7,8 & \\
\hline
\end{tabular}

\subsubsection{Interpretação das Imagens Tomográficas}

Pela comparação de imagens tomográficas das aves utilizadas nesta pesquisa com a anatomia normal de aves silvestres (literatura) e imagens tomográficas adquiridas de uma peça anatômica (contendo rins e testículos de Arara Canindé adulta, fixados em formol a 10\%) (Figura 30 e 31), foi possível, por meio da forma e da topografia, identificar os testículos dos animais números 1, 6 e 8 (Figura 32).

Nos animais números 2 e 7, devido ao tamanho reduzido dos testículos, e por estarem suspensos da parede dorsal do corpo sobre a mesma localização das glândulas adrenais (Figura 3b), não foi possível afirmar com certeza se as estruturas observadas se referiam às gônadas ou às adrenais, uma vez que estruturas muito semelhantes também foram visualizadas nas fêmeas (Figura 33). Entretanto, o formato anatômico do ovário esquerdo nas fêmeas (animais números 3, 4, 5, 9 e 10) não permitiu uma caracterização precisa desse órgão com imagens tomográficas ponderadas por densidade de prótons (Figura 34). 


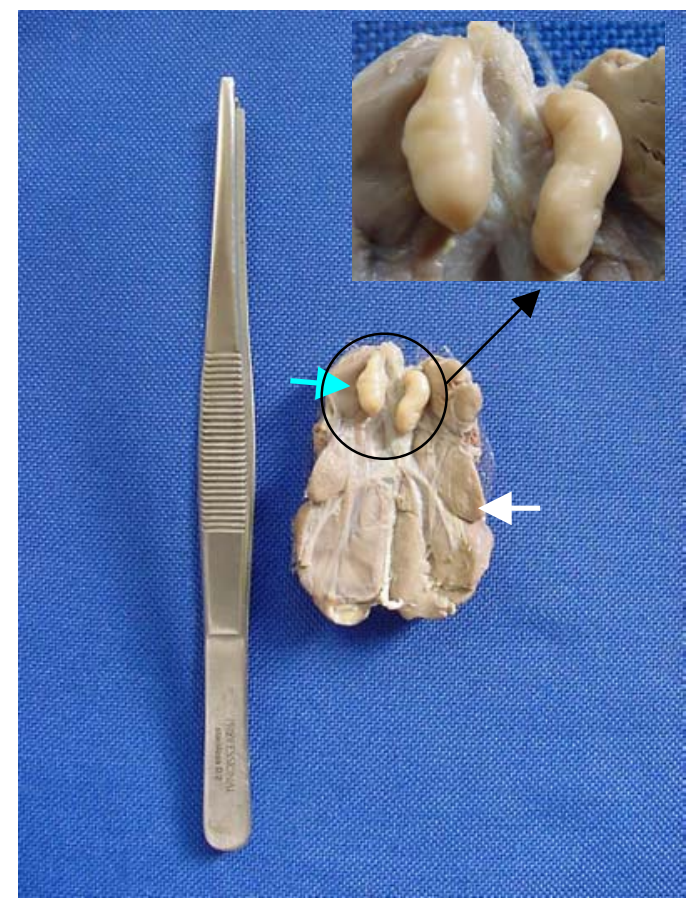

Figura 30 - Rins (seta branca) e testículos (seta azul) de Arara Canindé (Ara ararauna), fixados em formol a $10 \%$. Em destaque, os testículos.

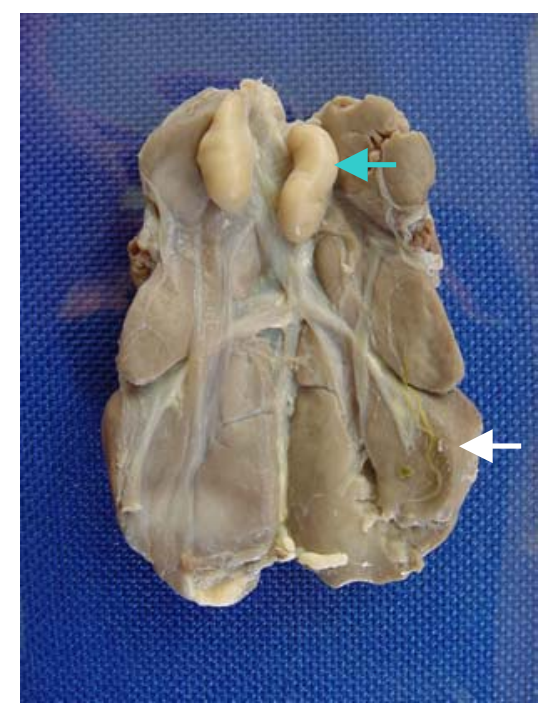

a)

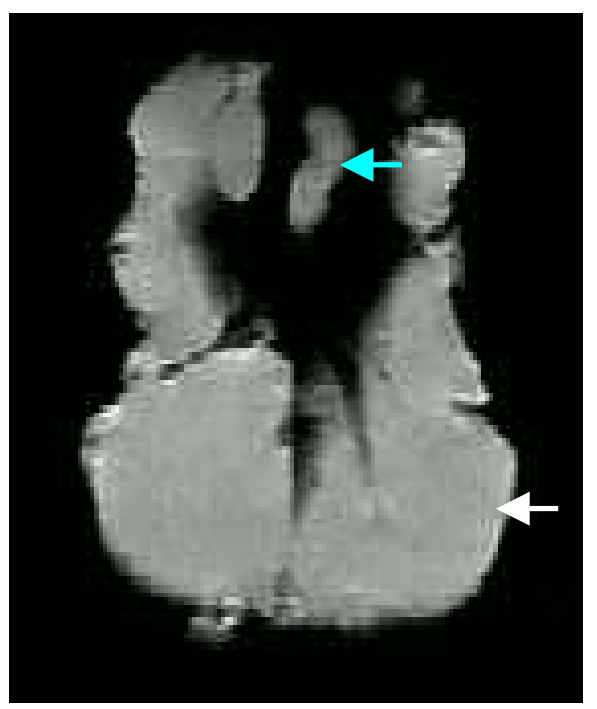

b)

Figura 31 - a) Rins (seta branca) e testículos (seta azul) de Arara Canindé (Ara ararauna), fixados em formol a $10 \%$; b) Imagem tomográfica dos rins (seta branca) e testículos (seta azul) de Arara Canindé, fixados em formol a 10\%. Campo de visão: $6 \mathrm{~cm} \times 8 \mathrm{~cm}$. 


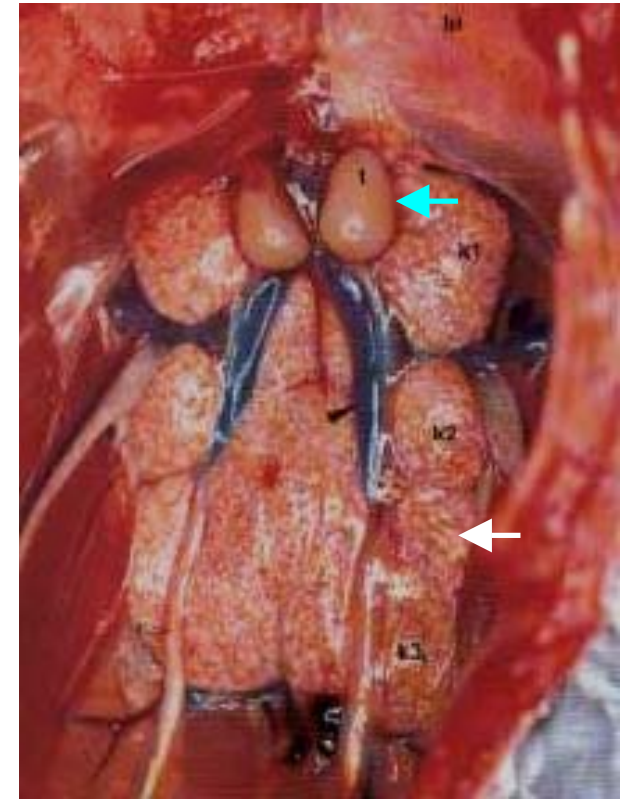

a)

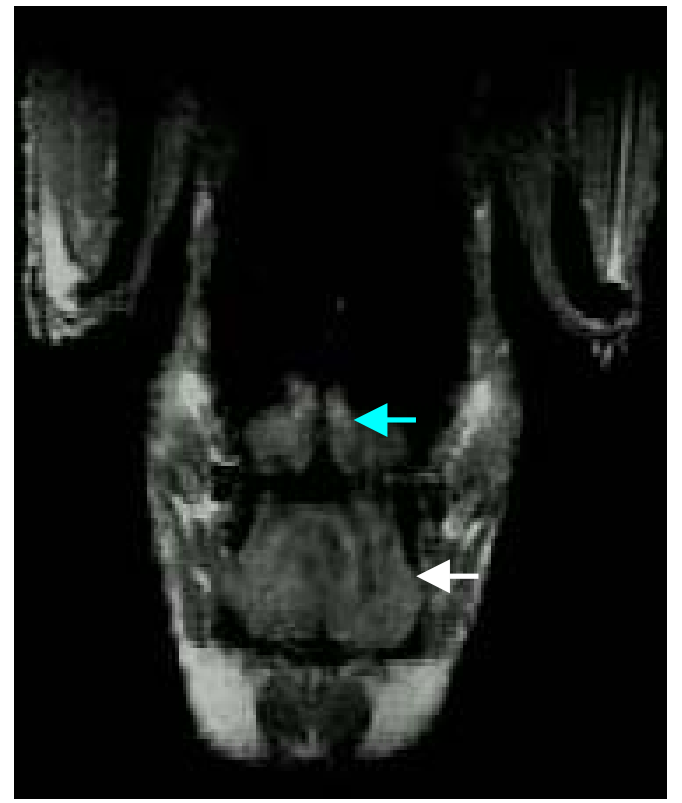

b)

Figura 32 - a) Rins (seta branca) e testículos (seta azul) de papagaio cinza africano (Psittacus erithacus) macho, em época reprodutiva ${ }^{[110]}$; b) Imagem tomográfica dos rins (seta branca) e testículos (seta azul) de um periquitão-maracanã (Aratinga leucophthalmus) macho, em época reprodutiva. Campo de visão: $7 \mathrm{~cm}$ x $14 \mathrm{~cm}$.

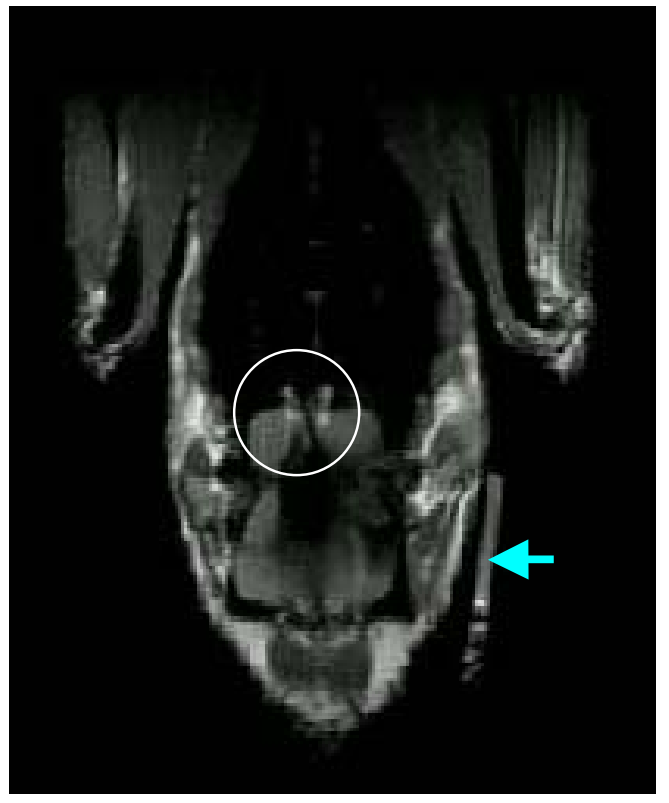

a)

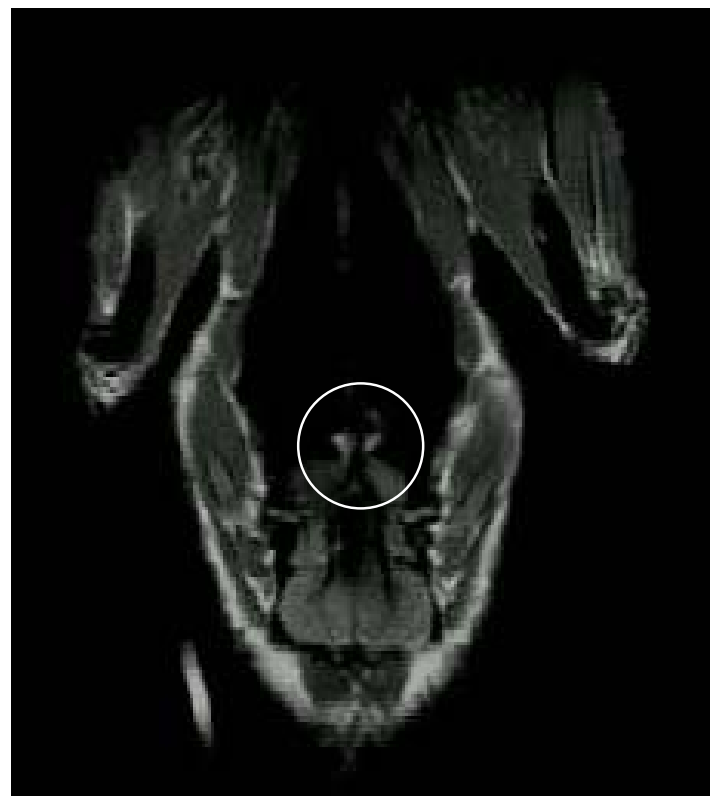

b)

Figura 33 - a) Imagem tomográfica do animal número 7 - periquitão-maracanã (Aratinga leucophthalmus) macho; b) Imagem tomográfica do animal número 9 periquitão-maracanã (Aratinga leucophthalmus) fêmea. $O$ círculo destaca a região anatômica em que os testículos (no macho) e as glândulas adrenais (em ambos) estão localizados. A seta azul indica o tubo contendo óleo, que determina o lado esquerdo da imagem. Campo de visão: $7 \mathrm{~cm} \times 14 \mathrm{~cm}$. 


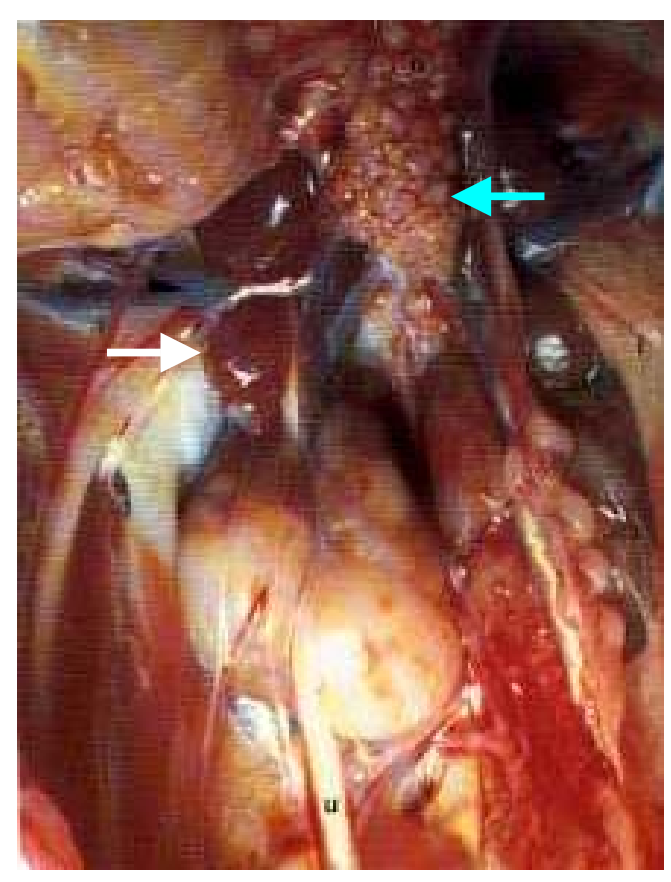

a)

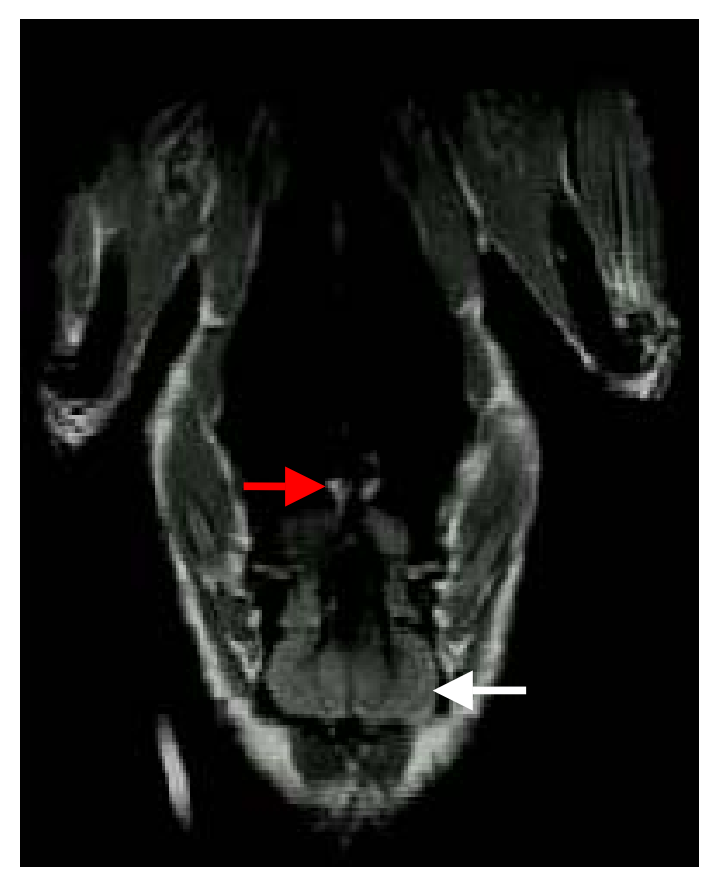

b)

Figura 34 - a) Rins (seta branca) e ovário esquerdo (seta azul) de fêmea madura sexualmente, de papagaio cinza africano (Psittacus erithacus) ${ }^{[110]}$; b) Imagem tomográfica dos rins (seta branca) e glândulas adrenais (seta vermelha) de um periquitãomaracanã (Aratinga leucophthalmus) fêmea. Campo de visão: $7 \mathrm{~cm} \times 14 \mathrm{~cm}$.

\subsection{Exame de Polimorfismo de DNA}

Os resultados do exame de polimorfismo de DNA estão relacionados na Tabela 9.

Tabela 9 - Resultado do exame de polimorfismo de DNA.

\begin{tabular}{cc}
\hline Identificação do animal & Resultado do exame de polimorfismo de DNA \\
\hline 1 & macho \\
2 & macho \\
3 & fêmea \\
4 & fềea \\
5 & fêmea \\
6 & macho \\
7 & macho \\
8 & macho \\
9 & fêmea \\
10 & fêmea \\
\hline
\end{tabular}




\section{Discussão}

A associação anestésica de cloridrato de quetamina e cloridrato de xilazina, nas doses utilizadas neste estudo, mostrou-se uma boa opção anestésica para a espécie Aratinga leucophthalmus, atingindo o objetivo esperado de promover um período hábil anestésico viável à realização do exame tomográfico. Essa associação promoveu a imobilidade das aves durante todo o período de aquisição das imagens, e não ocasionou dano ou reação indesejável aos animais (excetuando aquelas reações já esperadas para o anestésico). Segundo RUPLEY [111], poucos estudos farmacológicos têm sido realizados sobre as drogas normalmente utilizadas na medicina aviária. A maioria das doses encontradas na literatura se baseia em experiência clínica ou é extrapolada a partir do uso em outras espécies. Portanto, acredita-se que este trabalho trouxe a sua contribuição à clínica aviária ao acrescentar novas informações acerca desses anestésicos.

O protocolo utilizado para a realização do exame tomográfico das aves em estudo (partindo desde o transporte até a recuperação anestésica) apresentou excelentes resultados, não havendo, em momento algum, qualquer tipo de dano à saúde dos animais. Todas as aves retornaram ao cativeiro sem apresentar efeito colateral que pudesse ser atribuído ao protocolo ao qual foram submetidas.

Quanto aos resultados do exame tomográfico, o tempo total do exame ficou em torno de 66 minutos, sendo que, o tempo gasto para a aquisição das imagens foi de aproximadamente 26 minutos para 3 aquisições coronais, podendo ser reduzida para apenas uma aquisição, e os 40 minutos restantes corresponderam ao procedimento anestésico, posicionamento da ave e ajustes do equipamento, tempo este, que pode ser reduzido, uma vez que o profissional se torne mais familiarizado com as etapas do protocolo de exame. Esse tempo gasto para a realização do exame tomográfico (66 min) pode ser considerado aceitável, quando comparado àquele obtido por VERHOYE et al. ${ }^{[85]}$ no estudo do cérebro do canário e do estorninho 
europeu, utilizando a TRMN 3D. Segundo esses autores, para o protocolo de exame completo, incluindo o posicionamento da ave e preparação dos instrumentos de TRMN, foi necessário um período de anestesia de aproximadamente 120 minutos.

Quanto à interpretação das imagens tomográficas, foi possível a identificação dos testículos de aves da espécie Aratinga lecophthalmus por meio de imagens coronais ponderadas por densidade de prótons, utilizando-se tomógrafo de 2T. Porém, em dois animais do sexo masculino (confirmados pelo exame de polimorfismo de DNA), devido ao tamanho reduzido dos testículos, e por estarem suspensos da parede dorsal do corpo sobre a mesma localização das glândulas adrenais, não foi possível afirmar com certeza se as estruturas observadas se referiam às gônadas ou às adrenais. Sabe-se que os testículos são diminutos em aves sexualmente imaturas e em aves maduras, após um período de estimulação sexual. Em contrapartida, aves maduras sexualmente apresentam aumento dos testículos durante a época de procriação (embora, em psitacídeos, o tamanho máximo dos testículos, durante a estimulação sexual, não seja tão grande, se comparado a outras espécies). Segundo comunicação pessoal com a equipe do CETAS de São Carlos, o período de procriação da espécie Aratinga leucophthalmus ocorre por volta dos meses de setembro a janeiro na região de São Carlos (São Paulo). Nesse mesmo período foram realizados os exames tomográficos dos animais em estudo. Portanto, uma vez que esses animais estavam em fase de estimulação sexual, as aves maduras sexualmente deveriam apresentar aumento de tamanho de suas gônadas. Assim sendo, presume-se que as aves números 2 e 7, nas quais devido ao tamanho reduzido dos testículos não foi possível afirmar com certeza se as estruturas observadas se referiam às gônadas ou às adrenais, provavelmente eram animais ainda sexualmente imaturos. Outros métodos de sexagem também possuem a limitação de somente poderem ser realizados em animais que já atingiram a maturidade sexual, como é o caso da laparoscopia e da análise fecal. Como regra geral, as gônadas se tornam maduras, na maioria das aratingas, entre dezoito meses e dois anos de idade.

No caso das fêmeas, o formato anatômico do ovário esquerdo não permitiu uma caracterização precisa desse órgão por meio de imagens coronais ponderadas por densidade de prótons, utilizando-se tomógrafo de 2T. Como esses animais estavam em estação reprodutiva, era esperado que as aves maduras sexualmente 
apresentassem ovários com desenvolvimento folicular, os quais provavelmente seriam visualizados, uma vez que a gema da ave em procriação ocupa uma considerável porção da cavidade abdominal (Figura 6). Porém, o ovário de uma ave imatura não apresenta folículos, fato que pode fazer a diferenciação entre ele e um testículo difícil. Neste caso, o ovário se apresenta achatado e pode ser facilmente confundido com tecido adiposo. Certamente por isso não foram precisamente caracterizados neste estudo.

Da mesma forma, ROMAGNANO et al. ${ }^{[83]}$ no estudo do cérebro e cavidade celomática de pombas domésticas utilizando-se a TRMN com um equipamento de 1,5T, relataram que não foi possível distinguir, com segurança, o ovário do mesentério adjacente e intestino delgado por meio das imagens de ressonância magnética, mas a sua presença foi confirmada por comparação com secções anatômicas. Cabe ressaltar que, se em aves como as pombas domésticas, que segundo VIELLIARD (apud FÁVARO, 2002) ${ }^{[112]}$, apresentam grande capacidade reprodutiva, podendo realizar a postura de ovos até sete vezes no mesmo ano, a visualização do ovário já não foi possível, acredita-se que em psitacídeos, que apresentam espécies que sequer chegam a nidificar e produzir descendentes todos os anos na natureza, como é o caso das araras ${ }^{[12]}$, essa visualização seja ainda muito mais difícil. Reforçando o afirmado acima, em ensaios tomográficos realizados em pombo macho observou-se um tamanho relativamente maior dos testículos dessa ave, quando comparados aos testículos dos psitacídeos utilizados neste estudo, sendo que ambas as espécies apresentavam praticamente o mesmo tamanho e peso corpóreo (dados não publicados). Porém, CZISCH et al. ${ }^{[89]}$ visualizaram o ovário de uma fêmea de pássaro canoro (Sylvia borin) por meio de TRMN, mas para isso utilizaram um tomógrafo de $7 \mathrm{~T}$, operando em uma freqüência de $300 \mathrm{MHz}$, sendo que os campos utilizados para imagens médicas variam de 0,5 a $2 \mathrm{~T}$.

Quanto aos parâmetros utilizados para a aquisição das imagens deste estudo, bem como os planos tomográficos e a bobina utilizada (tipo gaiola), geraram imagens de grande qualidade.

A TRMN, como opção de um novo método de sexagem para aves silvestres que não apresentam dimorfismo sexual, mostrou-se uma técnica rápida, uma vez que as imagens, ao serem adquiridas, já podem ser interpretadas. É uma técnica não- 
invasiva, indolor (a não ser pela pequena picada da agulha na administração do anestésico), e que ainda permite a visualização dos demais órgãos, podendo, no mesmo exame, também ser realizado o diagnóstico de uma série de patologias dos animais que estão sendo sexados.

O uso da anestesia para esse tipo de exame não pode ser considerado como um fator limitante porque, como citado por RUPLEY ${ }^{[113]}$, até mesmo para a realização de uma simples radiografia as aves normalmente são anestesiadas (para evitar lesões nos animais e a exposição pessoal às radiações). Em um outro método de sexagem muito utilizado, a laparoscopia, os animais também precisam ser anestesiados.

Quanto ao custo do exame tomográfico, verificou-se ser de preço acessível, se comparado aos outros métodos comumente usados para sexagem. Na Tabela 10 estão demonstradas as características de cada método, comparados à TRMN.

Tabela - 10 Comparação da TRMN com os principais métodos utilizados para sexagem de aves.

\begin{tabular}{|c|c|c|c|c|}
\hline & TRMN & Laparoscopia & Análise de DNA & Cariot \\
\hline $\begin{array}{l}\text { Valor do exame/ave } \\
\text { Invasiva }\end{array}$ & $\begin{array}{c}\mathrm{R} \$ 100,00 / \mathrm{h} \\
\text { não }\end{array}$ & $\begin{array}{c}\text { US\$ } 10-15 \bullet \\
\text { sima }\end{array}$ & $\begin{array}{r}\mathrm{R} \$ 45 \\
\text { não }\end{array}$ & $0,00 *$ \\
\hline $\begin{array}{l}\text { Tempo necessário para } \\
\text { obtenção do resultado }\end{array}$ & poucos minutos & poucos minutos & 9 dias* & 20 dias* \\
\hline Porte d & & & & \\
\hline Idade & & & & \\
\hline \multicolumn{5}{|c|}{$\begin{array}{l}\text { Gasto do tomógrafo: } \mathrm{R} \$ 100,00 / \mathrm{h} \text { (valor estipulado pela Embrapa Instrumentação Agropecuária para prestação de } \\
\text { serviços). Nesse valor não está incluída a mão de obra do veterinário radiologista. } \\
\text { C Comunicação pessoal - Carlos Yamshita (mestre - IBAMA). } \\
\text { * Foi realizada uma pesquisa de mercado, em laboratórios particulares dos estados de São Paulo, Minas Gerais e Rio } \\
\text { Grande do Sul. Portanto, os preços e tempo necessário para obtenção dos resultados correspondem a uma média desta pesquisa } \\
\text { • [12,13]. } \\
\quad[15,18] \text {. } \\
\quad \text { * }[12,13,15] \text {. }\end{array}$} \\
\hline
\end{tabular}

Como citado por FRANCISCO et al. ${ }^{[5]}$, o trabalho conjunto de zoológicos, criadores e instituições de pesquisa deve ser incentivado, a fim de que, em parceria, possam contribuir para a conservação da avifauna brasileira, uma vez que informações adicionais desses animais tão pouco estudados, somente vêm a acrescentar nesta luta. Acredita-se, portanto, que este trabalho venha a colaborar para a preservação de aves silvestres sem dimorfismo sexual, trazendo novas informações a respeito desses animais. 
Espera-se com este estudo ter criado novas perspectivas na área de sexagem de aves silvestres, bem como na área de diagnóstico veterinário por imagem. 


\section{Conclusão}

Considerando-se os resultados obtidos neste trabalho experimental, pode-se concluir que o uso da TRMN para a sexagem de aves silvestres sem dimorfismo sexual se mostrou um método rápido, não-invasivo, indolor e eficiente para a identificação dos testículos de aves da espécie Aratinga leucophthalmus, maduras sexualmente, em fase de estimulação sexual. 


\section{Referências Bibliográficas}

1. LEAL, A. Fauna brasileira em extinção. Disponível em: $<$ http://www.ibamapb.hpg.com.br/extincao.htm> Acesso em: 15 mar. 2001.

2. PEREIRA, P. (2002). Um crime que passa despercebido. Revista Galileu, ano 11, n.127, p.24-33, fev.

3. SICK, H. (1997). Ornitologia brasileira. Rio de Janeiro, Nova Fronteira. p.351382: Famílias e espécies - ordem psittaciformes.

4. ROMA, J.C. (2000). A diversidade da avifauna brasileira. In: Brasil 500 pássaros. Brasília, DF, Eletronorte. p.251.

5. FRANCISCO, M.R.; LUNARDI, V.O.; GALETTI JÚNIOR, P.M. (2000). Sexagem cromossômica e conservação de aves. São Carlos. Informativo Técnico - Centro de Ciências Biológicas e da Saúde, Departamento de Genética e Evolução, Laboratório de Citogenética, Universidade Federal de São Carlos. /folder/

6. BRASIL. Leis, etc. (1991). Legislação ambiental brasileira, Portaria 005/91 - N, de 25 de abril de 1991. Diário Oficial da União, Brasília, DF, 26 abr. Seção I, p.7796.

7. PENCE, P.A. (1996). Nonsurgical sexing technology. In: ROSSKOPF JR., W.J.; WOERPEL, R.W. Diseases of cage and aviary birds. Baltimore, Williams \& Wilkins. p.851-856.

8. CENSO de animais. (2000). Psittacidae. /Censo da Sociedade de Zoológicos do Brasil - SZB/

9. DIMORFISMO sexual. In: FERREIRA, A.B.H. (1986). Novo dicionário Aurélio da língua portuguesa. Rio de Janeiro, Nova Fronteira. p.591.

10. GRUBER, A. Sexagem de aves monomórficas por PCR. (transparência). São Paulo. 17 transparências, color.

11. MCDONALD, S.E. (1996). Endoscopy. In: ROSSKOPF JR., W.J.; WOERPEL, R.W. Diseases of cage and aviary birds. Baltimore, Williams \& Wilkins. p.699-717. 
12. RUPLEY, A.E. (1999). Manual de clínica aviária. São Paulo, Roca. p.495-517: Avicultura e obstetrícia.

13. TOMASUlO, A.M. (1998). Identificação do sexo em aves da ordem ciconiinformes utilizando a técnica de PCR. São Carlos. 40p. Dissertação (Mestrado) - Centro de Ciências Biológicas e da Saúde, Universidade Federal de São Carlos.

14. LUCCA, E.J.; ROCHA, G.T. (1992). Citogenética de aves. Boletim do Museu Paraense Emílio Goeldi-Série Zoologia, v.8, n.1, p.33-68.

15. GIANNONI, M.L.; GIANNONI, M.A.; FERRARI, I. (1986). Citogenética aplicada às aves: técnicas. Piracicaba, FEALQ. p.7-52: Obtenção de metáfases.

16. GÔNADA. In: FERREIRA, A.B.H. (1986). Novo dicionário Aurélio da língua portuguesa. Rio de Janeiro, Nova Fronteira. p.857.

17. SEXAGEM de aves: o teste de DNA para a sexagem de aves. Disponível em: $<$ http://www.citocel.com.br/ind_04.htm> Acesso em: 27 set. 2001.

18. MAIA, J.S.; TOLEDO,M.C.B. Análise de dados morfométricos para Paroaria capitata objetivando a possibilidade da sexagem pela morfometria. Disponível

em:

$<$ http://www.unitau.br/prppg/inicient/iveic/resubioc/bioc05.htm> Acesso em: 16 fev. 2001.

19. INTERAÇÃO entre poluição e endocrinologia reprodutiva de lontras (Lontra longicaudis). Disponível em: $<$ http://www.octopus.furg.br/pesquisa/Projetos/lontras.htm> Acesso em: 16 fev. 2001.

20. SICK, H. (1997). Ornitologia brasileira. Rio de Janeiro, Nova Fronteira. p.5977: Conservação.

21. HILDEBRANDT, T.; PITRA, C.; SÖMMER, P.; PINKOWSKI, M. (1995). Sex identification in birds of prey by ultrasonography. Journal of Zoo and Wildlife Medicine, v.26, n.3, p.367-376.

22. HILDEBRANDT, T.B.; GÖRITZ, F.; BOSCH, H.; SEIDEL, B.; PITRA, C. (1996). Ultrasonographic sexing and reproductive assessment of penguins. Penguin Conservation, v.9, n.1, p.6-12, Apr.

23. EVANS, H.E. (1969). Anatomy of the budgerigar. In: PETRAK, M.L. Diseases of cage and aviary birds. Philadelphia, Lea \& Febiger. p.45-112. 
24. EVANS, H.E. (1996). Anatomy of the budgerigar and other birds. In: ROSSKOPF JR., W.J.; WOERPEL, R.W. Diseases of cage and aviary birds. Baltimore, Williams \& Wilkins. p.79-162.

25. MAINA, J.N. (1996). Perspectives on the structure and function in birds. In: ROSSKOPF JR., W.J.; WOERPEL, R.W. Diseases of cage and aviary birds. Baltimore, Williams \& Wilkins. p.163-217.

26. BENEZ, S.M. (1998). Aves: criação-clínica-teoria-prática, silvestres ornamentais avinhados. São Paulo, Robe Editorial. p.18-91: Anatomia e fisiologia das aves.

27. SICK, H. (1997). Ornitologia brasileira. Rio de Janeiro, Nova Fronteira. p.8492: Morfologia.

28. KING, A.S. (1986). Aparelho urogenital das aves. In: GETTY, R. Sisson/Grossman: anatomia dos animais domésticos. Rio de Janeiro, Guanabara Koogan. p.1798-1839.

29. WELTY, J.C.; BAPTISTA, L. (1988). The life of birds. USA, Saunders College. p.142-170: Excretion, reproduction, and photoperiodism.

30. AVES em extinção. Disponível em: $<$ http://www.mma.gov.br/port/cgmi/meioambi/ar/avesext/index.html> Acesso em: 08 fev. 2001.

31. ZUCCHI, M.R. (1997). Implementação da técnica de espectroscopia in vivo por RMN e sua aplicação na fisiologia do exercício. São Carlos. 69p. Dissertação (Mestrado) - Instituto de Física de São Carlos, Universidade de São Paulo.

32. ROSENBERG, L.A.; MAGALHÃES, A.C.A. (1993). Ressonância magnética. In: DANI, R.; CASTRO, L.P. Gastroenterologia clínica. Rio de Janeiro, Guanabara Koogan. p.134-140.

33. KÄRKKÄINEN, M. (1995). Low -and high- field strength magnetic resonance imaging to evaluate the brain in one normal dog and two dogs with central nervous system disease. Veterinary Radiology \& Ultrasound, v.36, n.6, p.528-532, Nov./Dec.

34. BACHESCHI, L.A.; MATHIAS, S.C. (1999). Infecções virais do sistema nervoso central. In: MAGALHÃES, A.C.A. Ressonância magnética do sistema nervoso central. São Paulo, Atheneu. p.111-118.

35. TERRAZAN, E.A. (1989). Radiações. Revista de Ensino de Ciências, n.22, p.111 , jul. 
36. PRADO, G.L.M. Fundamentos de ressonância magnética. Hirosaki University School of Medicine - Hirosaki University Hospital - Departament of Radiology. Disponível em: $<$ http://www.imaginologia.com.br/teses/004/index.htm> Acesso em: 21 jan. 2001.

37. FOERSTER, B. (1994). Técnicas de aquisição rápida em tomografia por ressonância magnética nuclear. São Carlos. 120p. Dissertação (Mestrado) Instituto de Física e Química de São Carlos, Universidade de São Paulo.

38. KODAIRA, S. (1999). Princípios físicos e instrumentação. In: MAGALHÃES, A.C.A. Ressonância magnética do sistema nervoso central. São Paulo, Atheneu. p.1-8.

39. VIDOTO, E.L.G. (1995). Projeto de transdutores e otimização do sistema de recepção do tomógrafo RMN de campo magnético ultra baixo. São Carlos. 116p. Dissertação (Mestrado) - Instituto de Física de São Carlos, Universidade de São Paulo.

40. PANEPUCCI, H.; DONOSO, J.P.; TANNÚS, A.; BECKMANN, N.; BONAGAMBA, T.J. (1985). Tomografia por ressonância magnética nuclear: novas imagens do corpo. Ciência Hoje, v.4, n.20, p.46-56, set./out.

41. MENEZES NETO, J.R. (1999). Bases anatômicas, fisiológicas e patológicas. In: MAGALHÃES, A.C.A. Ressonância magnética do sistema nervoso central. São Paulo, Atheneu. p.9-26.

42. BELLON, E.M.; DIAZ, P.J. (1996). Física da ressonância magnética: introdução. In: HAAGA, J.R.; LANZIERI, C.F.; SARTORIS, D.J.; ZERHOUNI, E.A. Tomografia computadorizada e ressonância magnética do corpo humano. Rio de Janeiro, Guanabara Koogan. p.23-32.

43. AZEVÊDO, E.R. (1998). Efeitos do movimento em imagens por RMN e implementação das técnicas "gradient moment nulling" e pré-saturação espacial para redução de artefatos relacionados ao movimento. São Carlos. 116p. Dissertação (Mestrado) - Instituto de Física de São Carlos, Universidade de São Paulo.

44. RIBEIRO, R.F.; MAGALHÃES, A.C.A. (1999). Articulação temporomandibular: imagens por ressonância magnética. In: MAGALHÃES, A.C.A. Ressonância magnética do sistema nervoso central. São Paulo, Atheneu. p.249-265.

45. SU SIH LO, L. (1999). Tumores intra-axiais. In: MAGALHÃES, A.C.A. Ressonância magnética do sistema nervoso central. São Paulo, Atheneu. p.73-90. 
46. HANDFAS, B.W. (1999). Ressonância magnética no infarto cerebral. In: MAGALHÃES, A.C.A. Ressonância magnética do sistema nervoso central. São Paulo, Atheneu. p.53-72.

47. DANIEL, M.M.; LORENZI, M.C.; ROSEMBERG, L.A. (1999). Ressonância magnética da face. In: MAGALHÃES, A.C.A. Ressonância magnética do sistema nervoso central. São Paulo, Atheneu. p.187-197.

48. DANIEL, M.M.; ROSEMBERG, L.A. (1999). Ressonância magnética da faringe e do pescoço. In: MAGALHÃES, A.C.A. Ressonância magnética do sistema nervoso central. São Paulo, Atheneu. p.199-207.

49. ABDO, C.H.N.; NICASTRI, S.; RAMADAN, Z.B.A. (1999). Ressonância magnética em psiquiatria. In: MAGALHÃES, A.C.A. Ressonância magnética do sistema nervoso central. São Paulo, Atheneu. p.283-294.

50. O QUE VOCÊ deve saber sobre ressonância magnética. Disponível em: $<$ http://www.cetac.com.br/ressona.htm> Acesso em: 21 jan. 2001.

51. PREVENTIVE care: advances in veterinary medical technology. Disponível em: $<$ http://www.healthypet.com/Library/prevent-23.html> Acesso em: $22 \mathrm{fev}$. 2002.

52. MCCONNELL, F. (2000). Disponível em: $<$ http://www.vetstream.co.uk/v2000/community/article_imaging.htm> Acesso em: 22 fev. 2002.

53. KRAFT, S.L.; GAVIN, P.R.; WENDLING, L.R.; REDDY, V.K. (1989). Canine brain anatomy on magnetic resonance images. Veterinary Radiology, v.30, n.1, p.147-158.

54. BAIRD, D.K.; HATHCOCK, J.T.; RUMPH, P.F.; KINCAID, S.A.; VISCO, D.M. (1998). Low-field magnetic resonance imaging of the canine stifle joint: normal anatomy. Veterinary Radiology \& Ultrasound, v.39, n.2, p.8797, Mar./Apr.

55. PHARR, J.W.; TRYON, K.A.; KENDALL, E.J. Magnetic resonance imaging of non-disc diseases of the canine spine. /Apresentado ao EAVDI/ECVDI Annual Meeting, Paris, 2001/

56. ALL-CARE ANIMAL REFERRAL CENTER. Needs an MRI. Disponível em: $<$ http://www.acarc.com/mri.htm> Acesso em: 22 fev. 2002.

57. MORGAN, R.; DANIEL, G.B.; DONNELL, R.L. (1994). Magnetic resonance imaging of the normal eye and orbit of the dog and cat. Veterinary Radiology \& Ultrasound, v.35, n.2, p.102-109, Mar./Apr. 
58. HUDSON, L.C.; CAUZINILLE, L.; KORNEGAY, J.N.; TOMPKINS, M.B. (1995). Magnetic resonance imaging of the normal feline brain. Veterinary Radiology \& Ultrasound, v.36, n.4, p.267-275, July/Aug.

59. NEWELL, S.M.; GRAHAM, J.P.; ROBERTS, G.D.; GINN, P.E.; CHEWNING, C.L.; HARRISON, J.M.; ANDRZEJEWSKI, C. (2000). Quantitative magnetic resonance imaging of the normal feline cranial abdomen. Veterinary Radiology \& Ultrasound, v.41, n.1, p.27-34, Jan./Feb.

60. SAMII, V.F.; BILLER, D.S.; KOBLIK, P.D. (1999). Magnetic resonance imaging of the normal feline abdomen: an anatomic reference. Veterinary Radiology \& Ultrasound, v.40, n.5, p.486-490, Sept./Oct.

61. ALLGOEWER, I.; LUCAS, S.; SCHMITZ, S.A. (2000). Magnetic resonance imaging of the normal and diseased feline middle ear. Veterinary Radiology \& Ultrasound, v.41, n.5, p.413-418, Sept./Oct.

62. ARENCIBIA, A.; VAZQUEZ, J.M.; RAMIREZ, J.A.; RAMIREZ, G.; VILAR, J.M.; RIVERO, M.A.; ALAYON, S.; GIL, F. (2001). Magnetic resonance imaging of the normal equine brain. Veterinary Radiology \& Ultrasound, v.42, n.5, p.405-409, Sept./Oct.

63. CHAFFIN, M.K.; WALKER, M.A.; MCARTHUR, N.H.; PERRIS, E.E.; MATTHEWS, N.S. (1997). Magnetic resonance imaging of the brain of normal neonatal foals. Veterinary Radiology \& Ultrasound, v.38, n.2, p.102-111, Mar./Apr.

64. VAZQUEZ, J.M.; RIVERO, M.; GIL, F.; RAMIREZ, J.A.; RAMIREZ, G.; VILAR, J.M.; ARENCIBIA, A. (2001). Magnetic resonance imaging of two normal equine brains and their associated structures. Veterinary Record, v.148, n.8, p.229-232, Feb.

65. KANEPS, A.J.; KOBLIK, P.D.; FREEMAN, D.M.; POOL, R.R.; O'BRIEN, T.R. (1995). A comparison of radiography, computed tomography, and magnetic resonance imaging for the diagnosis of palmar process fractures in foals. Veterinary Radiology \& Ultrasound, v.36, n.6, p.467-477, Nov./Dec.

66. WIDMER, W.R.; BUCKWALTER, K.A.; FESSLER, J.F.; HILL, M.A.; VANSICKLE, D.C.; IVANCEVICH, S. (2000). Use of radiography, computed tomography and magnetic resonance imaging for evaluation of navicular syndrome in the horse. Veterinary Radiology \& Ultrasound, v.41, n.2, p.108-117, Mar./Apr.

67. VOGES, A.K.; ACKERMAN, N. (1995). MR evaluation of intra and extracranial extension of nasal adenocarcinoma in a dog and cat. Veterinary Radiology \& Ultrasound, v.36, n.3, p.102-109, May/June. 
68. ASPERIO, R.M.; MARZOLA, P.; ZIBELLINI, E.; VILLA, W.; SBARBATI, A.; OSCULATI, F.; ADDIS, F. (1999). Use of magnetic resonance imaging for diagnosis of a spinal tumor in a cat. Veterinary Radiology \& Ultrasound, v.40, n.3, p.267-270, May/June.

69. MORGAN, R.V.; RING, R.D.; WARD, D.A.; ADAMS, W.H. (1996). Magnetic resonance imaging of ocular and orbital disease in 5 dogs and a cat. Veterinary Radiology \& Ultrasound, v.37, n.3, p.185-192, May/June.

70. DENNIS, R. (2000). Use of magnetic resonance imaging for the investigation of orbital disease in small animals. Journal of Small Animal Practice, v.41, n.4, p.145-155, Apr.

71. MOORE, M.P.; GAVIN, P.R.; KRAFT, S.L.; DE HAAN, C.E.; LEATHERS, C.W.; DORN III, R.V. (1991). MR, CT, and clinical features from four dogs with nasal tumors involving the rostral cerebrum. Veterinary Radiology, v.32, n.1, p.19-25, Jan./Feb.

72. KIPPENES, H.; GAVIN, P.R.; BAGLEY, R.S.; SILVER, G.M.; TUCKER, R.L.; SANDE, R.D. (1999). Magnetic resonance imaging features of tumors of the spine and spinal cord in dogs. Veterinary Radiology \& Ultrasound, v.40, n.6, p.627-633, Nov./Dec.

73. KENT, M.; DE LAHUNTA, A.; TIDWELL, A.S. (2001). MR imaging findings in a dog with intravascular lymphoma in the brain. Veterinary Radiology \& Ultrasound, v.42, n.6, p.504-510, Nov./Dec.

74. THOMAS, W.B.; WHEELER, S.J.; KRAMER, R.; KORNEGAY, J.N. (1996). Magnetic resonance imaging features of primary brain tumors in dogs. Veterinary Radiology \& Ultrasound, v.37, n.1, p.20-27, Jan./Feb.

75. MARIANI, C.L.; CLEMMONS, R.M.; GRAHAM, J.P.; PHILLIPS, L.A.; CHRISMAN, C.L. (2001). Magnetic resonance imaging of spongy degeneration of the central nervous system in a labrador retriever. Veterinary Radiology \& Ultrasound, v.42, n.4, p.285-290, July/Aug.

76. LIPSITZ, D.; LEVITSKI, R.E.; CHAUVET, A.E.; BERRY, W.L. (2001). Magnetic resonance imaging features of cervical stenotic myelopathy in 21 dogs. Veterinary Radiology \& Ultrasound, v.42, n.1, p.20-27, Jan./Feb.

77. DEHAAN, J.J.; SHELTON, S.B.; ACKERMAN, N. (1993). Magnetic resonance imaging in the diagnosis of degenerative lumbosacral stenosis in four dogs. Veterinary Surgery, v.22, n.1, p.1-4, Jan./Feb. 
78. JONES, J.C.; BANFIELD, C.M.; WARD, D.L. (2000). Association between postoperative outcome and results of magnetic resonance imaging and computed tomography in working dogs with degenerative lumbosacral stenosis. Journal of the American Veterinary Medical Association, v.216, n.11, p.1769-1774, June.

79. GONZELO-ORDEN, J.M.; ALTÓNAGA, J.R.; ASUNCIÓN-ORDEN, M.; GONZALO, J.M. (2000). Magnetic resonance, computed tomographic and radiologic findings in a dog with discospondylitis. Veterinary Radiology \& Ultrasound, v.41, n.2, p.142-144, Mar./Apr.

80. KRAFT, S.L.; MUSSMAN, J.M.; SMITH, T.; BILLER, D.S.; HOSKINSON, J.J. (1998). Magnetic resonance imaging of presumptive lumbosacral discospondylitis in a dog. Veterinary Radiology \& Ultrasound, v.39, n.1, p.9-14, Jan./Feb.

81. DVIR, E.; KIRBERGER, R.M.; TERBLANCHE, A.G. (2000). Magnetic resonance imaging of otitis media in a dog. Veterinary Radiology \& Ultrasound, v.41, n.1, p.46-49, Jan./Feb.

82. GAROSI, L.S.; LAMB, C.R.; TARGETT, M.P. (1998). MRI findings in a dog with otitis media and suspected otitis interna. Veterinary Record, v.146, n.17, p.501-502, Apr.

83. ROMAGNANO, A.; SHIROMA, J.T.; HEARD, D.J.; JOHNSON, R.D.; SCHIERING, M.R.; MLADINICH, C.R.J. (1996). Magnetic resonance imaging of the brain and coelomic cavity of the domestic pigeon. Veterinary Radiology \& Ultrasound, v.37, n.6, p.431-440, Nov./Dec.

84. PYE, G.W.; BENNET, R.A.; NEWELL, S.M.; KINDRED, J.; JOHNS, R. (2000). Magnetic resonance imaging in psittacine birds with chronic sinusitis. Journal of Avian Medicine and Surgery, v.14, n.4, p.243-256.

85. VERHOYE, M.; VAN DER LINDEN, A.; VAN AUDEKERKE, J.; SIJBERS, J.; EENS, M.; BALTHAZART, J. (1998). Imaging birds in a bird cage: invivo, FSE 3D MRI of bird brain. Magnetic Resonance Materials in Biology, Physics and Medicine, v.6, n.1, p.22-27.

86. MORGAN, R.V.; DONNELL, R.L.; DANIEL, G.B. (1994). Magnetic resonance imaging of the normal eye and orbit of a screech owl (Otus asio). Veterinary Radiology \& Ultrasound, v.35, n.5, p.362-367, Sept./Oct.

87. BARTELS, T.; BRINKMEIER, J.; PORTMANN, S.; BAULAIN, U.; ZINKE, A.; KRAUTWALD-JUNGHANNS, M.E.; BOOS, A.; WOLF, P.; KUMMERFELD, N. (2001). Magnetic resonance imaging of intracranial tissue accumulations in domestic ducks (Anas platyrynchos f. dom.) with feather crests. Veterinary Radiology \& Ultrasound, v.42, n.3, p.254-258, May/June. 
88. PEPPERBERG, I.M.; HOWELL, K.S.; BANTA, P.A.; PATTERSON, D.K.; MEISTER, M. (1998). Measurement of grey parrot (Psittacus erithacus) trachea via magnetic resonance imaging, dissection, and electron beam computed tomography. Journal of Morphology, v.238, p.81-91.

89. CZISCH , M.; COPPACK, T.; BERTHOLD, P.; AUER, D.P. (2001). In vivo magnetic resonance imaging of the reproductive organs in a passarine bird species. Journal of Avian Biology, v.32, n.3, p.278-281.

90. MANGINI, P.R. (1998). Captura e contenção de animais selvagens. /Apostila do III Curso Nacional de Biologia da Conservação e Manejo da Vida Silvestre/

91. CRUZ, M.L. Anestesia em aves e répteis. Botucatu. /Apostila FMVZ - UNESP/

92. MASSONE, F. (1988). Anestesiologia veterinária. Rio de Janeiro, Guanabara Koogan. p.1-17: Considerações gerais.

93. NICOLAU, A.A.; SPINOSA, H.S. (1997). Considerações sobre imobilização e anestesia em aves. Revista do Instituto de Ciências da Saúde, v.15, n.2, p.73-78, jul./dez.

94. HARRISON, G.J. (1986). Anesthesiology. In: HARRISON, G.J.; HARRISON, L.R. Clinical avian medicine and surgery including aviculture. Philadelphia, W.B. Saunders. p.549-559.

95. HARRISON, G.J. (1993). Anaesthesia and surgery. Proceedings of the 1993 European Conference on Avian Medicine \& Surgery, p.86-119, Mar.

96. STEINER JR., C.V.; DAVIS, R.B. (1985). Patologia de las aves enjauladas: temas seleccionados. Zaragoza, Acribia. p.125-131: Anestesia de aves enjauladas.

97. MASSONE, F. (1988). Anestesiologia veterinária. Rio de Janeiro, Guanabara Koogan. p.90-94: Neuroleptoanalgesia e anestesia dissociativa.

98. MASSONE, F. (1988). Anestesiologia veterinária. Rio de Janeiro, Guanabara Koogan. p.95-101: Miorrelaxantes.

99. COLES, B.H. (1985). Avian medicine and surgery. Oxford, Library of Veterinary Practice Blackwell Scientific Publications. p.102-121: Anaesthesia.

100.ROSSKOPF JR., W.J.; WOERPEL, R.W. (1996). Practical anesthesia administration. In: ROSSKOPF JR., W.J.; WOERPEL, R.W. Diseases of cage and aviary birds. Baltimore, Williams \& Wilkins. p.664-671. 
101.SEDGWICK, C.J. (1986). Inhalation anesthesia for captive wild mammals, birds, and reptiles. In: FOWLER, M.E. Zoo \& wild animal medicine. Philadelphia, W.B. Saunders. p.51-56.

102.MASSONE, F. (1988). Anestesiologia veterinária. Rio de Janeiro, Guanabara Koogan. 188-197: Anestesias para cesarianas.

103.COLLAR, N.J. (1997). Order psittaciformes - family psittacidae (Parrots). In: DEL HOYO, J.; ELLIOTT, A.; SARGATAL, J. Handbook of the birds of the world. Barcelona, Lynx. v.4, p.280-479.

104.RUSCHI, A. (1981). Aves do Brasil: chaves artificiais e analíticas. São Paulo, Rios. v.2, p.17-28: Prancha 1.

105.FONSECA, A. (1994). Biologia. São Paulo, Ática. p.11-15: Classificação dos seres vivos.

106.PETERSON, J.H. Aratinga leucophthalmus leucophthalmus. Lexicon Foundation Dutch Parrot Refuge. Disponível em: $<$ http://www.papegaai.org/lexicon/16088.htm> Acesso em: 09 jul. 2001.

107.LUDDERS, J.W.; SEAMAN, G.C.; ERB, H.N. (1995). Inhalant anesthetics and inspired oxygen: implications for anesthesia in birds. Journal of the American Animal Hospital Association, v.31, n.1, p.38-41.

108.RUPLEY, A.E. (1999). Manual de clínica aviária. São Paulo, Roca. p.559-560: Apêndice 5: Anatomia visceral das aves.

109.SEXAGEM de aves: ágil e acessível. Disponível em: $<$ http://www.tecsa.com.br/lado sexagem.html> Acesso em: 16 fev. 2001.

110.LUMEIJ, J.T. (1994). Nephrology. In: RITCHIE, B.W.; HARRISON, G.J.; HARRISON, L.R. Avian medicine: principles and application. Florida, Wingers. p.538-555.

111.RUPLEY, A.E. (1999). Manual de clínica aviária. São Paulo, Roca. p.535-547: Formulário.

112.FÁVARO, T. (2002). Pombos. Disponível em: $<$ http://www.estado.estadão.com.br/suplementos/agri/2002/04/10agri005.ht ml> Acesso em: 30 maio. 2002.

113.RUPLEY, A.E. (1999). Manual de clínica aviária. São Paulo, Roca. p.431-458: Obtenção de imagens.

114.GRIFFITHS, R.; DOUBLE, M.C.; ORR, K.; DAWSON, R.J.G. (1998). A DNA test to sex most birds. Short communication. Molecular Ecology, v.7, p.1071-1075. 
115.PIRES, L. Reação em cadeia de polimerase (PCR): aplicações clínicas em neurologia. Disponível em: $<$ http://www.neurologia.ufjf.br/artigos/nol_num_02_polimerase.htm> Acesso em: 30 ago. 2001.

116.ANILHA. In: GLOSSÁRIO. Disponível em: $<$ http://www.bibvirt.futuro.usp.br/especiais/aves_no_campus/glossario.html $>$ Acesso em: 09 maio 2002.

117.COBERTEIRAS. In: GLOSSÁRIO. Disponível em: $<$ http://www.bibvirt.futuro.usp.br/especiais/aves_no_campus/glossario.html > Acesso em: 09 maio 2002.

118.HIPÓXIA. In: ROSSI, R.; GOLDIM, J.R.; FRANCISCONI, C.F. (1999). Glossário de termos científicos para elaboração do consentimento informado. Revista de Medicina ATM, v.19, n.1, p.304309.

119.POLIMORFISMO. In: GLOSSÁRIO. Disponível em: $<$ http://www.bibvirt.futuro.usp.br/especiais/aves_no_campus/glossario.html $>$ Acesso em: 09 maio 2002.

120.A EMA (Rhea americana americana) - sua criação e sua biologia. Disponível em: <http://www.antares.i8.com/VENDAS.html> Acesso em: 07 ago. 2002.

121.DOCA, R.H. (1987). Objetivo: sistema de métodos de aprendizagem. São Paulo, CERED. 67-78: Fenômenos ondulatórios. 
Anexo 1 Comissão de Ética em Experimentação Animal (CEEA) do Instituto de Ciências Biomédicas da Universidade de São Paulo (ICB/USP) 
Anexo 2 Licença IBAMA, Processo número 02027. 008093/01-93 


\section{Anexo 3 Sexagem de Aves pelo Exame de Polimorfismo de DNA}

\section{Coleta de Sangue}

A coleta de sangue para a realização do exame de polimorfismo de DNA foi feita nas instalações do CETAS de São Carlos. Os animais foram contidos, e então realizada a anti-sepsia da região inferior da asa.

Com o auxílio de uma pequena lanceta, a qual fazia parte do $\mathrm{kit}^{5}$ para coleta de sangue (Figura 35), foi realizada uma pequena perfuração na veia braquial da asa da ave, e um papel filtro (também pertencente ao kit de coleta), foi encostado neste local, para que absorvesse pequena quantidade de sangue. Cada papel filtro foi identificado com a espécie e o número de anilha do animal. Após esse procedimento, foi feita uma suave compressão no local perfurado, para efetuar a hemostasia. $\mathrm{O}$ sangue coletado foi então enviado ao CITOCEL - Laboratório em Genética, para a realização da análise de DNA desses animais e sua posterior sexagem.

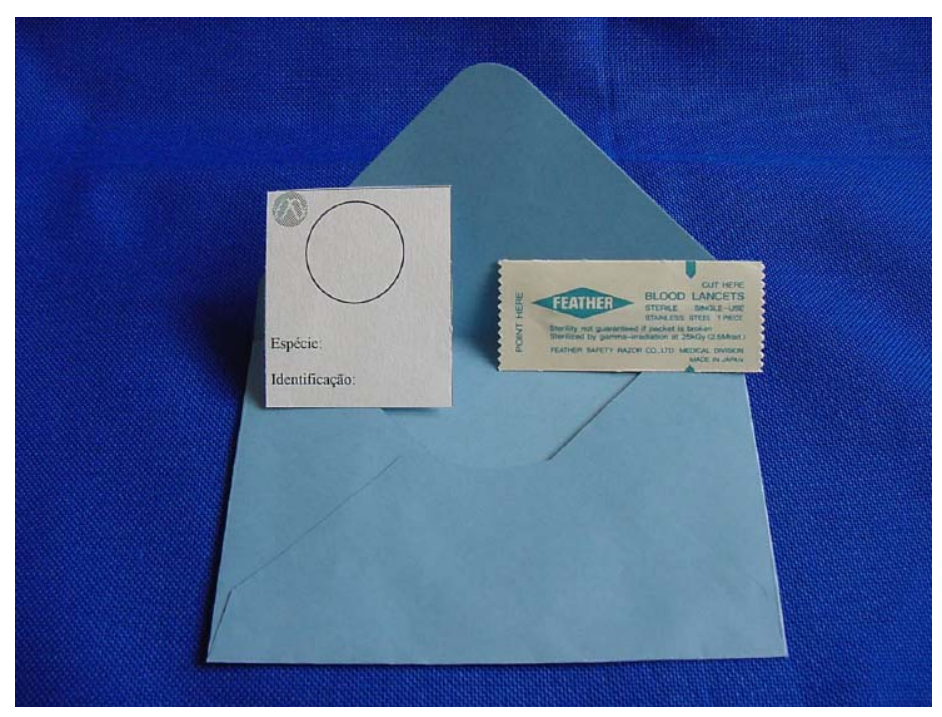

Figura 35 - Kit para a coleta de sangue composto de lanceta e papel filtro. 


\section{Exame de Polimorfismo de DNA}

Normalmente, um indivíduo herda um conjunto completo de genes do pai e outro da mãe. Esses genes estão dispostos em estruturas conhecidas como cromossomos. O número, o tamanho e a forma dos cromossomos variam de espécie para espécie, porém, na grande maioria das espécies, os cromossomos ocorrem em pares. Em um desses pares cromossômicos se encontram os genes que determinam o sexo, sendo assim chamados de cromossomos sexuais. Dessa forma, a chave para a determinação do sexo é a diferença encontrada nos cromossomos sexuais. Em mamíferos, os dois cromossomos que constituem o par sexual dos machos são denominados cromossomos X e Y. Nas fêmeas de mamíferos, o par de cromossomos sexuais é constituído por dois cromossomos X. Desse modo, nos mamíferos, os machos são XY e as fêmeas são XX. Nas aves, os cromossomos sexuais recebem nomes diferentes e sua relação com o sexo é oposta à dos mamíferos: as aves macho são ZZ e as fêmeas, ZW ${ }^{[17]}$.

$\mathrm{Na}$ última década, a descrição dos genes CHD (chromo-helicase-DNAbinding), genes localizados nos cromossomos sexuais da maioria das aves, fez com que a tecnologia do DNA aplicada a esses animais viesse a ser amplamente utilizada na identificação dos sexos dos indivíduos. Esse gene apresenta formas diferentes (o que é chamado de polimorfismo) entre os dois tipos de cromossomos ${ }^{[17]}$. Assim, aves com dois cromossomos Z, ou seja, machos, vão apresentar duas cópias iguais do gene CHD, também chamado de CHD-Z. Da mesma forma, aves fêmeas, com cromossomos sexuais diferentes $\mathrm{Z}$ e W, irão apresentar uma cópia do gene CHD-Z e outra do gene CHD-W. Como se pode observar, o gene CHD-Z está presente em ambos os sexos, enquanto que o CHD-W está presente apenas nas fêmeas ${ }^{[17,114]}$.

Ao se aplicarem técnicas de biologia molecular em amostras biológicas de aves, pode-se determinar quais os tipos do gene CHD que elas apresentam. Inicialmente, o DNA é extraído dessas amostras (uma gota de sangue é suficiente), e então é submetido a uma técnica denominada PCR (do inglês polymerase chain reaction ou reação em cadeia da polimerase). Com essa metodologia são obtidos fragmentos do DNA das aves, os quais correspondem aos genes CHD presentes, que

\footnotetext{
${ }^{5}$ Doação feita pelo CITOCEL Laboratório em Genética - Porto Alegre/RS.
} 
dependendo do tipo do gene, apresentam tamanhos diferentes ${ }^{[17]}$. A molécula de DNA é bastante estável, mantendo as ligações adenina - timina e guanina - citosina por meio de pontes de hidrogênio, mas quando, na técnica PCR, é aquecida a $94^{\circ} \mathrm{C}$, as pontes se rompem e separam-se as duas hélices. Quando se resfria a molécula (30 a $65^{\circ} \mathrm{C}$ ), a mesma volta a se ligar. Nesta fase, há acoplamento dos primers (seqüência de 20 a 30 nucleotídeos que vão se ligar a cada uma das hélices delimitando o fragmento a ser copiado) nos locais pré-determinados. Devido ao resfriamento, como já dito, a molécula de DNA tende a se ligar novamente (formação de dupla hélice), mas como existe no meio grande quantidade de primers, estes acoplarão nos sítios específicos, constituindo assim o local para iniciar o seqüenciamento dos nucleotídeos. A solução, então, é reaquecida a $72^{\circ} \mathrm{C}$, temperatura ideal para a atuação da taq polimerase, que a partir do primer, inicia a adição do nucleotídeo correspondente no seqüenciamento, criando moléculas complementares. Após este processo, o fragmento de DNA foi duplicado. Essa seqüência poderá ser repetida várias vezes e em cada ciclo haverá duplicação do DNA. No final de cinco horas, haverá milhares de cópias da molécula inicial ${ }^{[115]}$.

Os fragmentos de DNA são, então, aplicados em um suporte sólido (gel) e submetidos a forte corrente elétrica (eletroforese). As moléculas de DNA são carregadas, migrando em função da corrente aplicada; as cópias de diferentes tamanhos se separam, enquanto as idênticas migram para a mesma posição. Após o tempo necessário para a separação, o DNA é corado e se pode visualizar o gene na forma de uma banda ${ }^{[17]}$. Dessa forma, os machos irão apresentar uma única banda, pois possuem duas cópias do gene CHD-Z, enquanto as fêmeas apresentarão duas bandas, porque possuem uma cópia do gene CHD-Z e outra do gene CHD-W, conforme a Figura $36^{[17,114]}$. 


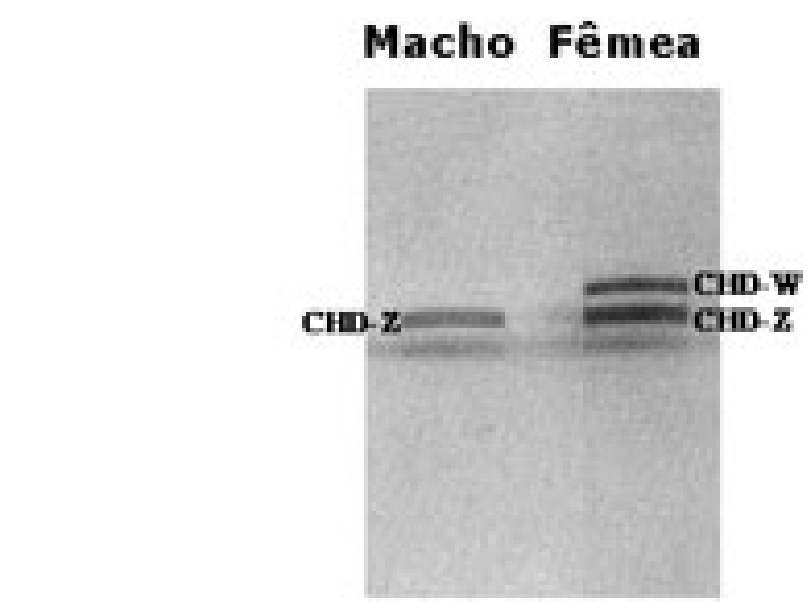

Figura 36 - Demonstração dos genes em forma de bandas no gel ${ }^{[17]}$.

Testes realizados com essa metodologia demonstraram sua aplicabilidade em praticamente todas as espécies de aves ${ }^{[17]}$. 


\section{Anexo 4 Glossário}

Anilha: anel de uma liga metálica leve que é adaptado ao tarso-metatarso das aves. No Brasil, as anilhas são fornecidas pelo Centro de Pesquisas para a Conservação das Aves Silvestres (CEMAVE) e possuem a inscrição de um número de 5 algarismos precedido por uma letra $(\mathrm{C}, \mathrm{D}, \mathrm{E}, \mathrm{G}, \mathrm{H}$..., Z). A letra corresponde ao diâmetro da anilha, que deve adaptar-se adequadamente ao tarso-metatarso da ave. Nas anilhas de maior diâmetro (H a Z) existe na sua face externa a inscrição AVISE CEMAVE C.P. 34 Brasília D.F.; naquelas de menor diâmetro (C a G) tal inscrição encontra-se na sua face interna. Neste último caso deve ser lembrado o código do CEMAVE, letra + número de 5 algarismos e, sem retirar a anilha da ave, principalmente se ela estiver viva, avisar o CEMAVE. Esta informação é muito importante para os estudos de migrações de aves, pois é através destas recuperações que são estabelecidos os deslocamentos e as rotas migratórias das espécies. Estes aspectos fornecem, também, subsídios para a conservação e manejo das aves silvestres ${ }^{[116]}$.

Coberteiras ou tectrizes: penas que recobrem dorsal e ventralmente as penas de vôo, rêmiges e rectrizes. São denominadas de coberteiras superiores e inferiores, respectivamente; entre elas distinguem-se as coberteiras maiores, médias e menores [117]

Dimorfismo sexual: fenômeno comum em insetos e aves em que, na mesma espécie, a fêmea difere do macho em tamanho, cor etc. ${ }^{[9]}$.

Epidídimo: é uma estrutura alongada e fusiforme, intimamente inserida ao longo de todo o comprimento da borda dorsomedial do testículo ${ }^{[28]}$.

Gônada: glândula sexual que produz os gametas e segrega os hormônios. O testículo é a gônada masculina e o ovário, a feminina ${ }^{[16]}$.

Hipóxia: baixo nível de oxigênio no sangue ${ }^{[118]}$. 
Megadiversidade: envolve a diversidade biológica (espécies da fauna e da flora) e a diversidade de ecossistemas (habitats dessas espécies) ${ }^{[1]}$.

Polimorfismo: presença de duas ou mais formas, com padrões cromáticos distintos, na mesma população de uma espécie, independente de sexo, idade, estação do ano ou raça geográfica ${ }^{[119]}$.

Precessão: é o movimento induzido por um campo magnético estático, onde os momentos magnéticos microscópicos giram em torno da orientação desse campo, tal como um pião gira em torno do eixo normal do campo gravitacional da Terra ${ }^{[38]}$.

Ratitas: aves que não voam e que em geral possuem grande porte e capacidade de corrida, como por exemplo, as emas e os avestruzes ${ }^{[120]}$.

Ressonância: é o fenômeno que ocorre quando um sistema recebe energia periodicamente com uma freqüência igual a uma de suas freqüências próprias de vibração ${ }^{[121]}$.

Sinsacro: fusão de 10 a 23 vértebras torácicas, lombares, sacrais e urosacrais ${ }^{[28]}$.

Spin nuclear ou momento angular intrínseco do núcleo: movimento de rotação do núcleo em torno de um de seus eixos ${ }^{[36]}$.

Urodeo: juntamente com o coprodeo e o proctodeo, constituem os compartimentos da cloaca das aves ${ }^{[28]}$. 